\title{
Muslim Education and Communal Conflict in Colonial Bengal: British Policies and Muslim Responses from 1854 to 1947
}

\author{
Nilanjana Paul
}

Follow this and additional works at: https://researchrepository.wvu.edu/etd

\section{Recommended Citation}

Paul, Nilanjana, "Muslim Education and Communal Conflict in Colonial Bengal: British Policies and Muslim Responses from 1854 to 1947" (2016). Graduate Theses, Dissertations, and Problem Reports. 6390. https://researchrepository.wvu.edu/etd/6390

This Dissertation is protected by copyright and/or related rights. It has been brought to you by the The Research Repository @ WVU with permission from the rights-holder(s). You are free to use this Dissertation in any way that is permitted by the copyright and related rights legislation that applies to your use. For other uses you must obtain permission from the rights-holder(s) directly, unless additional rights are indicated by a Creative Commons license in the record and/ or on the work itself. This Dissertation has been accepted for inclusion in WVU Graduate Theses, Dissertations, and Problem Reports collection by an authorized administrator of The Research Repository @ WVU. For more information, please contact researchrepository@mail.wvu.edu. 
Muslim Education and Communal Conflict in Colonial Bengal: British Policies and Muslim Responses from 1854 to 1947

\author{
Nilanjana Paul
}

This dissertation submitted to the Eberly College of Arts and Sciences at West Virginia University

\begin{abstract}
in partial fulfillment of the requirements for the degree of
Doctor of Philosophy in

History/ Colonial India
\end{abstract}

\author{
Mark Tauger, Ph.D., Committee Chair \\ Joseph Hodge, Ph.D., Committee Chair \\ Robert Maxon, Ph.D. \\ Katherine Aaslestad, Ph.D. \\ Suchetana Chattopadhyay, Ph.D. \\ Department of History
}

Morgantown, West Virginia

2016

Keywords: Muslims, Colonial Education, India

Copyright 2016 Nilanjana Paul 


\begin{abstract}
Muslim Education and Communal Conflict in Colonial Bengal: British Policies and Muslim Responses from 1854 to 1947
\end{abstract}

Nilanjana Paul

This dissertation examines the development of Muslim education under British rule in Bengal. In the first part of the dissertation, I analyze why Muslims were unable to progress under colonial rule and examine some of the factors that helped to change their view towards the British from the late nineteenth century. The role played by Nawab Bahadur Abdul Latif in improving Muslim education is used here as a case study to show how elite Muslims deprived their co-religionists of Western education in order to reduce competition in the field of employment. In the second part of the dissertation, I study the transition in British policies with regard to Muslim education from the nineteenth to the twentieth century. It also analyzes the debates and responses within the Muslim community over the reforms introduced by the colonial state. Finally, the dissertation evaluates the role played by Fazlul Huq in improving the educational situation of Muslims towards the end of colonial rule and thus brings to light the conflicts over educational reforms, which eventually strengthened the demand for a separate nation. 


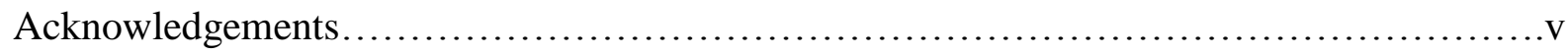

List of Foreign Terms and Definitions.................................................. vi

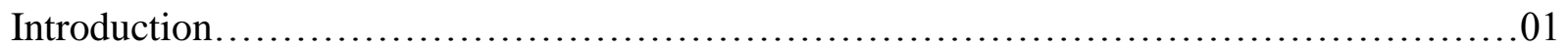

Significance of the Dissertation to the existing literature.............................. 02

Methodology and Analysis of the Sources..........................................

Organization of the chapters...................................................... 10

Chapter 1: A Brief History of Pre-colonial and Colonial Bengal

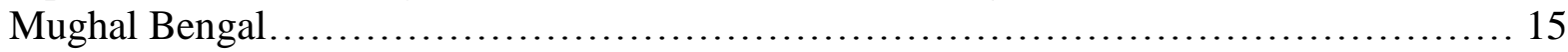

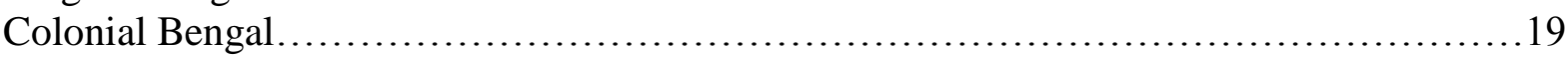

Chapter 2: Public Debates on the Wood's Despatch and the Spread of English education in Nineteenth century Bengal

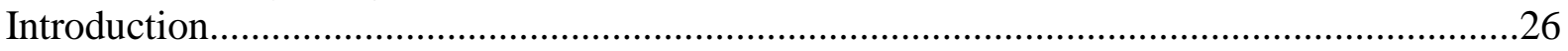

East India Company and Education.................................................... 28

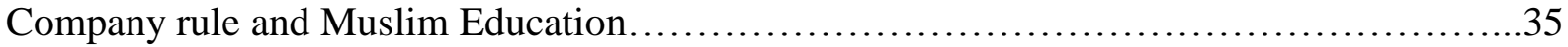

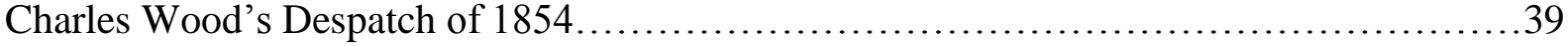

Immediate impact of the Wood's Despatch.............................................. 43

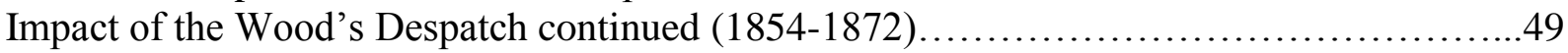

Wood's Despatch and Muslim Education..............................................5

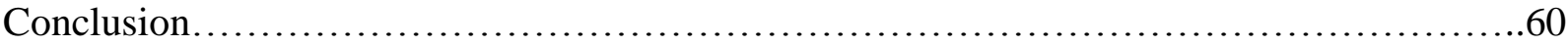

Chapter 3: Nawab Bahadur Abdul Latif and the Changing Muslim Approach towards Western Education

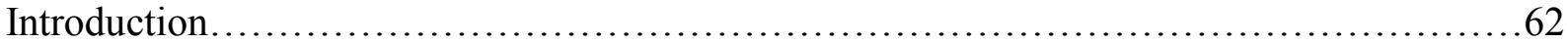

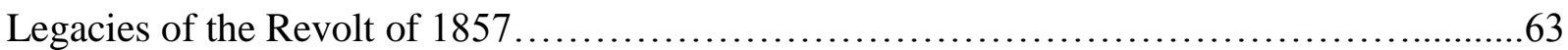

The Changing approach towards British rule and Western knowledge.......................65

Nawab Bahadur Abdul Latif: Contributions and Criticisms.................................70

Muslim education in the late nineteenth century ..................................... 78

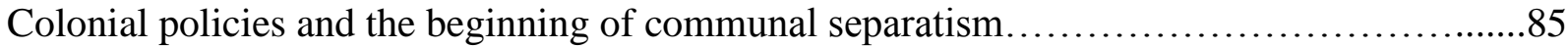

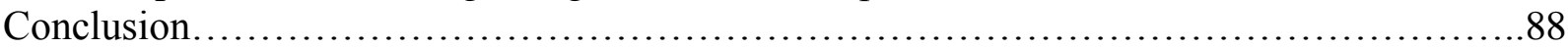

Chapter 4: Partition, Swadeshi, War, and Muslim Education, 1905-1921

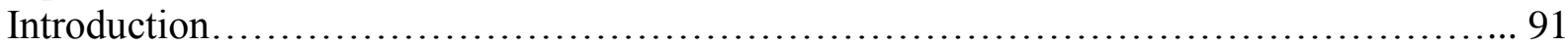

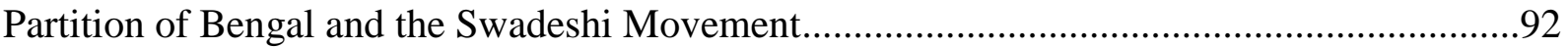

The Crucial Years

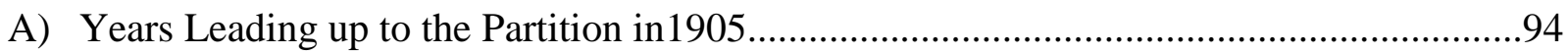

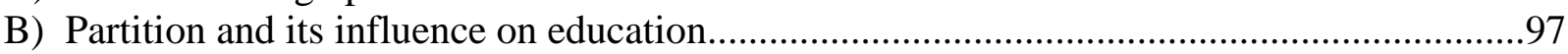

C) Partition, Swadeshi, and Muslim Education................................................................102

World War I and the establishment of the Dhaka University in $1921 \ldots \ldots \ldots \ldots \ldots \ldots \ldots \ldots \ldots \ldots \ldots . . .118$ 
Conclusion.

Chapter 5: Muslim education during the period of political turmoil, 1921-1935

Introduction 128

1. The last stage of Hindu-Muslim unity: from World War I to the Bengal Pact of 1923

A. Impact of Montague-Chelmsford reforms on Muslim education........................................130

B. Khilafat and the Non-Cooperation movements................................................................ 140

2. The period of declining Hindu-Muslim unity

A. The Bengal Pact of 1923 and its impact on Muslim education............................. 146

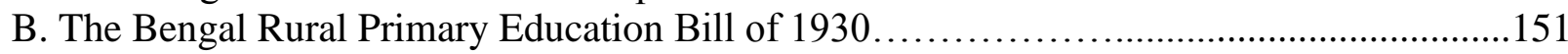

3. The increase in animosity between Hindus and Muslims: from the Civil Disobedience

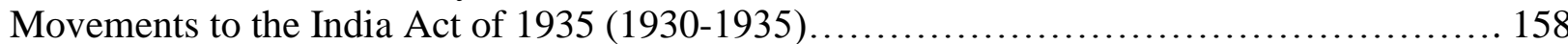

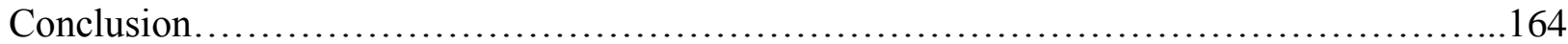

Chapter 6: Towards independence: Muslim education during the final stages of colonial rule, $1935-1947$

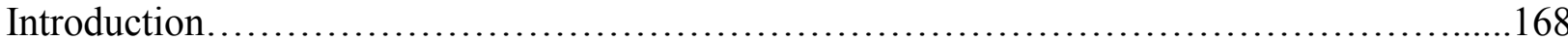

1. The political crisis of the late 1930s and the status of Muslim education

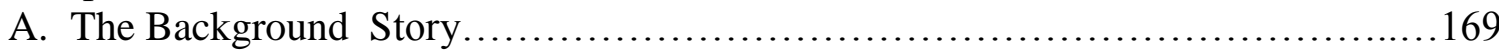

B. The India Act of 1935 and Muslim education......................................173

2. Fazlul Huq: The Politician and the Educationist

A. The Politician.................................................................. 177

B. Fazlul Huq as the Education Minister........................................ 178

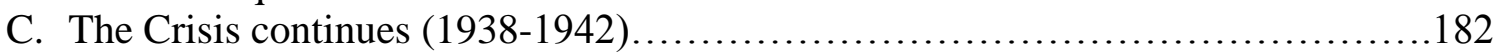

3. The Last Phase: Partition Politics and Muslim Education............................................191

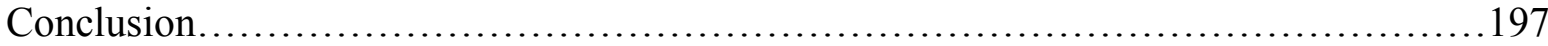

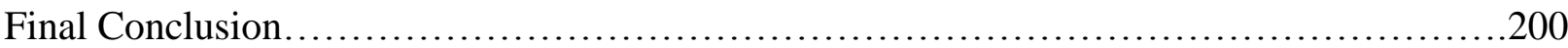

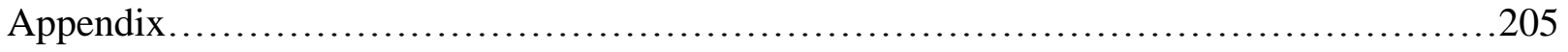

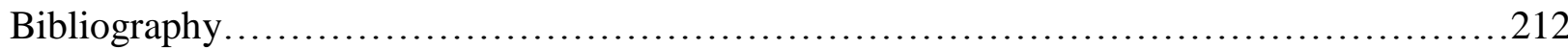




\section{Acknowledgements}

In the course of pursuing this $\mathrm{PhD}$ and writing the dissertation, I am indebted to my advisers, Dr. Joseph Hodge and Dr. Mark Tauger for their guidance and meticulous reading of the chapters, which helped me to complete this dissertation. Dr. Suchetana Chattopadhyay, my external supervisor, has also helped me extensively during my archival research in Kolkata, New Delhi, and London. Her guidance and friendship has assisted me to understand the complexities of the topic. Professors Robert Maxon, Elizabeth Fones-Wolf, and Katherine Aaslestad offered valuable advice and helped me to adjust to this different academic routine in the United States. Lastly, I am grateful to Dr. Samuel White who provided the much needed financial support during the last year of my graduate school.

The kindness of my friends and family members in India, Great Britain, and North America has helped me to survive this period of joy and struggle. I am truly grateful to Amrita, Abhishek, Anindita, Aparna aunty, Ayushman, Brandon, Bahni, Bonnie, Cyprien, Debabrata, Mrs. Eva Tauger, Gobindo, Indrila, Indrajit uncle, Isaac, Ipsita, Jake, Jeff, Jenny, Justin, Joe, Kingsuk, Krystal, Lindsey, Manabika, Manju aunty, Megan, Martha, Nivedita, Nina, Pallabi, Paul, Prakriti, Ratnabali masi, Signe, Souvik, Sujoy, Somnath, Tamba, and Titas for their concern, friendship, and love. Finally, I dedicate this dissertation to my parents to whom I am indebted in ways to numerous to account for. 


\title{
List of Foreign Terms and Definitions
}

\author{
Ahimsa - Non- Violence \\ Andolan - Movement \\ Anjumans - Private associations \\ Ashraf - Elite Muslims \\ Atrap - Lower caste Muslims \\ Banians - Business agents \\ Babus - Upper Middle class intellectuals \\ Bhadraloks - Well mannered educated Bengalis mostly referred to elite Hindus \\ Kafirs - Non-believers \\ Krishak - Peasants \\ Madrassah - Schools which provide education in Koran, Arabic, Persian, and the Islamic Law \\ Maktab - Primary school for Muslims \\ Maulvis - Muslim religious teachers \\ Muffasils - Hinterland \\ Mullas - Islamic clerics \\ Muallim Schools - Training schools for Maulvis \\ Nawab - King \\ Pathsalas - Indigenous elementary schools \\ Pir - A Persian word, which means a spiritual guide \\ Rashtra - Nation \\ Rishis - Saints
}


Ryots - Peasants

Sati- Widow burning

Satyagraha - Passive Resistance

Sepoys - Soldiers

Swadeshi - Nationalist Movement

Swaraj - Independence

Zamindars - Landlords

Zillah - Districts 


\section{Introduction}

My dissertation explores the development of Muslim education in a portion of British India from 1854 to 1947 . It specifically studies the province of Bengal, which had the second largest Muslim population in colonial India. The study investigates and evaluates the Muslim educational institutions that developed in the high colonial period after the Charles Wood's Despatch of 1854 and examines the role played by Nawab Bahadur Abdul Latif (Professor of English at the Calcutta Madrassah) and Fazlul Huq (Education Minister of Bengal) in improving education among the Muslim community. Lastly, the study analyzes the complicated problems associated with colonial education policies and evaluates the impact of these policies on HinduMuslim relations in Bengal, using a wide variety of archival, primary, and secondary sources.

The dissertation demonstrates that the British introduced a system of education based on the principles of liberalism through the Despatch of 1854. As a result, educational institutions depended on both government and private support for their sustenance. The system of grants-inaid required students to pay fees for their education and grants were only given to institutions that maintained the policy of religious neutrality. The introduction of a more public - private form of education adversely affected the position of Muslims as they were dependent on the state for education before the coming of the British. Moreover, English became the most important language under colonial rule. But Muslims were used to the study of Arabic and Persian. The knowledge of Arabic and Persian was necessary for being a liberal Muslim. My dissertation shows that middle class Hindus learned English as it was necessary to secure government jobs. However, the dissertation also brings to light that there was a huge debate within the Hindu community over the benefits of Western education through the medium of English. At the same 
time, for Muslims, the failure to adjust to the new system of education resulted in the development of an unequal society. ${ }^{1}$

The initial failure motivated elite Muslims to collaborate with the British towards the second half of the nineteenth century and in return demand separate educational institutions for Muslims. In this context, my dissertation reveals the heterogeneous nature of the Muslim community. A section of the Muslim community opposed separate educational institutions as it complicated the communal situation of the province. But Muslim intellectuals also denied English education to the rural Muslims, similar to elite Hindus, as it increased competition in the field of education and employment. In addition to the rural masses, Hindus opposed the special favors and constitutional safeguards offered by the colonial state to Muslims. My work brings to light the complexities within the Muslim community with regard to colonial education and separate educational institutions. Finally, the dissertation shows how separate educational institutions, which in reality were a response to the limited opportunities offered by the colonial state, strengthened the division between Hindus and Muslims. The emergence of a communalized society mobilized Muslim opinion to support a separate nation, where they didn't have to compete with Hindus for jobs and were guaranteed inexpensive education of their choice.

\section{Significance of the Dissertation to the existing secondary literature}

The existing literature on Muslim education has been restricted to the late nineteenth century. There is a gap in the literature on Muslim education after 1900. What follows is a brief summary of the most significant works on colonial and Muslim education in India. It shows that

\footnotetext{
${ }^{1}$ Religious Neutrality: The British government did not directly introduce the teaching of Christianity in any schools that it sponsored. They were afraid that it might provoke hostility. The Wood's Despatch only gave grants to schools that provided secular education. The government did not support maktabs and madrassahs, which were centers of Arabic and Persian learning in pre-colonial Bengal.
} 
my dissertation brings to light some of the most important educational reforms that influenced the progress of Muslim education and reveals how these policies strengthened the demand for separate educational institutions. My study uses educational policies to show the impact of the reforms on the Muslim community and how it aggravated the communal situation of the province. In-depth analyses of the educational institutions established to improve Muslim education reveals how these institutions suffered from financial crisis and were only able to influence a section of the Muslim community. The next few paragraphs analyze some of the works on colonial education briefly to show that the connection between Muslim education communal conflict have been mostly overlooked or dealt very briefly by scholars

Three scholars, Srikumar Acharya, Gauri Viswanathan, and Parna Sengupta, have discussed the spread of English education in Bengal in the first half of the nineteenth century They have examined some of the changes introduced by the Wood's Despatch in 1854 and its effect in producing a stratified society. These authors have however overlooked the problems associated with the spread of Muslim education as a result of this despatch. ${ }^{2}$

Scholars focusing on colonial education like Shibaji Bandopadhyay argued that according to the British, Western education modernized Indians. He analyzed James Mill's “A History of British India” to show that according to Mill, Hindus made no important contributions to the literature or culture of India. To Mill, Western education civilized Indians. In his analysis, Bandopadhyay showed that by introducing English education, the British expanded their power in India. At the same time, he also analyzed the responses of Hindu intellectuals to modern Western education. For example, the famous Bengali poet Rabindranath Tagore believed that

\footnotetext{
${ }^{2}$ Gauri Viswanathan, Masks of Conquest: Literary Study and British rule in India (India: Oxford University Press, 1989); Parna Sengupta, Pedagogy for Religion: Missionary Education and the Self Fashioning of Hindus and Muslims in Bengal (Berkeley: University of California Press, 2011); Srikumar Acharya, The Changing Pattern of Education in early Nineteenth century Bengal (Kolkata: Punthi Pustak,1992); Shibaji Bandopadhyay, Gopal Rakhal Dandosamas: Uponibeshbad o Bangla Sishu Sahitya (Kolkata: Papyrus, 1991).
} 
English education did not help in educational growth. Indians were just memorizing facts instead of acquiring proper knowledge. Through his work, Bandopadhyay analyzed the middle class subject formation under colonial rule. Tithi Bhattacharya in her work examined the relation between education and middle class identity and argued that elite Hindus dominated Western education as they could pay for the expensive education. Both Bandopadhyay and Bhattacharya have discussed the spread of education among Hindus but have briefly dealt with the problems associated with the spread of education among Muslims. Jaya Chatterjee, in her analysis, argued that bhadraloks (well mannered educated Bengalis usually referred to elite Hindus) used Western education for advancement under colonial rule. But the newly formed bhabdaloks were divided on the basis of wealth, employment, and caste hierarchy. Chatterjee in her work analyzes why bhadraloks became extremely communal during colonial rule. However, she does not address the role of the colonial state in creating the divide between Hindus and Muslims. ${ }^{3}$

Historians studying the Muslim community in colonial Bengal, including Sufia Ahmed, have provided a chronological account of the several reforms introduced by the colonial state. Her work has not discussed the major problems associated with the reforms and their impact on the Muslim community. M. Fazlur Rahman argued that the indigenous system of education before colonial rule depended on religious trusts and students were not required to pay any fees. But with the introduction of colonial rule, Muslim families lost their sources of income because of the introduction of the Permanent Settlement in 1793 by Lord Cornwallis. The Permanent Settlement of 1793 secured the rights of the Hindu rentier class who acted as the absentee landlords. The rentier class extracted huge taxes from the Muslim peasants and did not

\footnotetext{
${ }^{3}$ Tithi Bhattachrya, Sentinels of Culture: Class, Education, and the Colonial Intellectual in Bengal 1848-1885 (India: Oxford University Press, 2005); Joya Chatterjee, Bengal divided, Hindu communalism and Partition, 19321947 (New Delhi: Cambridge University Press, 1995).
} 
pay revenue to the original Muslim landlords. This resulted in Muslims losing their real position in society. As Muslim elites lost their power and position, they failed to support education for Muslim masses. Rahman demonstrated that the colonial government followed a laissez faire policy with regard to education, which led to the decline of the Muslims. Muslims did not have any commercial motive to study English, whereas Hindus were eager to learn English in order to secure jobs. Finally, missionaries and Sanskrit pundits working for the government ran the Fort William College and considered modern Bengali as the vernacular language of the province. This had an adverse effect on Muslim education as Arabic and Persian were excluded from the curriculum. He showed that apathy of Muslims was not the sole reason for their "backwardness." The lack of financial assistance to madrasshs (schools, which provided education in Islamic law, Koran, Arabic, and Persian) and maktabs (primary schools for Muslims), discontinuance of Arabic and Persian, and an adoption of a new curriculum forced Muslims to drop out of schools. ${ }^{4}$

Following Rahman, Dhurjati Prasad De argued that from the 1870s the government made special efforts to improve the educational situation of Muslims. By the late nineteenth century Muslims also realized that it was important to study English in order to progress under colonial rule. He demonstrated that the emerging Muslim middle class found it difficult to establish an exclusive Islamic culture, which was not dominated by Hindus. However, by the 1940s the Muslim middle class was able to develop a separate identity which synthesized both ashraf (upper class Muslims) and Bengali cultural traditions. ${ }^{5}$

The only publications that come close to my study are Poromesh Acharya's article "Education and Communal Politics in Bengal" and Mohammad Shah's book In Search of an

\footnotetext{
${ }^{4}$ Fazlur Rahman, The Bengali Muslims and English Education 1765-1835 (Dhaka: Bengali Academy, 1973); Sufia Ahmed, Muslim Community in Bengal 1884 -1912 (Dacca: Oxford University Press, 1974).

${ }^{5}$ Dhurjati Prasad De, Bengal Muslims in Search of Social Identity 1905-47 (Dhaka: The University Press Limited, 1998).
} 
Identity: Bengal Muslims 1880-1940. Acharya very briefly identified the three major problems with colonial education: Hindus dominated colonial education, problems over religious education, and language issues. Acharya demonstrated that communal politics in Bengal had been studied from the standpoint of land relations but not in terms of education. His article in a very limited way demonstrates how the introduction of the Bengal Secondary Education Bill of 1940 generated communal tension during the last phases of colonial rule. Shah argues that grievances in various fields like education, jobs, and representation in provincial assemblies strengthened separate political identities and communal feelings. Majority of the Muslims did not progress beyond the lowest levels and at every stage more Muslims dropped out in comparison to Hindus. Shah argues that separate educational institutions helped in maintaining traditional education and the ideals of Islamic culture. He showed that Muslims failed to make use of the limited opportunities provided by the colonial state and eventually followed a conservative religious policy. Religious conservatism increased communal solidarity. Shah discussed education in the context of identity and raised certain important points such as the establishment of the Dhaka University but his argument is mostly focused on the problem of separate political and communal identities rather than education. ${ }^{6}$

Ahmed, Vishwanathan, Bandopadhyay, and Shah have all made important contributions to the study of colonial education in India. However, Rahman restricted his work to the early nineteenth century and De focused only on the question of separate identity using colonial educational reforms superficially. Recent works on education by Bhattacharya and Sengupta have dealt with the problems of Muslim education, but in very limited ways. Departing

\footnotetext{
${ }^{6}$ Mohammad Shah, In Search of an Identity: Bengali Muslims 1880-1940 (Calcutta: K.P.Bagchi \&Co, 1996); Poromesh Archarya, "Education and Communal Politics in Bengal," Economic and Political Weekly 24 (1989), 8190.
} 
from the conventional paradigm, my research demonstrates the complexities of colonial education policies that initially deterred Muslims from acquiring Western education but later on motivated them to adopt it as a means to improve their position in the society. Second, my findings illustrate the complicated problems associated with the spread of education in Muslim districts including the debates within the Muslim community, absence of educational institutions in rural areas, and the financial crisis that affected the social position of Muslims. My work shows how elite Muslims deprived their rural co-religionists of the benefits of education, which brings to light the struggle within the Muslim community over education policies. Lastly, the dissertation provides a threefold analysis of how colonial education became the site of constant conflict between the colonial state and the Indian elites. Both Hindu and Muslim elites were involved in constant communal conflicts over colonial education policies, which strengthened the demand for separate schools and eventually a separate nation.

\section{Methodology and Analysis of the Sources}

The methodological uniqueness of my study lies in its use of the history of education to focus specifically on educational and communal problems. In the India Office Records Collection at the British Library, I examined the different reports of the Director of the Public Instruction for Bengal such as J.P.Grant and H. Sharp, and also important papers of Charles Wood (President of the Board of Control of East India Company) and Philip Hartog (the first Vice-Chancellor of the Dhaka University). These opinions are available in the form of private papers including the Hartog Collection and are also published in various English and vernacular (Bengali) newspapers including the Mussalman and Bangiya Muslim Sikha (Bengal Muslim Education). These private papers reflected the various methods used by colonial officers in India to implement the education policies formulated in London. Along with these reports and private 
papers, I examined various acts such as the Wood's Despatch of 1854, the Indian Education Commission of 1882, the University Act of 1904, the Bengal Rural Primary Education Bill of 1930, and the Bengal Secondary Education Bill of 1940, which were formulated by the colonial state and the Indian ministers. The examination of these acts has helped to formulate a broad and general perspective of the nature of colonial education policies. These resources have allowed me to examine the various points of collaboration and conflict between the colonial state and Muslim middle classes over education policies.

My research from these reports and private papers has revealed that colonial education policies changed over time from the nineteenth century to the twentieth century. By the early twentieth century privatization of education reached a new height. Lord Curzon increased the tuition fees as a method to improve the educational system of the province. After the Partition of Bengal in 1905, the effort to spread mass education was abandoned. Primary education was suffering, teachers did not receive proper salaries, the system of examinations was abolished, and textbooks were published in different dialects of Bengali. This had an adverse influence on the spread of education, as most families, especially poor Muslims, could not afford this Western model of private education. Curzon popularized the concept of the private residential system of education as a method to discipline students. According to Philip Hartog, a residential university improved the quality of education provided to natives.

Along with privatization, there was introduction of separate schools for Muslims and madrassahs were converted to secular institutions. The introduction of separate schools did not receive support from the entire Muslim community. For example, Abdul Karim, the school inspector, considered it to be a financial burden on the state. He demanded the establishment of more government schools and colleges for Muslims. At the same time, as the demand for 
separate schools increased throughout the 1920s, Muslims preferred to send their children to the Islamia College, established in 1926, instead of Presidency College where they could pursue both English and Arabic. I have also used opinions of Muslim students published in the Dhaka University Journal to evaluate whether separate institutions for Muslims improved the educational standards of the community. My dissertation shows that there are various aspects to the debate on education. The Western model of education was unsuitable for India as it was expensive for most Indians. The middle class that endorsed Western education now expressed their grievances over lack of government jobs, absence of financial assistance from the government, and dearth of colleges for Muslims in rural areas. The colonial education policies was not just controversial but was also one of the crucial factors that strengthened separate religious identities.

Along with the collections at the British Library, I completed extensive research at the West Bengal State Archive in Kolkata, the National Library in Kolkata, and the National Archive New Delhi over the summer and winter breaks of 2009, 2010, 2011, and 2012. The West Bengal State Archive has all the major documents on education such as the Proceedings of the Government of Bengal, the reports of the different committees formed by the Education Department for the improvement of education, and the private letters of important Muslim intellectuals like Abdul Karim. These documents helped to analyze the consequences of the major educational reforms introduced for Muslims between 1854 and 1947. The National Library in Kolkata has most of the Bengal Legislative Assembly Council Proceedings from 1900 to 1947 . These proceedings highlight the educational debates of the time. The debates answer important questions as to what kind of educational policies were preferred by both Hindus and Muslims during the late colonial period, how much money allocated for education by the 
colonial government, and so forth. These debates illustrate the conflict between Hindu and Muslim legislative assembly members over the extension of acts such as the Bengal Rural Primary Education Bill of 1930 and the Bengal Secondary Education Bill of 1940.

The National Archive in New Delhi has the census and native newspaper reports from the colonial period. The newspaper reports discussed how the colonial education policy was both supported and opposed by the middle classes in Kolkata and Dhaka. I have also examined important vernacular (Bengali) newspapers and English journals such as the Nabajug, Danik Bangla, Dhaka Prokash, Mussalman and the Moslem Chronicle. These documents helped to compare and contrast the education policies of Fazlul Huq, the education minister of Bengal, and Abdul Latif, the Professor of English at the Calcutta Madrassah, and analyze the social history behind educational and communal problems. A wide variety of archival sources have allowed me to combine the broad analysis with specific case studies. This shows how education policies became a highly contested site, influenced not just by the colonial state and the Indian society but also by the changing social circumstances of the colony. This methodology will refine our understanding of how education policies solidified communal feelings, which led to bitter tension between Hindus and Muslims during the end of colonial rule.

\section{Organization of the Chapters}

The study of colonial education policies in Bengal is divided into six chronological

periods, starting with the history of pre-colonial and colonial Bengal. The first chapter provides a brief history of pre-colonial and colonial Bengal to explain the social status of Muslims before the coming of the British and how it changed after the Mughals were defeated by the British in 1757. This chapter also analyzes some of the policies introduced by the colonial state such as the Permanent Settlement of 1793 that had a negative influence on the position of Muslims in 
colonial Bengal. It serves as a background to show how the existence of a composite culture changed under British rule.

The second chapter starts with the Charles Wood's Despatch of1854. The Wood's Despatch was the legislative act that introduced the system of grants-in-aid for the spread of mass education. The system of grants-in-aid was based on the concept of public-private partnership in education, which became crucial for the spread of primary and higher education in India. However, this model significantly increased private initiative in education. Wealthy individuals and private organizations such as the Tippera Muhammadan Educational Society established educational institutions, which to some extent received financial aid from the government. But these private agencies did not improve either the state or the standard of education. The second chapter of the dissertation shows that after the Wood's Despatch of 1854, the government in general decreased financial assistance to educational institutions and this affected the progress of Muslim education. Anglo-vernacular schools increased fees, which were beyond the capacity of poor Muslims. Moreover, elite institutions such as the Presidency College did not include Muslims. Government policies, poverty, and discrimination by Hindus prevented the advancement of the Muslim community in the nineteenth century.

The third period deals with the partial transformation in Muslim education from the Education Commission of 1882 to the Partition of Bengal in 1905. By the 1870s, the emerging Muslim intelligentsia realized the importance of English education. They wanted the government to provide additional scholarships and subsidize fees for Muslim students. Abdul Latif played a crucial role in changing the Muslim approach towards Western education. His effort was recognized by the colonial government and he was given the title of "Nawab" (King). However, these reforms were not sufficient to satisfy the needs of the total Muslim population of the 
province. The third chapter shows that by the late nineteenth century Muslims were eager to learn English as they wanted to improve their social position. It also highlights the role played by Latif in improving Muslim education. But, the education system continued to be based on the concept of public-private partnership with schools privately operated and Muslims in most cases could not afford these private schools. In response to these circumstances, elite Muslims demanded separate educational institutions as it helped Muslims to pursue both religious and English education. They also thought that in separate schools Muslims did not require to compete with Hindus. The colonial government accepted this proposal to gain the loyalty of the Muslims. The proposal to establish separate schools for Muslims further complicated the history of Muslim education in colonial Bengal.

The fourth chapter starts with the Partition of Bengal in 1905 and evaluates how education policies changed from the nineteenth to the twentieth century. After the Partition, the government further reduced financial assistance to educational institutions and private funds supported nearly 50 percent of the educational expenditure of Bengal. This chapter shows how the swadeshi (national) movement failed to integrate social and national discontent, which alienated Muslims and persuaded them to support the idea of separate educational institutions. This alienation led Muslims to support the establishment of the Dhaka University in 1921, which was predominantly a university for Muslims in Eastern Bengal.

The fifth chapter examines the impact of legislative acts such as the MontaguChelmsford reforms and the national movement on colonial education policies in the 1920s and 1930s. The separate Muslim educational institutions suffered from financial crisis and there were not enough scholarships for Muslim students. For example, the Dhaka University suffered from financial crisis immediately after its establishment as the government did not allocate enough 
funds for the improvement of the university. The curriculum of these separate institutions also did not suit the needs of the community. The separate schools mostly emphasized the study of Arabic and Persian, which did not help Muslim students to secure government jobs. Throughout the 1920s and 1930s, the absence of financial assistance from the government, a dearth of colleges for Muslims in rural areas, and the political crisis of the period aggravated the communal situation of the province. Hence, conceptually flawed policies strengthened the feeling of separateness in the Indian society, which eventually led to the birth of India and Pakistan in 1947.

The final chapter examines the state of Muslim education during the last decade of colonial rule. In particular it focuses on the role played by Fazlul Huq, the first Muslim Education Minister of Bengal, who campaigned for 50 percent reservation for Muslims in schools, colleges, and jobs. He made sincere efforts to increase government grants for Muslim education. But, the Secondary Education Bill of 1940, introduced by Huq, further complicated the relationship between Hindus and Muslims as it nominated members from separate Hindu and Muslim electorates for the secondary education board. Hindus opposed the bill because they feared it would lead to communal tension, while Muslims supported it because they anticipated that it would improve the status of the community. The intense debate over this bill made it clear that education for Muslims could only prosper in a separate nation. Finally, I argue that the absence of proper educational infrastructure along with financial and political crises forced Muslims to realize that their educational aspirations could only be fulfilled in a separate territory. In other words, separate educational institutions further increased Muslim separateness, which prepared the ground for the emergence of separate nations. 
My dissertation ends by providing a glimpse into the legacies of colonial education policies in India. Even after independence, private agencies controlled primary, secondary, and higher education in India, which created the same stratification as had existed during the colonial period. The dissertation will show not just the impact of colonial policies on Muslim education but also illustrate how inequalities on the basis of caste and religion existed in education even after independence. 
Chapter 1

\section{A brief History of Pre-Colonial and Colonial Bengal up to 1857}

\section{Mughal Bengal}

By the mid-seventeenth century, Mughals had established themselves throughout the Bengal delta. The advent of Mughal rule was not just a military occupation but was accompanied by fundamental changes in economic structure, socio-political system, and the cultural complex, both at court and the countryside. To begin with, Mughal power was concentrated at Dhaka, situated in the eastern part of Bengal. East Bengal was agriculturally more fertile and populated than West Bengal. East Bengal had two major seaports: Chittagong and Satgaon from where rice was exported to Southeast Asia. Along with rice, the cultivation of silk and cotton flourished throughout the Bengal delta. Richard Eaton argues that Bengal's manufacturing and agricultural boom coincided with the consolidation of Mughal rule. ${ }^{7}$

As the provincial capital, Dhaka was reserved for secular concerns such as revenue collection, politics, and military issues. Hindus were based in the western part of Bengal. A large number of temples were built in West Bengal during Mughal rule that were dedicated to Hindu Gods, Vishnu and Shiva. Mughals in Bengal did not promote forceful conversion of the Bengalis to Islam. The Mughal officers from North India used their religious beliefs to maintain a distance from the indigenous people of Bengal. Islam Khan discouraged the conversion of Bengali Hindus and on one occasion he punished one of his officers for converting Bengali Hindus. In

\footnotetext{
${ }^{7}$ Richard Eaton, The Rise of Islam and the Bengal Frontier, 1204 -1760 (Berkeley: University of California Press, 1993), 150-8. Dhaka: The Mughals selected Dhaka because it was the most fertile part of the Bengal delta but was still not developed. As opposed to the Western part, where the existing zamindars had a strong base, Mughals created an agrarian base in the east, which was covered with marsh and forest.
} 
practice, Mughals followed a policy of non-intervention. Eaton showed that Mughals conquered Bengal because they were interested in the wealth of the region and not their religion. ${ }^{8}$

Akbar's conquest of the delta in 1574 integrated the delta with North India. Prior to the coming of the Mughals, the hinterland was undeveloped but the expansion of Mughal rule led to the establishment of new agrarian communities. Immigrants from West Bengal, North India, and the indigenous peasants of East Bengal helped to develop the hinterland. Under Mughal rule, high caste Brahmins in Bengal established themselves as zamindars (landlords). However, Islam in Bengal was successful because of pirs and the system of land tenure. The authority of the pirs was connected with forests, mosques, and the ability to dominate the supernatural world. But their connection with mosques helped in establishing the cult of Islam. Over time, the pirs were landholders, which gave birth to a new class of men in pre-colonial Bengal known as the “religious gentry.”(Eaton, 219) Piety and the system of land tenure helped in establishing Islam in the countryside. Islam in pre-colonial Bengal had the capacity to adapt to the land and the culture of the people, while transforming both. As a result, the cultivators were Muslims who made every effort to bring the waste lands of East Bengal under cultivation. ${ }^{9}$

Islam in pre-colonial Bengal was considered a "civilization building ideology." (Eaton, 308) The religious authority was possessed by hundreds of mosques and shrines that were established along the delta. Islam had identified with the local culture and was associated with Bengal's agrarian expansion. For example, Muslim cultivators in the twentieth century still retained their indigenous names such 'Chand,' 'Pal,' and 'Dutt.' Eaton shows that Islam in

\footnotetext{
${ }^{8}$ Ibid.,178-9. Islam Khan, the Mughal officer who conquered Bengal, and was able to win over the major chiefs that were located in the countryside. He defeated and killed Uthman Khan thereby overpowered Afghan resistance in the delta. He passed away in 1613 .

${ }^{9}$ Pir, a Persian word, which means "spiritual director or guide among Muslim mystics referred to as sufis. Asim Roy, The Islamic Syncretistic Tradition in Bengal (Princeton: Princeton University Press, 1983), 50-1. See Eaton, The Rise of Islam and the Bengal Frontier, 1204 -1760, 218-9.
} 
Bengal was involved with agrarian expansion, eastward migration and settlement of the colonizers from the West and the North, incorporation of tribal people into the mainstream, and the production of surplus food grains. Mughal Bengal was characterized by physical expansion and religious integration. ${ }^{10}$

In terms of education, Vedic learning was the dominant form of education in Bengal even during Mughal rule. However, Brahmanic control diminished as one moved from West to East Bengal. The absence of a dominant religion in East Bengal helped Islam and Koran schools to have a greater power over the population. Mosque builders and rural mullas (Islamic clerics) gained control over the region through their charismatic nature and emphasis on Allah. The study of Koran became important and Arabic was considered the most important language for the Muslims. For example, Arabic was so important that even Bengali Muslims were reluctant to translate the Koran or Islamic popular lore into Bengali. Moreover, the papermaking technology allowed scriptures to be published, which helped in the spread of literacy far beyond the urban centers. ${ }^{11}$

In the field of pre-colonial education, Fazlur Rahman argues that before the advent of British rule, education in India was based on Islamic theology. To a Muslim, education was always religious. Large estates were provided by the state for the establishment of madrassahs and maktabs. Maktabs and madrassahs included both Hindus and Muslims, which broke the monopoly of the Brahmins. Religious education was considered an act of piety and the madrassahs were either financed by a single person or through trusts and grants. Students got free education and they were not required to buy any textbooks. For the teacher, teaching was the

\footnotetext{
${ }^{10}$ Ibid., 308-10.

${ }^{11}$ Ibid., 291-3.
} 
profession where he could do productive work for religious benefits. Moreover, there were two kinds of schools: Arabic and Persian. Arabic schools had complete courses on reading, rhetoric, logic, and law. The elementary Arabic schools only provided education in the Koran. The Persian schools were far more organized than the Arabic schools and they used Persian manuscripts to advance learning. Education at Persian schools helped students to secure government jobs. ${ }^{12}$

. As opposed to the British view that India was a despotic country, Eaton argues that in pre-colonial Bengal, Islam acted as an integrating religion. Mosque schools, which were more in number in the eastern part of Bengal, helped to spread literacy. The curriculum revolved around the study of Islam and Arabic. Persian education was used to secure government jobs. According to Eaton, a vibrant education system existed under Mughal rule, which was supported by the Mughal state. Eaton also shows that along with the ruling class, peasant cultivators adopted Islam as a way of life. Islam was a religion of the plough. Under Mughal rule, Islam came to be identified with both economic development and agricultural productivity. Following Eaton, Ishrat Haque opposes the view that during the last days of Mughal rule a gloomy political situation existed in India. Mughal social organizations and political institutions continued even in the early British period. Haque argues that British intervention destroyed the political setup of the Mughal period and changed the balance that existed among various regional, local, and ethnic elements. Similarly, Samar Deen in his unpublished paper shows the existence of religious pluralism and cultural syncretism in the eighteenth century before the coming of the British. Deen uses several Urdu poems such as Hunsnama and Banjara to show the role played by religion in influencing the character and culture of the people of the sub-continent. Diverse

\footnotetext{
${ }^{12}$ See Rahman, The Bengali Muslims and English Education 1765-1835, 2-8.
} 
religious sects existed in India before the coming of the British and it helped the Indian

community to live together. ${ }^{13}$

Towards the end of Mughal rule, the British and the French were major competitors in both European and Asian trade. They were fighting with each other in south and east India. The principle settlement of Calcutta was won by the British army under the leadership of Robert Clive in 1757. In reality, the actual beginning of the British rule in Bengal started with the imperial grant of the diwani in 1765. However, after the British conquest of Bengal we notice both a shift from, and continuation of, Mughal policies under the new colonial order. The British had to devise a vision to sustain their rule and shape India's future. ${ }^{14}$

\section{Colonial Bengal}

The conquest was followed by an extended period of residency in India. P. J. Marshall argues that East India Company's early regime was extremely ambitious and powerful. It wanted to have a complete control over the territory it conquered. By 1765 Bengal became a British dominion and Calcutta was the most important city. The British did not change the structure of the state created by the Mughals and they needed the help of the Mughal nobility to run the state.

\footnotetext{
${ }^{13}$ Ishrat Haque, Glimpses of Mughal Society and Culture: A Study Based on Urdu Literature in the $2^{\text {nd }}$ Half of the $18^{\text {th }}$ Century (New Delhi: Concept Publishing Company, 1992),13-28. See Eaton, The Rise of Islam and the Bengal Frontier, 1204 -1760, 305; Samar Deen, "Pluralism in $18^{\text {th }}$ century India. Exploring Human Ecological Relations in Urdu Folklore through Nazir Akbarabadi's poems (1740-1830)" (Unpublished research paper, Academia, Cornell University, New York, accessed May 17, 2016, https://www.academia.edu/8743952/Pluralism_in_18th_century_India_Nazir_Akbar_Abadi)

14 Thomas Metcalfe, Ideologies of the Raj (Cambridge: Cambridge University Press, 1995), 8; P.J. Marshall, "Introduction," in The Eighteenth Century in Indian History: Evolution or Revolution? ed. P.J. Marshall (New Delhi: Oxford University Press, 2003), 19-20. Robert Clive: Major General Robert Clive was the Commander -inChief of the British army that established the rule of the East India Company over Bengal in 1757. Clive defeated Siraj-ud-Dallauh's army of 50,000 soldiers with the help of Mir Jafar. Clive led Mir Jafar to the throne of Murshidabad after killing Siraj-ud-dallauh. Diwani: The East India Company collected the revenue as the diwan . This allowed the British to plunder the region. Clive himself accepted that "such a scene of anarchy, confusion, bribery, corruption, and extortion was never seen or heard in any country but Bengal; nor such and so many fortunes acquired in so unjust and rapacious manner." Stanley Wolpert, A New History of India (New Delhi: Oxford University Press, 2009), 192.
} 
Muslim law officers and Hindu pundits were not just subservient to their new masters but they expressed their opinions about the British system of administration. The British were still dependent on zamindars and other intermediaries for revenue collection. The services of the Indian commercial men were also important to the British. The bankers of Benares handled the finances of the Company after the battle of the Plassey. In the late eighteenth century, the nawabs, intermediaries, and Indian bankers played an important role in maintaining the colonial state. $^{15}$

Marshall shows that the Company "wanted to create prosperity through secure rights and free trade." (Marshall, 32) Yet, they wanted to keep Bengal's silk and cotton cultivation under their control. As a result, the trading activities of the Indian merchants were restricted. The Company either established monopolies over the trade or brought weavers and spinners, who were mostly Muslims under their control. The Indian commercial communities benefited from colonial rule. But Hindu and Muslim peasants were impoverished. This was mainly because of the drive for higher revenue or control over the labor force. Suchetana Chattopadhyay argues that the Hindu bhadraloks, who were products of the colonial rule, played an important role in depriving both the Hindu and Muslim peasantry of education. The Hindu bhadraloks worked either as professionals or landed proprietors. It was this class of people who were able to send their children to the elite schools of Calcutta. Similar attitudes were shared by elite Muslims towards the end of the nineteenth century. As a result of this deprivation, only elite Muslims were able to avail the benefits of Western education. ${ }^{16}$

\footnotetext{
${ }^{15}$ See Marshall, "Introduction," in The Eighteenth Century in Indian History: Evolution or Revolution? ed. P.J. Marshall, 31-2.

${ }^{16}$ Ibid., 31-5. Suchetana Chattopadhyay, "Muzaffar Ahmad, Calcutta, and Socialist Politics, 1913-1929" (PhD diss., University of London, 2004), 18-21. Suchetana Chattopadhyay in her dissertation uses the example of the island of Sandip to show how lower caste-class Hindus and Muslims were deprived of education by high caste zamindars.
} 
Although the East India Company established their monopolies over trade, yet they were concerned as to how far and in what ways they should govern India. They embarked upon a more detailed study of India and had to devise principles that helped them to justify their rule. Philip Francis, a member of the Supreme Council in Bengal, introduced the first comprehensive plan for the rule of property in 1776 . He believed that the landlord was the sole proprietor of the land and his rights had to be protected. This idea was used by Lord Cornwallis, the GovernorGeneral of India, when he introduced Permanent Settlement in 1793. Cornwallis thought that Permanent Settlement would bring about an agrarian revolution in Bengal. Before the introduction of Permanent Settlement, the Muslim landlords had delegated to the Hindu rentier class the duty of collecting taxes. The rentier class took advantage of the situation and extracted huge revenue from the Muslim peasants. This affected the position of both the Muslim peasants and zamindars. Muslim peasants and zamindars lost control over the land. Tenants had no protection and were left at the mercy of the Hindu rentier class. The rentier class emerged as the absentee landlords and was referred to as abhijato bhadraloks or aristocrats. The self-styled aristocrats were supporters of free trade and natural allies of the East India Company. Madhumita Roy argues that the beneficiaries of the British colonial rule were not a unitary group. The abhijato bhadraloks were divided on the basis of loyalties to their castes and subcastes, proximity to specific British groups (the Company or free traders), and sources of income (absentee landlordism or commerce). Despite being a fractured group, they demanded liberalization of British rule rather than abolition. ${ }^{17}$

This deprivation motivated the peasantry to create zones of social interactions, which did not include their community identities.

${ }^{17}$ See Metcalfe, Ideologies of the Raj, 1-20; Madhumita Roy, "Englishing India, Reinstituting Class and Social Privilege," Social Text (Summer 1994), 94-6. 
A section of bhadraloks readily adopted Western education as it helped them to advance under colonial rule. However, not all bhadraloks readily accepted Western education. But the enthusiasm for English education was far greater than the resistance to it. As a result, the emerging bhadraloks established the Hindu College in Calcutta in 1817, which provided instruction in English and the literature of Europe. The elites were also part of the Calcutta School Book Society and the Calcutta School Society, both of which played an important role in the dissemination of primary education. The curriculum in the primary schools included English language and literature, English history, geography, and mathematics. The Company conducted its business by collaborating with these self-styled aristocrats. Along with the aristocrats, the middle class or the professional petit-bourgeoisie, drawn from different social groups, also collaborated with the British. They served as junior administrators and clerks. According to Roy, "they were auxiliaries of the empire."18 (Roy, 96)

Roy argues that English was the language of the rulers and the acquisition of English helped the middle class to acquire social mobility and material prosperity. The knowledge of English was necessary for the purpose of jobs. Over time, the knowledge of English helped the middle class to dominate government jobs. Indigenous elites clearly aided the introduction of English as the official language. For the British, Englishing India meant better consumers of British products and a more efficient way of meeting the demands of a vast administration. For the Indians, it gave them better jobs. Finally, Roy concludes by indicating that a miniscule portion of the Indian population lived lavishly under British rule. For example, the banians or business agents of did very well under colonial rule. The people who made their income from

\footnotetext{
${ }^{18}$ Ibid, 96; See Chatterjee, Bengal divided, Hindu communalism and Partition, 1932-1947, 8-9.
} 
land revenue or trade also had opportunities to prosper. But the general condition of the masses was harsh and deplorable. ${ }^{19}$

The introduction of English education deepened the social division based on caste and class. Upper caste Hindus living in urban areas only made use of the opportunities provided by the colonial state. This group remained loyal to the colonial state. Hindus were fortunate both in the field of land settlement and in commercial relations. By collaborating with the British, the Hindus tried to ameliorate their condition. Muslim elites would also try to improve their situation towards the end of the nineteenth century. But the poor Muslim farmers and peasants living in the countryside had no access to the educational institutions that were located in cities. Even the schools that started in East Bengal were located in the urban centers from where they were forced to evacuate due to economic reasons. Muslims failed to progress during the first half of the nineteenth century because of geography, initial difference in economic welfare, and the colonial government's unwillingness to provide to education to the Muslims. ${ }^{20}$

Along with education, Lord Dalhousie, the Governor-General of India from 1848 to 1856, wanted to further Westernize India and his reign was referred to as the "second age of reform.”(Metcalfe, 42) Metcalfe argues that mid-Victorian liberalism united Whigs, liberals, and radicals within the limits of the liberal program. Dalhousie wanted to Westernize India and tried his best to abolish the practice of female infanticide, sati (widow burning) in princely states, and human sacrifice. He also helped the Christian converts secure their ancestral property. As these reforms were getting introduced, missionary activities also strengthened their control over India.

\footnotetext{
${ }^{19}$ Ibid, 96-102; See Marshall, "Introduction," in The Eighteenth Century in Indian History: Evolution or Revolution? ed. P.J. Marshall, 34.

${ }^{20}$ Aminur Rahman, "The Political Economy of English education in Muslim Bengal: 1871-1912," Comparative Education Review, 36 (August 1992), 311-3; Fazlur Rahman, The Bengali Muslims and English Education 17651835 (Dhaka: Bengali Academy, 1973), 24-6.
} 
The strongest was in the army, where the officers wanted to convert their regiments. The government did not support the evangelical endeavors and rather tried to follow the secular path. However, Metcalfe argues that under Bentinck and Dalhousie, the colonial government was considered an agent of aggressive social change. They wanted to modernize the Hindu religion by introducing Western education. Similarly, a section of the Western educated intelligentsia conformed to the prescribed codes and supported the liberal remaking of India. ${ }^{21}$

Liberal values shaped the British transformation of India throughout the first part of the 1850s. The introduction of Western education and the campaign against sati reinforced the idea that the British were reforming the uncivilized Indian society. But the liberal remaking of India disappeared after the Revolt of 1857 , which forced the British to think about alternate visions of the empire. At the same time, there was a rise of Hindu revivalism, which was based on the loss of self-esteem and opposition to colonial rule. The anti-Muslim rhetoric was one of the most important aspects of the rising Hindu nationalism. For example, Bengali writers such as Bamkimchandra, openly fostered anti-Muslim sentiments. Others like Rajnarayan Basu campaigned for cooperation with Muslims against colonial rule. Tapan Raychaudhuri indicates that Bengalis were extremely selective in their appreciation of European civilization. Strong nationalist sentiments forced both Bengali Hindus and Muslims to critically evaluate British rule and the greatness of the European civilization. Against this backdrop, the next two chapters will examine in details the problems related to colonial education policies and their impact on the

\footnotetext{
${ }^{21}$ Thomas Metcalfe, Aftermath of the Revolt, India 1850-1870 (Princeton: Princeton University Press, 1964), 28-30. Lord William Bentinck: The Governor General of India from 1833 to 1835. He embarked upon social reforms and sought to free India from the bondage of priests, despots, and feudal aristocrats. Lord Dalhousie: The Governor General of India from 1848 to 1856 . He introduced the system of "Doctrine of Lapse" where any princely state that did not produce a male heir was annexed by the British. His policy of annexation further consolidated British rule in India. Tapan Raychaudhuri, Europe Reconsidered: Perceptions of the West in Nineteenth century Bengal (New Delhi: Oxford University Press, 1988), 2-3.
} 
Muslims during the first half of the nineteenth century and the changing Muslim approach towards the British after 1857, especially, in terms of education. ${ }^{22}$

\footnotetext{
${ }^{22}$ See Metcalfe, Ideologies of the Raj, 41-3; See Raychaudhuri, Europe Reconsidered: Perceptions of the West in Nineteenth century Bengal, 10-15.
} 
Chapter 2

\section{Public Debates on the Wood's Despatch and the spread of English education in Nineteenth Century Bengal}

\section{Introduction}

The effort to introduce English language education and also instruction through the medium of English in India remained a contentious problem for the British colonial government until the Charles Wood's Despatch of 1854. For the British, education was not only an expression of cultural dominance but also a means to create loyal subjects. Conversely, Indians used education to achieve class and social mobility. The introduction of English as the administrative language triggered a long and protracted debate initiated by the ideological conflict between the so-called Orientalists and Anglicists. The Orientalists, such as William Jones, wanted to synthesize new Western values with the old cultural fabric of India. ${ }^{23}$ They believed that Indians should use Western values to modernize their own thoughts and develop along their own lines. The Anglicists, such as Lord William Bentinck, believed in the diffusion of English over the vernacular languages of India. Languages such as Sanskrit and Arabic were not sufficiently developed to provide education in European subjects. According to the Anglicists, the Orientalist form of education did not improve the standard of education in India. English had to replace Persian on the grounds that the latter was a dead language for both Europeans and Indians. Gradually, the Orientalists lost ground and surrendered to the superiority of English over Sanskrit. In practice, the spread of English education provided an immediate solution to the problem of supplying an adequate number of competent Indian clerks and civil

\footnotetext{
${ }^{23}$ See Metcalfe, Ideologies of the Raj, 10-1.William Jones: First President of the Asiatic Society founded in 1784 under the patronage of Warren Hastings. Asiatic Society undertook translations of Persian and Sanskrit texts and published its scholarly endeavors in Asiatik Researches.
} 
servants. It also brought about a change in the British attitude towards India; they considered themselves as guardians of the nation. The idea of public welfare was part of their project. ${ }^{24}$ Another important landmark in the history of Indian education was the Charles Wood's Despatch of 1854. The Wood's Despatch was also known as the Educational Despatch of 1854. The despatch proposed to improve the existing schools and colleges and also established the first universities in India. The first chapter of this dissertation briefly discusses the criticisms encountered by the despatch and assesses whether it was a success or a failure. The Calcutta University, established in 1854 , is used here as a case study to examine how far the spread of English education obstructed the development of vernacular education. Finally, this chapter also demonstrates how the Wood's Despatch of 1854 advanced the differences between Hindus and Muslims.

The government effort to spread secular Western education in colonial Bengal conflicted with the religious beliefs of the Muslims. Religious instruction formed an integral of being a liberal Muslim. However, the colonial government maintained a policy of strict religious neutrality as a result of which maktabs and madrassahs did not receive any government support. Muslims could not adjust with the changes introduced by the colonial state. They fell behind the Hindus in terms of education and employment, which required the knowledge of English. Along with the absence of religious education, structural problems associated with the despatch further complicated the educational problems of the province. Despite the emphasis to spread vernacular education, the system of grants-in-aid introduced by the colonial state further popularized English education as grants were only given to well established schools, which mostly taught English. To the British, the knowledge of English modernized the Indian society. The failure to adjust to the more private and secular system of education marginalized Muslims in the colonial

\footnotetext{
${ }^{24}$ See Acharya, The Changing Pattern of Education in Early Nineteenth Century Bengal, 1-26.
} 
society. This marginalization also increased the inequality in the society as Muslims lost their jobs and were reduced to poverty. The inequality in education aggravated the tension between Hindus and Muslims in the nineteenth century, which became further complicated in the twentieth century.

\section{East India Company and Education (1757-1854)}

After the conquest of India in 1757, the major problem for the East India Company was how to govern such a vast country. From 1780s onwards, the East India Company was transformed into a governing body and its servants were no longer traders but magistrates and judges. Great Britain considered itself preeminently civilized and modern and India was considered a despotic country because of centuries of Mughal rule. The British wanted to restore what they thought had been a golden age under Hindu rulers. Hence, they decided to introduce "the ancient institutions of the country" (Metcalfe, 21) by awarding property rights to the zamindars. However, Whig reforms such as the Permanent Settlement of 1793 did not produce effective results. The zamindars had to pay fixed revenue to the Company but the Company did not fix the taxes that the peasants had to pay to the zamindars. The Company gave the zamindars complete control over the land. The peasants lost their lands to the zamindars as they were unable to pay the high taxes. Shibaji Bandopadhyay argues that the Permanent Settlement changed the social fabric of Bengal. Problems between zamindars and ryots (peasants) existed even during the Mughal period but under colonialism, a very small section of the high caste Hindus controlled most of the lands and exploited both Hindu and Muslim peasants. ${ }^{25}$

This exploitation was not really condemned by Indian social reformers such as Iswar Chandra Vidyasagar or Raja Rammohan Roy. Vidyasagar in his work titled Banglar Itahas

\footnotetext{
${ }^{25}$ See Metcalfe, Ideologies of the Raj, 20-1; Bandopadhyay, Gopal Rakhal Dandosamas: Uponibeshbad o Bangla Sishu Sahitya, 26-9.
} 
(History of Bengal) indicated that Permanent Settlement overall improved the situation of Bengal. He was only worried about the fact that the colonial government did not have any rules for improving the situation of landless peasants. Similarly, Rammohan Roy accepted Permanent Settlement but thought that it had to be adjusted to the Indian situation. Roy wanted the British to continue their rule in India as that would benefit his countrymen. Bandopadhyay argues that Roy was not really familiar with the policy of free market trade under colonial rule. The emerging elites shared a complex rather paradoxical position in the colonial society. They both accepted and rejected colonial policies both in terms of education and land relations. ${ }^{26}$

To the British, India as a land lost in its past and shaped by the distinctive character of their religion and social institutions. The British thought they were upright and humane but the Indians were uniquely corrupt. This vision motivated Lord William Bentinck to embark upon social reforms influenced by the rising liberal ideas. The British hoped that India would become a laboratory for the creation of a liberal administrative state where state sponsored education, codified law, and competitive bureaucracy would flourish. The East India Company, in an attempt to understand the nature of the Indian society and religion, devised an ideology that helped to sustain their rule. These principles included the rule of law, security of private property, individual freedom, and Western knowledge. Liberal ideas of improving the Indian society guided colonial ideology throughout the nineteenth century. ${ }^{27}$

The idea of improvement started by Warren Hastings ${ }^{28}$ and William Jones led to the establishment of the Asiatic Society in 1784 for the study of Indian languages and laws. Along

\footnotetext{
${ }^{26}$ Ibid. 30-3.

${ }^{27}$ Ibid., $1-42$.

${ }^{28}$ Warren Hastings: He was the First Governor of Bengal and was influenced by enlightenment ideal of understanding all cultures. He believed that it was important to introduce language and science education in India.
} 
with the Asiatic Society, J. Duncan, a resident of Benares, suggested the establishment of a Hindu College or Academy in Benares (part of the Bengal presidency) for the study of laws, literature, and religion of the nation. Similarly, Hastings recommended the establishment of a madrassah in Calcutta for the study of Arabic and Persian law. He was convinced that an institution like the Calcutta Madrassah was important for instructing young students in Muslim law and sciences and assigned 51,000 rupees for the establishment of the Calcutta Madrassah. Both Hastings and Duncan strongly believed that these colleges would increase the faith of the Indians (Bengalis) in the colonial government. ${ }^{29}$

However, this improvement was closely associated with the fact that colonizers misunderstood the nature of the indigenous form of education. It was a system completely different from the one that existed in Great Britain and so they felt it necessary to improve the condition of indigenous learning. For example, Frederic Pincott's "Popular Education in Bengal" published in St. James Magazine in1862, indicated that in the first half of the nineteenth century Bengal had just three or four indigenous schools that were situated three or four miles apart. Village teachers provided elementary education. According to Pincott, the existing schools had to be remodeled, superior quality teachers had to be appointed, and scholarships had to be assigned to students. A greater effort on the part of the government was needed to improve the educational situation of the province. Similarly, James Hutton, in "The Education Question in Bengal" urged the government to improve the education system prevalent in Bengal. He believed that the "downward filtration theory" was the only method to educate the lower classes in Bengal and used the example of Baboo Joykissen Mookherjee to substantiate his argument. Joykissen

This form of education would increase the faith of the Indians in the colonial state. See Metcalfe, Ideologies of the Raj, 10.

29 J. Duncan, "Letter from J. Duncan to Earl of Cornwallis 1792," in Selections from Educational Records 1781 1839, ed. Henry Sharp (Calcutta: Superintendant Government Printing, 1920), 10-1. 
Mookherjee had a stable income of 10,000 pounds a year and donated 1,200 pounds annually for the maintenance of indigenous schools for the lower classes. According to Hutton, a joint effort was required by the state and the rich Indian landlords to improve the education of the masses. Holt Mackenzie also suggested that it was impossible for the colonial government to provide education to such a large body of people. He recommended that the colonial government should educate only a section of the society, usually the elites, who in turn would spread the knowledge provided by the colonizers. ${ }^{30}$

Following Pincott, Hutton, and Mackenzie, W. Frasier, a member of the Board of Revenue, requested government help for improving the condition of indigenous schools. He established four schools, which provided simple elementary education to peasants and wanted boys to learn English, Hindi and Persian languages. He noticed that parents did not send their children to school until they received some form of ration or incentive to support their children's education. In the British view, indigenous form of education was backward and this view helped the Orientalists to continue with their project in the late eighteenth century. Jones considered contemporary Indians to be relics of antiquity and believed that Asian learning proved advantageous for the British. Yet, he was strongly committed to the superiority of the English institutions and believed that the Indian system of education did not produce effective results. It was necessary to improve it based on the British model of education. ${ }^{31}$

\footnotetext{
${ }^{30}$ Fredric Pincott, "Popular Education in Bengal," St James Magazine, (November 1862), 483-79; Holt Mackenzie, "Note by Holt Mackenzie July 1823," in Selections from Educational Records 1781-1839, ed. Henry Sharp (Calcutta: Superintendant, Government Printing, 1920), 57-64; James Hutton, "The Educational Question in Bengal," St James Magazine, (October 1871), 604-18. Downward Filtration Theory: The colonial state would provide Western education through the medium of English to Indian elites who in turn would educate the masses at the bottom of the social ladder in English. Holt Mackenzie: He was the President of the Fort William College in Calcutta and strongly advocated for the Indianization of civil services that was blocked by Lord Cornwallis.

${ }^{31}$ W. Frasier, "Letter from W. Frasier to the Chief Secretary, Fort William 1823," in Selections from Educational Records 1781-1839, ed. Henry Sharp (Calcutta: Superintendant Government Printing, 1920).
} 
The effort to spread English education led to a controversy between the Orientalists, officers who supported the study of oriental languages, and the Anglicists, who supported English education. By the early nineteenth century, the Directors of the East India Company had begun to question the previous stress laid on the study of oriental languages and laws. Charles Grant, an Anglicist, suggested that Indians could be brought to light by introducing them to English education. The colonial government at a moderate expense could establish schools for providing instruction in English to Hindus, and over a period of time Hindus would become the teachers of English. He recommended the introduction and the use of English in administration instead of Persian. Following Grant, Macaulay in 1824 indicated that English had to be the medium of instruction for the Indians. He believed that Indians themselves were enthusiastic about studying English and strongly advocated that the study of English would benefit both the colonizer and the colonized. The British needed to study the ancient writings of Greeks and Romans to progress; similarly, Indians needed English education to understand Western science and literature. According to Macaulay, this was the only method for the Indians to progress. Scholars have argued that this was part of a design to create a class of bourgeois Indians, who in turn would support colonial rule. Over time, the conflict between the Orientalists and the Anglicists reached its height in 1835 with Thomas Babington Macaulay's "Minute on Education." 32

Finally, Lord William Bentinck in 1837 formally accepted English as the language of administration and instruction and declared that the government would not spend any more money on buying Sanskrit and Persian texts. However, Indian reformers such as Raja

\footnotetext{
${ }^{32}$ Charles Grant, "Grant's Observation on the state of society among the Asiatic subjects of Great Britain 1792," in Selections from Educational Records 1781-1839, ed. Henry Sharp (Calcutta: Superintendant Government Printing, 1920), 81-6; Thomas Babington Macaulay: An Anglicist, who favored English education over Oriental learning and believed that English education could reshape the image of India.
} 
Rammohan Roy supported the introduction of English education. According to Roy, the Sanskrit school, which was established in Calcutta in 1824, reflected the desire of the colonial government to improve education among Indians. But the school was managed by Hindu pundits who mostly provided instruction in Sanskrit grammar. He criticized the orthodoxy of the Hindu pundits, opposed conservatism and superstition, which were part of Sanskrit teaching. Roy suggested that the colonial government should adopt a liberal and an enlightened system of education. This will benefit Indians as they will become aware of European science and natural philosophy. ${ }^{33}$

Analyzing the complicated position of Roy and Vidyasagar, Himani Banerji argues that English was not merely a language of administration or communication. The knowledge of English helped the Bengali middle class to distinguish themselves from the non-middle class. For example, Iswar Chandra Vidyasagar walked a few hundred kilometers from Mednipur to Calcutta to learn English numbers. Adapted and translated European and English literature became very important to Bengali middle class. Shakespeare and Byron became household names. Akshay Kumar, a lawyer and a Bengali poet in nineteenth century Bengal, translated European and English novels to Bengali. Banerji argues that the essays and poems written by the Western educated Bengalis synthesized the two worlds. Western education and also translation of English novels to the vernacular helped the Bengali middle class to become familiar with English bourgeois attitudes. She further argues that such attitudes were also transmitted through vernacular textbooks of Iswar Chandra Vidyasagar. Through his textbook, Vidyasagar advocated that to become a gentleman formal English education was necessary. By analyzing the texts,

\footnotetext{
${ }^{33}$ Raja Rammohan Roy, “Address dated $11^{\text {th }}$ December 1823, from Raja Rammohan Roy," in Selections from Educational Records 1781-1839, ed. Henry Sharp (Calcutta: Superintendant Government Printing, 1920), 98-101; Raja Rammohan Roy: An English educated Indian, who played a crucial role in establishing the Hindu College. He wanted to synthesize Hindu, Islamic, and Western cultural traditions. Sumit Sarkar, A Critique of Colonial India (Calcutta: Papyrus, 1985), 2-4; See Roy, "Englishing India, Reinstituting Class and Social Privilege,” 99.
} 
Banerji shows that the content of education made the Bengalis aware of their class. Modern education, especially the knowledge of English, created a sense of class consciousness among the emerging Bengali middle class. This sense of class distinguished the middle class from peasants who lived in rural areas and did not have access to English. ${ }^{34}$

The introduction of Western education created a class of Hindus who acted as agents of the colonial government. They enjoyed added advantages such as entry into government services. However, the entire bhadralok class could not benefit from this system of education. For example, Madhusudan Dutta was a Bengali poet and an ardent Anglicist. His love for European literature led him to learn not just English but also French and Italian. He also converted and became a Christian. But during the time of indigo revolt he wrote Nil Darpan, where he supported the rebels. By using the example of Madhusudan Dutta, Bannerji argues that the Bengali middle class, which emerged during colonial rule, were influenced by the bourgeois world of the West. But they were still attached to their indigenous roots, which made them extremely critical of Western education and colonialism in general. Social reformers such as Vidyasagar, Rammohan Roy, and Keshab Chandra Sen were influenced by Western ideas and education but they were unable to transcend the contradictions of their class. This was similar even in the case of Muslims towards the end of the nineteenth century. ${ }^{35}$

Both primary and secondary sources indicate that with the introduction of Western education, the question of class became very significant. Western education modernized the outlook of the bhadraloks. They appreciated European literature and internalized bourgeois attitudes. But they found it very difficult to support colonial exploitation as in the case of

\footnotetext{
${ }^{34}$ Himani Banerji, "The Mirror of Class: Class Subjectivity and Politics in $19^{\text {th }}$ Century Bengal," Economic and Political Weekly, 24 (May 13, 1989), 1041-51.

${ }^{35}$ Ibid.
} 
Madhusudan Dutta. The bhadraloks were trapped in their own world and shared a very complex position in terms of modern education and society.

\section{Company Rule and Muslim education}

Before the British conquest of India, the Muslim concept of education was primarily religious. Educational institutions were established on large estates and the Mughal government provided generous grants to support education. However, the support was extended not just to Muslim but also Hindu schools. Fazlur Rahman has argued that this common state patronage led to the assimilation of Hindu and Muslim languages and literature and helped the non-Brahmins to break the monopoly of the Brahmins. Nobles and chiefs started madrassahs and maktabs. There were no reliable records of these schools except for William Adam's reports. However, when Adam compiled his reports, these institutions were in a state of progressive decay as the colonial government did not support these institutions. Persian was the medium of instruction and this was because of its close association with Islam. However, with the introduction of colonial rule, Muslims could not adjust with the new secular system of English education. Moreover, most of the mosque schools also functioned as community centers of the villages. In these schools, students were not required to pay any fees and they paid minimal fees when they went to more advanced schools. In contrast, students had to pay fees for their education under British rule. Over time, the mosque schools gradually declined with the decrease in wealthy individuals and landlords among Muslims in rural areas. ${ }^{36}$

\footnotetext{
${ }^{36}$ See Rahman, The Bengali Muslims and English Education 1765-1835, 4-11. William Adam: He was appointed by the British East India Company in 1835 to survey the condition of indigenous education in the districts of Birbhum, Burdwan, Murshidabad, and Rajshahi. In his first report in July 1835, Adam, showed that the province of Bengal had of total is 1,800 tols with 12,600 teachers and students. In his second report in December 1835, Adam paid tribute to the teachers of tols and pathsalas for their intellect. Adam conducted his survey till 1838. See Acharya, The Changing Pattern of Education In Early Nineteenth Century Bengal, 39-41.
} 
After the Battle of Plassey in 1757, Bengal plunged into misery and destitution. The East India Company started a deliberate policy of confiscating tax-free lands on which these educational institutions were built. As a result of this policy, the educational institutions lost their endowments and were ruined. After 1835, most of the government funds supported the study of English literature and science and the British introduced a new system of education, which discontinued the practice of supporting students of Oriental learning. Hindus adjusted to this new system of education but Muslims could not adjust themselves to this change. For Muslims, Persian was socially essential and Arabic was a religious necessity (See Chapter 1). An English class was established at the Calcutta Madrassah in 1826 and there were just 1,787 students during the next twenty four years. The English class produced just two successful junior scholars, one being Nawab Bahadur Abdul Latif. ${ }^{37}$

Committees were established to hear Muslim grievances, and recommendations were made to remove the causes of Muslim educational backwardness. The government allotted limited financial resources for poverty-stricken Muslims. Even the Haji Mohammad Mohsin Endowment was misused by the government. Abdul Latif argued that the government attempt to anglicize Muslim education failed because they did not address the needs of the community. Latif requested the government to establish an Arabic institution along with an Anglo Persian school. He also strongly suggested that English classes should be established at the madrassah, since it was an institution highly regarded by the Muslims. He wanted the government to reorganize the Anglo-Persian Department of the Calcutta Madrassah because Muslim students were at a disadvantage at the Presidency College. Muslims were unable to study Arabic at Presidency College. The new market based private model of education did not support the study

\footnotetext{
${ }^{37}$ M. Azizul Huque, History and Problems of Muslim Education in Bengal (Calcutta: Thacker Spink \&Co, 1917), $16-8$.
} 
of Arabic and Persian. Moreover, for Muslims the study of Arabic was essential. If they adopted English then they had to sacrifice Arabic, which they were unwilling to do. According to the British, English was the only language that helped Indians to progress and exposed them to Western civilization. But for Muslims it was difficult to accept. As a result, the failure to appreciate and adjust with Western civilization led to their decline. ${ }^{38}$

Along with the government, missionary supported schools also did not include Muslims. They directed their activities towards Hindus, where they were far more successful in converting Hindus to Christianity than Muslims. Moreover, the missionary schools were established in Calcutta and suburbs, which brought them in greater contact with Hindus as most of the Muslims resided in rural areas of East Bengal. (See Chapter 1 for Background) Finally, these missionary schools were mostly Bengali schools and the few English schools they had, always used Bengali as the vernacular. Bengali was a foreign language to Muslims and they were unwilling to study Bengali instead of Arabic or Persian. Fazlur Rahman argues that without Persian there was no liberal education for Muslims. Missionaries conspired against Muslims as their curriculum excluded Persian. In addition to missionary schools, the Hindu College was confined to high caste Hindus. Similarly, wealthy Hindus of Rangpur established an English school, which was restricted to high-caste Hindus. ${ }^{39}$

\footnotetext{
${ }^{38}$ Haji Mohammad Mohsin was the grandson of Aga Fazlullah, a renowned merchant of Ispahan, who settled in Murshidabad. He was born in 1710 and acquired high proficiency in Arabic and Persian. His scholarship was respected by both Hindus and Muslims. After his death in1812, his enormous property was managed by Rajib Ali Khan and Shaker Ali Khan. However, in 1814 the Government of Bengal removed them on account of misappropriation of funds, and in 1817 the property was controlled by the Collector of Jessore. The Haji Mohammad Mohsin Fund was used to improve Muslim education. The money was misused by the government and several Muslim intellectuals such as Abdul Latif criticized the government for mishandling this money. For this information, see Huque, History and Problems of Muslim Education in Bengal, 38-43; Enamul Huque, Nawab Bahadur Abdul Latif: His Writings \& Related Documents (Dacca: Samudra Parakshani, 1968), 55-77.

${ }^{39}$ See Rahman, The Bengali Muslims and English Education 1765-1835, 46-8 \& 58-61. There was a huge controversy over Bengali or Urdu being the language of the Muslims of Bengal. Dhurjati Prasad De argues that initially Muslim reformers were not much concerned about the language to propagate the ideas of the Prophet. The word Persian meant any language other than Arabic. The early reformers were more concerned about the daily prayers rather than the language. However, the situation would change in the twentieth century. Muslim lawyers like
} 
In the early nineteenth century, there were hardly any Muslim intellectuals who could urge them to study English. Moreover, the government did not have a definite education policy for Muslims until the early twentieth century. They concentrated their efforts on the Hindu College and as a result English education created a class of Hindus who acted as agents of the colonial government. Indian elites became an important factor in the administration of the country. The Public Despatch to Bengal on April 11, 1834, indicated that for the British it was best to support the Indians who started English schools by themselves. The Hindu College served this purpose very well. It gave English education to few Hindus who in turn established Hindu schools for English education. According to Rahman, "Education was indeed filtering but it was filtering in a very small measure and in the restricted field of Hindu community." (Rahman, 60) The replacement of Persian with English as the language of administration proved to be disadvantageous for the Muslims as most of them lost their jobs. The idea of improvement created unequal opportunities for Hindus and Muslims of Bengal. ${ }^{40}$

Although Anglicists emerged victorious and English education became the order of the day, the spread of education remained a major problem for the colonial government. The study of English was also made popular by a section of the bhadralok community in Bengal. The knowledge of English helped Indians to study Western science and literature, which made them appreciate British rule. However, the entire community did not adopt English readily. For example, the famous Bengali poet Rabindranath Tagore argued that Indians did not get proper education through the medium of English. They mostly memorized subjects. Moreover, orthodox families continued to oppose new ideas. But the demand and popularity of English among the

Ameer wanted his co-religionists to study Arabic, Persian, and Urdu apart from English and Bengali. But they did not deny that Bengali was the mother tongue of the Muslims of Bengal. See De, Bengal Muslims in Search of Social Identity, 98-100.

${ }^{40}$ Ibid., 58-61. 
bhadraloks was far greater than the resistance. Western education helped them to maintain their class privilege and the bhadraloks were referred to as shikkhita sampraday (educated community). But Muslims fell behind in the race. Based on Mughal tradition, Muslims continued to rely on state support. The colonial government during the first half of the nineteenth century did not pursue any education policy for the Muslims. There was not much state support for the madrassahs and maktabs. Most of the support was provided to schools, which instructed through the medium of English. However, by the middle of the nineteenth century, the colonial government realized that English education did not bring about a uniform development of the society as it was confined to a specific section. It was at this point in time that they came up with Charles Wood's Despatch of 1854 in order to provide vernacular education to a larger Bengali population. ${ }^{41}$

\section{Charles Wood's Despatch of 1854}

To understand the role that both the colonial state and the different religious communities had in implementing the colonial government's education policies, it is first important to examine the major recommendations made by Wood's Despatch of 1854 . The second age of reform was introduced by Lord Dalhousie. Dalhousie consolidated British dominion over India by his policy of annexation. He introduced railways, the public works department and appointed Sir Charles Wood to draft the Educational Despatch of 1854. Sir Charles Wood served as the Chancellor of the Exchequer from 1846 to 1852. After that he was appointed as the President of the Board of Control of the East India Company when he drafted the Educational Despatch of 1854. The despatch noted that English education had been

\footnotetext{
${ }^{41}$ See Bandopadhyay, Gopal Rakhal Dandosamas: Uponibeshbad o Bangla Sishu Sahitya, 105-7. See Chatterjee, Bengal divided, Hindu communalism and Partition, 1932-1947, 6-10.
} 
introduced in India but it was confined to a very small class of Indians. The colonial government wanted to spread European knowledge but had to devise means for imparting this knowledge to the masses. The knowledge of English was absolutely necessary for understanding European literature. However, the despatch also recognized the importance of vernacular languages and suggested that the colonial government did not wish to substitute English in place of the vernacular dialects of the country. It recommended that English would continue to be the medium of instruction for Indians who had acquired sufficient knowledge and wanted to pursue higher education, but vernacular languages would be used to educate students at the lower levels. This could be achieved by appointing English educated Indians as masters and professors of colleges who would provide instruction on European literature to their fellow countrymen through the medium of vernacular languages. Therefore, the despatch desired the use of both English and vernacular languages for the diffusion of European knowledge. ${ }^{42}$

The despatch proposed to establish an Education Department in the different presidencies of India. A system of inspection was introduced and qualified inspectors were appointed to report on the state of schools and colleges supported by the government. On the issue of developing a general plan for the development of education, the despatch observed that different experiments had been successful in different parts of the country for the encouragement of education, so there was no single scheme for the improvement of education. For Bengal, a greater cooperation between the Government of India and the Government of Bengal was needed to implement the educational efforts of the colonial state. The Council of Education proposed to establish Universities in Bombay, Calcutta, and Madras along the lines of the London University,

\footnotetext{
42 Raja Rammohan Roy, “Address dated $11^{\text {th }}$ December 1823, from Raja Rammohan Roy,” in Selections from Educational Records 1781-1839, ed. Henry Sharp (Calcutta: Superintendant Government Printing, 1920), 98-101; Sir Charles Wood, "Despatch from the Court of Directors of the East India Company, to the Governor General of India in Council (No 49, dated $19^{\text {th }}$ July 1854)," in Selections from Educational Records 1840-1859, ed. A. Richley (Calcutta: Superintendant, Government Printing, 1922), 364-93.
} 
which would consist of a Chancellor, Vice-Chancellor, and Fellows who would constitute the Senate. The universities encouraged the learning of Arabic, Persian, and Sanskrit but it did not provide funds for any teaching that opposed the principle of religious neutrality. The affiliated colleges were visited by government inspectors and scholarships were provided to students from lower schools. ${ }^{43}$.

Along with the establishment of universities, the despatch indicated that the government had made sufficient progress to place the benefits of education among the higher classes of India. This was mainly due to the fact that higher classes were both willing and able to pay for the cost of their education. But for the colonial government it was difficult to educate the masses without the support of the Indian elites. The government did not have the resources to educate such a huge population. Moreover, the elites were also interested in establishing schools for mass education not just in cities but also in remote districts. This was the most effective means to provide education to the masses. The colonial government also introduced the system of grants-in-aid, which provided aid to schools imparting secular education and remained under adequate local management like voluntary associations, private patrons, or the trustees of endowments. The government did not give aid to schools providing religious instruction. Moreover, aid was given to schools which charged fees from students and scholars. According to Wood, fees helped to appoint good quality teachers and improve the quality of education given to students. The schools that received aid from the government were subject to government inspection and had to follow any conditions laid down for the regulation of such grants. ${ }^{44}$

\footnotetext{
${ }^{43}$ Sir Charles Wood, "Despatch from the Court of Directors of the East India Company, to the Governor General of India in Council (No 49, dated 19 ${ }^{\text {th }}$ July 1854)," in Selections from Educational Records 1840-1859, ed. A. Richley (Calcutta: Superintendant Government Printing, 1922), 368-70;

${ }^{44}$ Ibid., 374-5.
} 
Closely related to the issue of inspection, the despatch desired to introduce a system of local management of schools under government inspection. It also suggested that no government institutions shall be established in districts, which had a sufficient number of institutions capable of supplying local demand for education with assistance from the state. It hoped to transfer the existing government institutions to the management of local bodies under the control of, and aided by, the state. Finally, the despatch recommended that education among lower classes can be improved through inspection and improvement of the existing schools and the establishment of new indigenous schools. It also encouraged education among Muslims and women. In conclusion, it aimed to spread European knowledge among all classes of the society through the medium of English for the higher class and vernacular for the lower classes. ${ }^{45}$

In theory, Wood's Despatch was a significant landmark in the history of education in India and documented the British belief that education should be provided to all the citizens of India. In nineteenth century Britain, the state wanted to establish a national system of education, which was free from any religious dogmas. Later the Education Act of 1870 in Great Britain aimed to provide universal education in Britain. Inspired by the British idea of improving education among masses, Charles Wood wanted Indians to be aware of European science and literature. However, he was also aware of the impact of English education on Indians. Hence, he recommended the use of vernacular languages for instruction to the masses and wanted English to be reserved for the higher classes. The despatch documented that the demand for English education was highest in Bengal. Bengalis cooperated with the British to establish five Government Anglo-Vernacular colleges and zillah (district) schools were established in every district. However, vernacular education in Bengal suffered extremely. The despatch

${ }^{45}$ Ibid., 381-2. 
recommended that the Government of Bengal should consider improving indigenous schools and education for the lower classes. Liberal ideas motivated the government to introduce the system of public-private partnerships in the field of education. Through the despatch, the British government hoped that private funds and initiative would improve the educational situation of the country. Yet, the government wanted to maintain control over the education system through the system of grants-in-aid. But the operation of Wood's Despatch brought about an inequality in the field of education as certain sections were better able to pay for their education. In the remaining sections of the chapter, the role of the colonial state and the Indians in the implementation of the despatch will be analyzed at two levels: first the influence of Wood's Despatch on the spread of vernacular education and second, the condition of Muslim education. ${ }^{46}$

\section{Immediate impact of Wood's Despatch}

Immediately after the despatch, the Hindu College was renamed as the Presidency College in 1855 and was opened to students from all religious backgrounds. New departments such as Geology, History, and Philosophy were introduced, which did not exist in the old Hindu College. However, the fee was raised from five to ten rupees, which decreased the number of students at the Presidency College. Similarly, Berhampur, Dhaka, and Krishnagar high schools were raised to the status of colleges. The Sanskrit College was affiliated with the Calcutta University and a small class of advanced students who passed the entrance examination was allowed to study Hindu logic and law. The Civil Engineering College was started in 1856 with

\footnotetext{
${ }^{46}$ The Education Act of 1870 in Great Britain recommended that all British citizens had to be educated. The act also wanted to free the curriculum from any form of religious dogmas. This approach towards education inspired the British in India to introduce a more secular form of education where grants were only given to school, which followed the policy of religious neutrality. There was a huge debate in Britain over the Education Act of 1870 . Articles published in various newspapers argued that the act was criticized for not being able to introduce a national system of education. The goal in India was to introduce a system of education, which was able to address the needs of every section of the population. But in reality, the Wood's Despatch increased the inequality in the society. Eric E. Rich, The Education Act of 1870: A Study of Public Opinion (London: Longmans, 1970), 89.
} 
the objective of training students for the employment in the Department of Public Works and Railways. Candidates had to pass the entrance examination of the Calcutta University to be admitted to the Civil Engineering College. Moreover, English classes were started at the Medical College, which included both scholarship holders and students who had to pay fees. Students had to pay an admission fee of fifteen rupees and an annual fee of five rupees. However, education reports indicate that after the despatch of 1854 , the medical college failed to produce subassistant surgeons because many students left the college before completing the program and very few students could afford to study at the college. This paucity of students forced the government to increase the number of scholarships from 50 to 59. Along with colleges, there was a demand to improve collegiate and zillah schools. The committee established to implement the recommendations of the despatch suggested that English classes had to be introduced in these schools. The committee's recommendations were approved and zillah schools were raised to the status of first grade schools in 1859. However, the Bengal government made no attempts to increase the number of English medium government schools even after the recommendations from the despatch. ${ }^{47}$

Critiquing colonial educational reforms, Gauri Viswanathan argued that Macaulay's minute paved the way for the rise of secular English education. However, these secular education policies served the need for creating a class of Indians who would act as agents of British rule. This class of educated Indians cooperated with the British to exploit the Indian resources. Moreover, the despatch called for the provision of "useful and practical knowledge to the masses." (Viswanathan, 147) This led to a stratification of Indian society. The masses were provided with basic education and were trained for specific regional needs such as agricultural

\footnotetext{
${ }^{47}$ Government of India, "Note on the State of Education in India," in Selections from Educational Records of the Government of India, Educational Reports 1859-1871, ed. Alexander. Monteath and Arthur.Pearse. Holwell (New Delhi: National Archives of India, 1960), 17-33.
} 
skills, land registration, and measurement. Simultaneously, the despatch also promoted the growth of a small intellectual class through scholarships to the Calcutta University. Students were largely drawn from educated elite families who were trained to enter government service. Viswanathan remarks, "The Despatch created a complex society through a policy of favoring differentiated education." (Viswanathan, 154) Despite the effort to spread vernacular education, English remained extremely popular after Wood's Despatch and more so after the Revolt of 1857. The government did not give education the financial priority that it demanded and the practice of charging fees was introduced. Moreover, aid was only given to those schools which charged fees from students. Education became an expensive affair and beyond the reach of many. In reality, the Wood's Despatch helped the upper and middle classes to prosper as opposed to mass education. ${ }^{48}$

Along with creating a stratified society, the popularity of English was greater than the vernacular languages after Wood's Despatch. For example, the Director of Public Instruction (DPI) in 1854 hired reformers such as Bhudev Mukhopadhyay and Iswar Chandra Vidyasagar to extend vernacular education. But, unfortunately English education was more popular than vernacular education. Shibaji Bandopadhyay argues that along with the decline of vernacular education, the teachers of Sanskrit received less respect in comparison to English. Bandopadhyay uses several primers to show that despite the effort to popularize vernacular education, English always remained popular. Bamkimchandra argued that educated Indians learned English and lived in cities whereas uneducated people who studied Bengali lived in villages. English medium schools had proper uniforms and students in these schools never thought of revolting against

\footnotetext{
${ }^{48}$ See Viswanathan, Masks of Conquest: Literary Study and British rule in India, 144-54; See Metcalfe, Aftermath of the Revolt, India 1850-1870, 130-3.
} 
their masters, teachers or principals. Moreover, in the case of higher education, students at Sanskrit College had to study Locke, Newton, and Chaucer in addition to their Sanskrit training. The bhadraloks critiqued the Bengali pathsalas (indigenous schools) and their gurus. They considered pre-colonial methods of education insufficient and corrupt. Western education through the medium of English inspired the rising Indian intelligentsia to mould themselves according to the morals and values of the Western society. Moreover, the government gave aid to schools, which provided modern education. This implied that indigenous practices were considered backward. Although the despatch aimed to promote mass education, in practice it created a small class of highly educated elite and a large number of illiterate peasants. ${ }^{49}$

Reforms such as the Wood's Despatch introduced a system of education in accordance with liberal principles. In other words, irrespective of caste or creed everybody was entitled to education but through private initiative and in partnership with state support. For example, the colonial government established a number of educational institutions, which had a fixed syllabus. Most of the textbooks glorified bourgeois attitudes and encouraged the bhadraloks to follow that. The bhadraloks also imitated the Western bourgeois attitudes and it distinguished them from the rest of the population. As a result of the Wood's Despatch, only a particular class had access to English education. Education was like a private property which could not be shared with all. ${ }^{50}$

After the Despatch of 1854, the colonial government implemented another Despatch of 1859 to review the working of the despatch of 1854 . The 1859 Despatch observed that the system of grants-in-aid created resentment among Muslims and lower class Hindus because their

\footnotetext{
${ }^{49}$ See Sengupta, Pedagogy for Religion: Missionary Education and the Self-Fashioning of Hindus and Muslims in Bengal, 47-60; See Bandopadhyay, Gopal Rakhal Dandosamas: Uponibeshbad o Bangla Sishu Sahitya, 140-63.

${ }^{50}$ John McGuire, The Making of the Colonial Mind: A Quantitative Study of the Bhadralok in Calcutta 1857-1885 (Canberra: Australian National University, 1983); 42-72; See Raychaudhuri, Europe Reconsidered: Perceptions of the West in Nineteenth century Bengal, 2; Poromesh Acharya, "Bengali Bhadralok and Educational Development in Nineteenth Century Bengal," Economic and Political Weekly 30 (1995), 670-73; See Bhattachrya, Sentinels of Culture: Class, Education, and the Colonial Intellectual in Bengal 1848-1885, 153-91; See Bandopadhyay, Gopal Rakhal Dandosamas: Uponibeshbad o Bangla Sishu Sahitya, 140-63.
} 
schools did not receive these grants. The absence of financial support limited their access to education. The colonial officers found it difficult to obtain local support for the establishment of vernacular schools under the system of grants-in-aid because there was a huge demand for English education. This circumstance made the colonial government unpopular. The despatch of 1859 went on to note that the system of private donations established and encouraged by the Wood's Despatch further aggravated class divisions in education. Vernacular education for the masses suffered due to a lack of funding. The Despatch of 1859 suggested that vernacular education had to be provided by government teachers and that lands had to be allotted at special rate for the establishment of indigenous schools. ${ }^{51}$

Similarly, William Adam in a letter to Sir John Lawrence, the Viceroy of India from 1864 to 1869 , complained that lower class children did not attend Anglo vernacular schools started by the elites. Vernacular scholarships were legally reserved for children from lower classes but in practice they were obtained by middle class students to study at English medium schools. The government spent 28,000 rupees annually on vernacular scholarships but it did not improve education among peasants. ${ }^{52}$

The sources discussed above identified several problems in the operation of the Wood's Despatch of 1854 . The responses to the reforms introduced by the Wood's Despatch were fractured. The concept of public and private partnership, which was influenced by the Victorian ideal of voluntarism, was never properly implemented to benefit the masses. Elites, especially Hindu elites, benefited from this system as they were able to take advantage of the

\footnotetext{
${ }^{51}$ W.W.Hunter, Report of the Indian Education Commission appointed by the resolution of the Government of India, (Calcutta: Superintendent of Government Printing,1883)

${ }^{52}$ William Adam and J. Long, Adam's Report on Vernacular Education in Bengal and Bihar (Calcutta: Home Secretariat Press, 1868), 27-30. Anglo-Vernacular Schools: These schools were started by Indian elites, mostly Hindus, which provided both English and vernacular education.
} 
opportunities provided by the colonial government. Yet, a large section of the Hindu population was also deprived of the benefits of education. For example, school inspectors such as Bhudev Mukhopadhyay believed that British rule was a threat to the Indians. He believed that without India it was impossible for Britain to become such a huge power. The East India Company wanted to unify, integrate, and politically develop India. This was mainly because Indian prosperity benefited Britain. But such sentiments did not last long and British rule towards the end of the nineteenth century was an expression of racial arrogance. ${ }^{53}$

Mukhopadhyay believed that English as a medium of instruction did not help Indians because the language had words, which were unfamiliar to the Indians. Through the study of English, Indians did not understand the proper meaning of Western Civilization as European teachers in Indian colleges were not proficient in Western sciences. English created a gap between the rich and poor in India. Poor Indians were harassed by the elites and in most cases the British did not care about it. To counter this racial arrogance, Mukhopadhyay suggested that Brahmanical social order helped Indians to progress. The Brahmanical social order was based on love and contentment, whereas the English society was marked by skill, efficiency, and greed. He suggested that Indians should not learn anything from the English. Western civilization lacked the high ideals of humanity. But Hindus represented a higher civilization. Tapan Raychaudhuri argues that Bhudev Mukhopadhyay was extremely conscious of his identity as a Brahman. His patriotism was not linked with political independence but wanted to preserve the Brahmanical social order. ${ }^{54}$

\footnotetext{
${ }^{53}$ See Raychaudhuri, Europe Reconsidered: Perceptions of the West in Nineteenth century Bengal, 27-92. ${ }^{54}$ Ibid.
} 
Colonial policies in terms of education had a complicated impact on the rising Hindu intelligentsia. The knowledge of English allowed the bhadraloks to imbibe and imitate the Western bourgeois attitudes. However, a significant section of Hindu community opposed new ideas. Intellectuals such as Bhudev Mukhopadhyay wanted to revive the Hindu civilization as a method to cope with Western ideas. We see a complex and a paradoxical position of the Hindu intelligentsia. Hindu revivalism, which emerged to counter Western ideas, did not campaign for political independence. The Hindu revivalists wanted to restore the Brahmanical social order, which had a strong anti-Muslim rhetoric. The approach of the Hindu revivalists will motivate the British to form an alliance with the Muslims towards the end of the nineteenth century.

\section{Impact of the Wood's Despatch continued (1854-1872)}

The despatch was severely criticized by Indian intellectuals for creating a disparity in the society. However, the minutes of the Lieutenant-Governor claimed that 228 schools were aided in twenty seven districts, which educated 16,633 pupils from the lower class. The government spent one rupee two annas for educating a student in an English medium school, seven annas for Anglo-Vernacular schools, and three annas for vernacular schools. However, the Government of India in 1859 indicated that the Bengal Government did very little to improve vernacular education. The Bengal Government argued that it was difficult for the government to maintain the cost of vernacular education as the demand for English education was extremely high. For example, even after the Wood's Despatch, zillah schools encouraged the study of English. The Anglo-vernacular schools provided English education at a cheaper rate, which prepared Indians to become inferior clerks, copyists, and hawkers. Indigenous schools in Dhaka and Jessore, which provided English education, received 1,200 rupees a year, whereas schools in Nadia, Burdwan, Hoogly, and Midnapore received 450 rupees each. Although aimed to spread 
vernacular education, the Wood's Despatch popularized the study of English to a far greater extent than the vernacular languages. ${ }^{55}$

The Education Proceedings from 1865-66 indicated that ten years after the Wood's Despatch, the higher and middle classes preferred English over Bengali. Moreover, the masses of Bengal were scarcely touched by the recommendations of the Wood's Despatch. Various plans were designed to improve the school system but the benefits were monopolized by the higher classes. The efforts to improve the indigenous village education system had failed. The few schools established by the government to improve vernacular education had reached a limited audience. In the case of higher education, the Presidency College increased its fee from ten rupees to 12 . As a result, the number of students decreased from 360 seven to 314 in 1864 . This was mainly due to the increase of fees and a large extension of colleges in the mofussils (hinterlands). In reality, prominent mofussil colleges such as the Behrampur, Dhaka, and Krishnagar included only students from the upper class. ${ }^{56}$

The failure of Wood's Despatch can also be attributed to the conflict between the Government of India and the Bengal Government. The Government of India depended on the Bengal Government and private expenditure for improving education of the masses. However, the Director of the Public Instruction for Bengal in 1864 indicated that English education improved the overall standard of the schools and the money allocated by the Government of India for vernacular education was used by the Bengal Government for providing English education. Moreover, the Bengal Government provided aid based on the following conditions: a)

\footnotetext{
${ }^{55}$ Government of India, "Note on the State of Education in India," in Selections from Educational Records of the Government of India, Educational Reports 1859-1871, ed. Alexander. Monteath and Arthur.Pearse. Holwell (New Delhi: National Archives of India, 1960), 50-2 \& 78-80.

${ }^{56}$ Government of India, "Note on the State of Education in India 1865-66," in Selections from Educational Records of the Government of India, Educational Reports 1859-1871, ed. Alexander. Monteath and Arthur.Pearse. Holwell (New Delhi: National Archives of India, 1960), 123-6, 271-2.
} 
government inspection of schools b) adequate local management of schools c) funds at the disposal of the government and d) religious neutrality. In reality, the Wood's Despatch popularized the study of English instead of the vernacular and conditions imposed by the Bengal Government forced many vernacular schools to lose their funding. ${ }^{57}$

The failure of the working of the Wood's Despatch was further confirmed by the report of Reverend James Johnston, a senior minister of the St. James Church, published in 1879. He presented a somewhat critical evaluation of 15 years of education under the Wood's Despatch. He interpreted the despatch as being comprised of three major reforms: education of the poor, the system of grants-in-aid, and the encouragement of self-help and local self government. He also estimated that between 1857 and 1866 the number of educational institutions in India more than doubled from 8,490 with 190,856 pupils to 18,563 with 590,217 pupils. This was possible due to the efforts of civil and military service members of the colonial government. But between 1866 and 1879 fewer schools were established while attendance barely doubled from 590,317 to $1,153,217 .^{58}$

Moreover, between 1854 to 1881 India had 16,649 government institutions with 769,074 students and 50,207 aided private schools with 1111,853 students. Clearly aided schools had more students in comparison to government institutions. These schools were under the control of missionaries, Indians, and private bodies that received financial aid from the colonial government. Johnston indicated that the grants were regulated by different rules in different provinces as well as by the arbitrary decisions of the provincial directors of public instruction and various people at the local government level. The government and aided schools undermined

\footnotetext{
${ }^{57}$ Ibid.; See Viswanathan, Masks of Conquest: Literary Study and British rule in India, 153-5.

${ }^{58}$ Rev James Johnston, Our Education Policy in India: A Vital Question for the Government and the Church, (Edinburgh: John Maclaren \& Son, 1879), 27.
} 
the importance of indigenous elementary schools as aided schools propagated the idea that indigenous schools provided old fashioned education, which was not suitable for seeking jobs. ${ }^{59}$

Johnston admitted that education in India was limited in nature before the introduction of colonial rule but argued that now it was greatly reduced in extent and efficiency. There were inadequate provisions for the growing population and the progressive civilization. A gap existed between the formulation and implementation of the despatch. The system encouraged investment from both Indian and foreign enterprises. Education was restricted to the upper classes and was much more difficult to access for the poor sections of the society. Finally Johnston suggested that proper management was needed to extend education to the masses. ${ }^{60}$

Although the number of educational institutions increased immediately after the declaration of the Wood's Despatch, it was mostly restricted to the upper and middle classes. There was hardly any scope for the lower classes to progress. For example, Bengal had just ten government colleges and the Government of Bengal took no steps to improve the existing situation. The Anglo-vernacular schools remained popular as the cultured class wanted to popularize their own language. But these schools were beyond the reach of the masses as they were expensive. Moreover, vernacular education for the masses did not progress and the Government of India repeatedly indicated that the Bengal Government did not implement proper policies for the spread of vernacular education. As a result of this conflict, the Bengal Government followed a very strict policy related to grants for schools. Most of the aid was given to schools, which provided English education. Education in the mid-nineteenth century meant modernization and Anglo vernacular schools were a perfect solution to it. Permanent Settlement

\footnotetext{
${ }^{59}$ Ibid., 27-30.

${ }^{60}$ Ibid.
} 
and the Wood's Despatch made it difficult to spread mass education. There was always a contradiction between humanitarian and colonial goals and the middle class had no material reasons to support mass education. The lack of any real state effort allowed private organizations based on religious affiliations and caste to establish schools for their own children. ${ }^{61}$

\section{Wood's Despatch and Muslim Education (1854-1881)}

Wood's Despatch laid down the foundation for the spread of English education in India. However, the Muslim rural population to a great extent was deprived of the benefits of English education. Even in the cities, not all Muslims were able to study in English medium schools and compete with Hindus for government employment. This disparity and the need to secure Muslim support influenced the government to reconsider its education policies towards Muslims. The Calcutta Madrassah and its Anglo-Persian Department was the only institution where Muslim boys received education and training in English, Arabic, and Persian. However, after the Wood's Despatch, the Lieutenant Governor of Bengal in 1858 wrote a minute where he wanted to abolish the madrassah and substitute it with an Arabic Professorship at the Calcutta University or Presidency College. He believed that the emphasis on vernacular education as recommended by the Despatch of 1854 did not help Muslims to progress. However, the Government of India opposed such a decision and decided to reform the Calcutta Madrassah. The Anglo-Persian department of the madrassah was raised to the status of an undergraduate college, which had only six students in 1867 . The number decreased to four in the next session. The effort to modernize the institution by introducing English did not produce effective results as Bengal Government did not allocate sufficient funds for the teaching of English. In reality, the reforms

\footnotetext{
${ }^{61}$ Government of India, "Education in British India 1870-71," in Selections from Educational Records of the Government of India, Educational Reports 1859-1871, ed. Alexander Monteath and Arthur.Pearse Holwell (New Delhi: National Archives of India, 1960), 367-8, 516-8; See Sengupta, Pedagogy for Religion: Missionary Education and the Self-Fashioning of Hindus and Muslims in Bengal, 34-9.
} 
were not properly implemented to improve either the vernacular or English education among Muslims, which affected the overall the progress of the madrassah. ${ }^{62}$

As the tension continued, Lees, the Principal of the Calcutta Madrassah, supported the Government of India and Charles Wood's decision in 1861 to continue with the madrassah in a modified form. However, the Director of Public Instruction for Bengal supported the Bengal Government's decision to abolish the madrassah. To resolve this issue, Sir George Campbell, the Lieutenant Governor of Bengal, set up a committee to review the working of the Calcutta and Hoogly madrassahs and the progress of Muslim education in general. The committee recommended that English courses would be introduced in the Arabic Department and the post of the Principal was abolished. The Bengal government in 1872 also decided to use the Mohammad Mohsin Fund for the benefit of Muslim education. The grant was to be used to maintain the Calcutta, Hoogly, and Dhaka madrassahs. A European with the knowledge of Arabic was appointed to supervise the Calcutta and Hoogly madrassahs. The Bengal Government also proposed that Muslims would be included in all grades of the Education Department and the Mohsin Fund would be used to build hostels and boarding houses for Muslim students. Based on these recommendations, it can be concluded that initially Wood's Despatch made several recommendations to improve Muslim education, but in reality there was limited progress. There was constant conflict between the Government of India and the Bengal Government over the proper implementation of the education policies. The Bengal Government was not willing to pay for vernacular education, which directly affected the position of Muslims as they demanded support for the study of Arabic and Persian. Funds were not allocated for the

\footnotetext{
${ }^{62}$ See Huque, History and Problems of Muslim Education in Bengal, 24-56. Sayyid Ahmed played a crucial role in changing British attitude towards Muslims. From 1860 to 1898 he tried to show that Indian Muslims were loyal to the British. At the same time, with the growth of national movement from the second half of the nineteenth century, British and Muslim interests coincided. The British preferred Muslims over Bengali Hindus who opposed British rule in India. For this information, see Metcalfe, Aftermath of the Revolt, India 1850-1870, 302-5.
} 
study of Arabic and Persian, which were essential for Muslims. This resulted in Muslim education suffering in several districts of Bengal. ${ }^{63}$

In addition to the attitude of certain British officials, Bengali Muslim leaders complained about the religious and cultural biases of the language readers used in government and village schools. They were frustrated with the Hindu orientation of the stories, ideas, and the pathsala curriculum. On several occasions, W.S. Atkinson, the Director of Public Instruction, noted that schools started by Muslim gentlemen had been open to boys of every creed and they employed Hindu teachers who were good managers and offered secular education. For example, Khajeh Abdool Ghani started a school in Dhaka for Muslim education, which provided education up to the entrance standard for University examination. No fees were charged and there was no discrimination on the basis of religion. Along with private educational institutions for Muslims, Charles Baron Clarke, a school inspector, indicated that the government established very few schools in East Bengal for Muslim education. The existing institutions lacked Muslim teachers, which attracted Muslim students. He suggested that Muslim schools should be established with Muslim teachers who would teach English up to the entrance standard but they would explain English in Urdu. Despite the recommendations of despatch, the demand for English education was overwhelmingly greater than vernacular education. The Bengal Government's decision to provide more funds to the study English severely affected the demands of the Muslims. Moreover, the Anglo-Vernacular schools established by the Hindus excluded Muslims. Finally, Muslims were unable to adjust to the secular education of the West. The structural problems that

\footnotetext{
${ }^{63}$ Ibid., 24-56.
} 
emerged as a result of the Wood's Despatch actually aggravated the existing inequalities in the society. ${ }^{64}$

The system to make Muslims pay for their education was severely criticized by Muslim intellectuals. Abdul Karim, a school inspector, argued that there were two problems with Muslim education: poverty and religious prejudice. Muslims mostly received religious education and poor Muslims could never pay for their education. The decrease in government scholarships with the Despatch of 1854 affected the progress of Muslim education. He recommended the appointment of Muslim officers and teachers and suggested the translation of Arabic and Persian books to English. He wanted the Bengal Government to play a significant role in order to spread education among Muslims. Similarly, H. Rickets suggested that the reforms introduced by the Despatch of 1854 were not successful as they emphasized vernacular education. He recommended the teaching of Arabic along with English as that would improve the minds of Muslims and also provide them with jobs. He asserted that for the colonial rulers, Muslim support was necessary to sustain their rule and education would make them aware of the strength of colonial rule. Wood's Despatch created a system where Indians had to undertake the duty of maintaining educational institutions. Privatization in the field of education increased despite severe criticism from the Indians. ${ }^{65}$

To resolve some of these problems, the Lieutenant Governor of Bengal in 1871, issued orders to introduce Arabic and Persian in ordinary schools wherever there was a need for it. The Calcutta Madrassah was remodeled and the Mohsin Endowment was used to improve Muslim

\footnotetext{
${ }^{64}$ National Archives of India ( Hereafter NAI), Home Department, Education, C. Beadon, Letter to A. R. Young, 1859; See Sengupta, Pedagogy for Religion: Missionary Education and the Self-Fashioning of Hindus and Muslims in Bengal, 59; West Bengal State Archives (Hereafter WBSA), Home Department. Education, W.S. Atkinson, Letter to the Government of Bengal, 12 Jan 1872, File No: 91 -95.

${ }^{65}$ Abdul Karim, Muhammadan Education in Bengal (Calcutta: Metcalfe Press, 1900); NAI, Home Department, Education, H. Rickets, Minute by Hon'ble H. Rickets, 1858.
} 
education all over Bengal. The Calcutta University decided to conduct examinations on Arabic and Persian. On the recommendations of the Governor, Calcutta University decided to include Arabic Classics in their curriculum and design proper textbooks for Muslim students. These proposals were accepted by the Government of India. M. Azizul Huque, the Joint Secretary of the Bengal Presidency Mahomedan Educational Association, indicated that the Bengal Government decided to appoint a European scholar as the Principal of the Calcutta Madrassah. The Bengal Government felt that the European Principal will have the knowledge of Persian and Arabic but will actively engage in the teaching of European Science and Arts at the Calcutta Madrassah. ${ }^{66}$

On the basis of the recommendations from the Lieutenant Governor of Bengal and Azizul Huque, three madrassahs were established at Dhaka, Chittagong, and Rajshahi. Grants from the Mohsin Fund were used to help Muslim students complete their education by subsidizing their fees. A European scholar was appointed as the Principal of the Calcutta Madrassah and the Bengal Government gave 35,000 rupees to the Calcutta Madrassah, 10,000 to the Dhaka Madrassah, 21,000 for building boarding houses for Muslim students, and 11,000 rupees for Muslim education in nine zillah schools. 11,000 rupees was used to partly pay the fees of deserving Muslim boys and maintain an Arabic and Persian teacher. Along with madrassahs, the Government of Bengal tried to mould the maktabs as primary schools by including subjects, which were close to the general system of education in the province. The government aimed to provide secular education by remodeling the maktabs. Fees were subsidized for Muslim students. Huque indicated that these policies increased the number of Muslim boys attending government and private educational institutions. But, this increase affected only a small percentage of the

\footnotetext{
${ }^{66}$ In 1870 the problems related to Muslim education attracted Lord Mayo's attention and he invited opinions from local governments to improve Muslim education. The various opinions of the local governments were published on $18^{\text {th }}$ August 1872. For this information, see Huque, History and Problems of Muslim Education in Bengal, 24-56.
} 
entire Muslim population of the province. The system of grants in-aid did not improve the overall status of Muslim education. The province had 1,287 college students of which only 52 were Muslims. Similarly, the Director of Public Instruction indicated that during the last five years 3,499 students passed the University Entrance Examination out of which only 132 were Muslims. Huque argued Muslim students were hardly visible in higher education. In 1874 Muslims comprised just four percent of the students in general colleges and 5.5 percent in special colleges. In 1881-82 it was reduced to 3.8 percent in general colleges. In government primary and middle schools, Muslims students formed just one percent of the total population. Most of the increase was at the primary stage. Huque concluded that the Madrassah Committee had lost contact with the Education Department, which had a detrimental effect on the progress of Muslim education. ${ }^{67}$

This section shows that even after Wood's Despatch, Muslims were unable to retrieve the lost ground in the field of education. They lagged behind in the field of education and employment. This lag to a great extent contributed to the beginning of the divide between Hindus and Muslims. In these circumstances, Nawab Bahadur Abdul Latif made significant contributions to improve Muslim education. He started the Mahomedan Literary Society in 1863 for the spread of Muslim education. Its office was located at his residence and met once a month to discuss the significance of History, art, geography, and business. However, people at the society spoke in Urdu, Arabic, Persian, and English, which excluded a vast population of Muslims. Rich Urdu speaking Muslims were only part of this society. ${ }^{68}$

Abdul Latif wanted Muslims to study English but he was against Western thoughts and ideas. He never wanted Muslims to boycott religious education but believed that it was useless to

\footnotetext{
${ }^{67}$ Huque, History and Problems of Muslim Education in Bengal, 24-56.

${ }^{68}$ Mohammad Abdullah Al-Masum, British Amole Banglar Muslim Sikha: Samaysa o Prashar, (Dhaka: Bangla Academy Press, 2008), 430 -6.
} 
go against the British. Hence, he suggested that Muslims should study European science and law. In 1868 at the meeting of the Bengal Social Science Association he made it clear that English education was necessary for the Muslims to progress. Although he supported the study of English and European Science, he strongly believed that madrassah education was necessary for Muslims to be accepted in their own community. But the Muslim community was divided over the demand for English education. For example, Muslim intellectuals such as Syed Aamir Hussain and Syed Aamir Ali opposed madrassah education. They believed that the study of Arabic and Persian did not help Muslims to compete with Hindus and recommended that the Mohsin Fund should be used to establish a B.A. college for Muslims next to the Calcutta Madrassah, that would provide education in English language and literature. Lastly, despite this controversy, the government strongly indicated that Muslims still preferred madrassah education hence they would continue with it and subsidized fees for Muslim students in government colleges. ${ }^{69}$

The above section shows that the intension to continue their rule in India, the colonial government decided to reconsider their education policies towards Muslims. After the Revolt of 1857, the British were convinced that Indians had rejected the benefits of European civilization. The efforts of Sayyid Ahmed and Nawab Bahadur Latif bore fruit because of their emphasis on Western education. It was more convenient for the British to support the Muslims than Hindus, who were part of the rising anti-colonial national movement. However, despite this attention to improve Muslim education, there was never any significant progress. Several committees were set up to review the progress of Muslim education but it still remained to just 3.8 percent in English medium colleges. Most of the students studied in private uninspected schools or madrassahs and received very few scholarships. High fees, religious biases, poverty, and the

${ }^{69}$ Ibid. 
lack of proper education policies forced Muslims to attend private schools. Moreover, the abrupt introduction of English created problems as they were unable to adjust to the new system of education. Only upper class Muslims could avail the benefits of English education. Overall the progress of Muslim education remained more or less unaltered after Wood's Despatch of 1854.

\section{Conclusion}

By carefully examining both the primary and secondary sources, we can conclude that there were several factors that prevented Wood's Despatch from reaching the desired target. First, the effort to spread vernacular education was severely neglected by the Government of Bengal and the Indian elites. English education remained extremely popular even after the despatch. This adversely affected the position of Muslims as they were unable to adjust to Western education instructed through the medium of English. For Muslims, the knowledge of Persian and Arabic was essential for being accepted in the community. Second, the system of grants-in-aid was not suitable for the Muslim community. Muslims were used to state support and the private system of education made it difficult for poor and rural Muslims to continue their education. Most of the scholarships were held by students from middle class families and there was a huge debate over the continuance of religious education. English classes at the Calcutta Madrassah did not have adequate numbers of Muslim students and the effort to make maktabs secular educational institutions did not produce effective results. The primary sources indicate that there was an increase in the number of students pursuing primary education but after that Muslim students were hardly visible in higher education. Scottish historian William Wilson Hunter in his book The Indian Mussalmans published in 1871 argued that the grants-in-aid system introduced by Wood's Despatch for vernacular education was quickly used by Hindus to suit the needs of their community whereas Muslims were unable to make use of such 
opportunities. Most of the aided schools were started by upper caste Hindus and they did not have any obligation to expand vernacular education to the lower caste Hindus or Muslims. Moreover, they established institutions that served the social, cultural, and economic needs of their community. ${ }^{70}$

Colonial rule extended its power over India by introducing English as the language of administration. The goal was to make Indians appreciate Western civilization and British rule. The knowledge of English helped the bhadraloks to advance under colonial rule and also maintain their class privilege. Reforms such as Wood's Despatch further popularized English education. But for Muslims, secular Western education was expensive and also conflicted with their idea of education. This inequality changed the social fabric of Bengal. Arabic and Persian were considered backward languages and Wood's Despatch further aggravated the differences between Hindus and Muslims. The absence of a centralized state education created further problems for the Muslim community. The poor and rural Muslims were dependent on the elites for education and in most cases they were unable to pay the high fees, which deprived them of the educational benefits. The solutions proposed by Nawab Abdul Bahadur Latif only helped elite Muslims to pursue English education. Rural Muslims in contrast did not receive proper scholarships to pursue their education. It can be finally concluded that Wood's Despatch increased the debates over language, religious education, and Hindu domination, which eventually strengthened the feeling of separateness. ${ }^{71}$

\footnotetext{
${ }^{70}$ W.W. Hunter, The Indian Mussalmans (Varanasi: Indological Book House, 1871), 200-2.

${ }^{71}$ See Sengupta, Pedagogy for Religion: Missionary Education and the Self-Fashioning of Hindus and Muslims in Bengal, 128-9.
} 
Chapter 3

\section{Nawab Bahadur Abdul Latif and the changing Muslim approach towards Western Education}

\section{Introduction}

The introduction of a more private sector based education under colonial rule increased inequality in education. The system of grants in-aid was unsuitable for Muslims because they were not used to paying for their education. Moreover, Muslims had no commercial interest in studying English and they still found it difficult to adjust to secular Western education. The Bengal Government struggled hard to enroll Muslim students in the English class of the Calcutta Madrassah. However after the Revolt of 1857, it was Nawab Bahadur Abdul Latif in Bengal, who played an important role in improving Muslim education. As the President of the Mahomedan Literary Society established in 1863 he encouraged Muslims to study English but opposed the abandoning of religious education. He believed that the colonial government should support both religious and secular education for Muslims. Muslims who wanted to pursue English should study in English medium schools and those who wanted to study Arabic and Persian should attend the madrassahs. This was the major difference between Latif and Fazlul Huq, the Education Minister of Bengal, who wanted to modernize the outlook of the ulemas (Muslim religious teachers) and educate both Hindus and Muslims equally. (Discussed in chapter

6) The two important Muslim intellectuals played a crucial role in improving the status of the Muslim community but their approaches toward education strengthened the demand for a separate nation as a method to improve the status of the Muslim community.

This chapter will discuss the changing Muslim approach towards Western education starting with the Revolt of 1857 . It will examine the reasons as to why they wanted to study English and what factors that still prevented them from adopting secular education. Based on the 
writings of Nawab Bahadur Abdul Latif, this chapter will also discuss extensively the role played by him and the Mohomedan Literary Association in improving Muslim education. However, it will show how his policies benefited only elite Muslims who were able to study at renowned institutions as opposed to a vast majority of Muslims who still struggled for basic education. In other words, this chapter shows how colonial education policies and the responses of the Muslim community to colonial policies in the late nineteenth century led to communal separatism in the twentieth century beginning with the Partition of Bengal in 1905. The chapter begins by briefly analyzing the legacies of the Revolt of 1857 , which will help us to understand the changing Muslim approach towards Western education. This will be followed by the condition of Muslim education after the Education Commission of 1881, and the factors that motivated them to demand separate educational institutions.

\section{Legacies of the Revolt of 1857}

By the middle of the nineteenth century, grievances against the British rule were evident in Urdu poetry and literature. For example, Khawaja Hussain Altaf Ali, in his poem Inglistan ki azzadi aur Hindustan ki Ghulami (Freedom for the British, slavery for the Indians) indicated that British rule changed India's fate. Indians became slaves with the coming of the British and they could not escape it. Similarly, Bahadur Shah Zafar, the last Mughal ruler, in his poetry also lamented about losing their Mughal lifestyle under British rule. We see that by the mid-nineteenth century poets and reformers started criticizing the British for their policies. Some of the Muslim poets, such as Mirza Ghalib and Mufti-Sadr-uddin Azurda, lamented about the deteriorating situation of the Muslims under British rule. By 1857 grievances against the British were strong and the military was no exception. In 1857 the Bengal army was no longer a strong force. The expansion of the empire across the Indus drew the sepoys (soldiers) into unknown 
territories but did not pay well for the services. The limited prospects for promotion aggravated the grievances of the soldiers. Following this, the soldiers were unhappy with the proselytizing efforts of the British officers. Finally, the cartridges of the Enfield rifle were greased with beef and pork fat, which would contaminate both Hindus and Muslims. The actual outbreak took place on May 10 at Meerut. 85 soldiers who refused to use the cartridges were sentenced to ten years of imprisonment. Fellow soldiers protested against the arrest and set off for Delhi, which they were able to capture. The fall of Delhi was followed by uprisings in the Northwest frontier province. Every class of the province of Oudh protested against the British. The revolt was brutally suppressed in $1858 .^{72}$

Following the suppression of the revolt, the British considered the Muslims as the leaders of the protest. This was mainly because Muslims were the previous rulers of the country and they wanted to overthrow the British. Metcalfe argued that the revolt cannot be considered as a Muslim conspiracy because Hindus were also hostile. For example, Rajputs provided the bulk of the leadership in Oudh. In Bengal, the Muslims remained loyal to the British. Despite loyalty, discrimination against Muslims in Bengal intensified, especially in judicial services, where Muslims held just nine out of the 284 posts in 1886. However, Muslims were able to change the attitude of the British towards them because of Sayiid Ahmed. Sayyid Ahmed, a Muslim intellectual, remained loyal to the British till his death in 1898. His work, The Loyal Mahomedans of India, published in 1860 indicated that the Muslims were the loyal subjects of the Queen. He educated fellow Muslims in Western knowledge and in 1875 he founded the Anglo-Oriental College. The Anglo Oriental College provided instruction in both Western

\footnotetext{
${ }^{72}$ See Metcalfe, Aftermath of the Revolt, India 1850-1870, 46-9. K.C. Kanda, Masterpieces of Patriotic Urdu Poetry: Texts, Translations, and Transliteration (New Delhi: Sterling Publishers Private Limited, 2005 ), 81. Khawaja Hussain Altaf Ali (1837-1914): An Urdu poet, critic, and a reformer. His famous poem Musadas-e-Hali studied the social and moral degradation of the Muslim society.
} 
education and Islamic learning. Moreover, the British and Muslim interests coincided because of the rise of the Indian national movement. The British preferred Muslims reformers over radical Hindus. After the Revolt of 1857, the British considered Indians to be backwards because they rejected the benefits of European civilization. The concept of racial inferiority was also rejected by the Indians and this started the process of opposing British rule, which took a drastic shape in the twentieth century. ${ }^{73}$

\section{The changing approach towards British rule and Western knowledge}

Hunter argued that Islam prevented Muslims from attending English schools. Moreover, they had no commercial impetus to study English. Muslim backwardness was not solely due to the apathy of the Muslims. The measures adopted by the colonial government did not attract or provide facilities to the majority of the community. For example, the downward filtration policy neglected Muslim institutions. The Bengal Government was mostly concerned about the Hindu College, which included very few Muslims. Elite Muslims used to send their children to missionary schools, which had no direct program of converting Muslims to Christianity. The English classes at the Calcutta Madrassah had very few students and the government did not take proper steps to start a new educational institution that provided English education to Muslims. Furthermore, the effort to translate English books to Persian did not produce much result as Muslims preferred to read the sacred books of their religion written in Arabic and Persian. ${ }^{74}$

Hunter further indicated that every Muslim household provided its children with religious education. After the British conquest of India, the Muslim religious institutions were ruined. The

\footnotetext{
${ }^{73}$ See Metcalfe, Aftermath of the Revolt, India 1850-1870, 300-5.

${ }^{74}$ See Hunter, The Indian Mussalmans, 156.
} 
educational system maintained by the Mughals was based on rent free grants. This was not possible under the British rule. Hunter accepted that the British policies were responsible for the decline of the community. Muslim students were unable to secure employment because they lacked the knowledge of English and this dissatisfaction turned them against the British rule. Muslim students in Calcutta were poor and were always at the mercy of some rich person. The British indifference towards the Calcutta Madrassah ruined the institution. Hunter also accepted that the grants-in-aid system introduced by the Government of India did not suit Muslim needs as the Anglo-Vernacular schools were expensive and in most cases did not provide religious education. Finally, Hunter recommended that the British government needed to educate the Muslim youth without hurting their religious sentiments. Hunter was confident that the government would take steps to improve their position and the Muslim youth would follow the path of their Hindu counterpart. ${ }^{75}$

Parna Sengupta argued that Hunter's book was written in response to the question posed by Lord Mayo who was concerned about the Muslim conspiracy to overthrow the British. Hunter felt that it was his goal to inform the British rule about the grievances of the Muslims. Hunter wanted the British state to take care of the Muslim needs otherwise they would revolt against the British. According to Sengupta, Hunter proposed religious instruction for rural Muslims and proper support for Muslim education in urban areas. Religious education would prevent rural Muslim masses from becoming fanatics and proper funding for Muslim education would make them docile colonial population. Faced by Hindu challenges, Hunter wanted the colonial state to intervene and address the grievances of the Muslims by providing them with proper education and employment opportunities. Sengupta argued that the colonial state's effort to provide better

\footnotetext{
${ }^{75}$ Ibid., 138-205.
} 
opportunities to Muslims towards the second half of the nineteenth century played an important role in changing the attitude of the Muslims towards the British. She also argued that this preference towards Muslims aggravated competition and enmity between Hindus and Muslims. ${ }^{76}$

Sengupta indicated that the policy to improve Muslim education was a response to the census statistics of 1871, which revealed that Muslims formed thirty two percent of the population in Bengal and Assam. Of this, only 14 percent of the Muslim population was literate. The number was even worse in higher education, where Muslims formed just four percent of the student population. The poor representation of Muslims in secondary and higher education motivated the British to support Muslim education. It also helped Muslims to become loyal subjects of the British rule. $^{77}$

As a result of this changing attitude, the Director of Public Instruction recommended the reorganization of the madrassahs and maktabs. In other words, the Bengal Government tried to modernize the outlook of the madrassahs as the method to improve the status of Muslim education and also make Muslims appreciate British rule and Western civilization. The government proposed that English departments at the madrassahs with an English Principal would help Muslim students to study English and improve their position in the field of jobs. Along with the proposal to modernize the educational institutions, there were demands to establish a Mahomedan College at Dhaka, where one-third of the college hours would be given for the study of Arabic and Persian and two-third for English. Finally, Muslim intellectuals and school inspectors, such as Abdool Ghani and Charles Baron Clarke, demanded that the

\footnotetext{
${ }^{76}$ See Sengupta, Pedagogy for Religion: Missionary Education and the Self-Fashioning of Hindus and Muslims in Bengal, 128-30.

${ }^{77}$ Ibid., 131-2.
} 
Education Department should include more Muslim students in all forms of government educational institutions. ${ }^{78}$.

Although Wood's Despatch aimed to spread mass education through the vernacular medium, in reality it popularized English education. The knowledge of English was necessary to secure government jobs. Failure to secure government jobs motivated Muslims to change their attitude towards secular education. Similarly, for the British it was easier to win over the hearts of Muslims than Hindus who already revolted against the British. School Inspector Charles Baron Clarke and Muslim intellectual Nawab Bahadur Abdul Latif played important roles in improving the status of Muslim education. For example, Clarke indicated that very few Muslims attended higher educational institutions as there were no Muslim teachers to attract these students. Moreover, Muslim students felt that these secular institutions, both government and aided schools, would make them kafirs (non-believers) and Hindu teachers made objectionable comments against Islam and Muslims. Primary schools had more Muslim students because they had Muslim teachers. Hence, Clarke suggested that two schools providing secondary education should be established in Dhaka and Noakhali, which would have Muslim maulvis (religious teachers) from the same districts instead of Sanskrit pundits and that these maulvis would explain English in Urdu. These teachers would exercise personal influence on the students and mobilize them to come to schools. He wanted to create an education system that suited the needs of the Muslims while at the same time modernized their outlook. Clarke believed that this approach would strengthen Muslim belief in the Western form of education and make Muslims loyal to the British. Following Clarke, both Indian English and Bengali newspapers such as the Urdu Guide and Sahachar indicated that more scholarships were needed to improve Muslim education as the

\footnotetext{
${ }^{78}$ West Bengal State Archives (Hereafter WBSA), Government of Bengal, Home Department, Education, Proceedings of the Government of India, June 1873, Proceedings 7, File No: 87.
} 
community was eager to pursue English education. In other words, Muslim modernization was linked to the idea of being loyal to the colonial state. ${ }^{79}$

Parna Sengupta through her work shows that the Bengal Government opposed Government of India's proposal to establish separate schools for Muslims. According to the Bengal Government, most of the Muslims in Bengal were cultivators who spoke Bengali just like the Hindus. As a result, between 1871 and 1880, the Government of Bengal wanted to improve the existing village pathsalas because they believed that Bengali was the language of the Muslims of Bengal. This actually countered Hunter's strategy that the state needed to distinguish between its Hindu and Muslim subjects. Sengupta argues that the Government of Bengal accepted Bengali as the vernacular for both Bengali Hindus and Muslims. However, along with village pathsalas, the Bengal Government decided to convert the lower level matabs into primary schools. This was a shift in government policy because the Bengal Government now turned religious schools into government schools and gave grants to them. This allowed them to maintain their policy of religious neutrality. The Bengal Government claimed that Muslim student enrollment increased from 14 percent in 1871 to 24 percent in 1880 by transforming maktabs into primary schools because they gained the knowledge of English. ${ }^{80}$

The effort to improve Muslim education was closely connected with the idea of providing Muslims with Western education through the medium of English. Grants were only given to schools, where English education was given the priority. The study of English was used

\footnotetext{
${ }^{79}$ WBSA, Government of Bengal, Home Department, Education, Muhammadan Education in Bengal, June 1873, File No: 87-4. Editorial, Urdu Guide Report on Native Newspapers in Bengal, July 20, 1886; Editorial, Sahachar Report on Native Newspapers in Bengal, August 25, 1886.

${ }^{80}$ See Sengupta, Pedagogy for Religion: Missionary Education and the Self-Fashioning of Hindus and Muslims in Bengal, 133-6. In 1862, Latif proposed that Bengali would be the language for lower class Muslims and Urdu for the ashrafs. However, Urduphiles in the twentieth century did not repeat Latif's proposal as Bengali was accepted as the most important language for the Muslims of Bengal. See De, Bengal Muslims in Search of Social Identity, 97-8.
} 
to modernize Muslim attitude towards the British. Vernacular education was no more given the priority by the Bengal Government. In this situation, Muslims had to study English in order to secure jobs. Here we see a shift from the recommendations of Wood's Despatch, which aimed to popularize vernacular education among the masses. But by converting maktabs into primary schools, the government increased competition because Hindus were also included in such institutions. Although Muslim attitude towards the British was changing, very little support was extended for vernacular education. In these circumstances Nawab Bahadur Abdul Latif played an important role by requesting government patronage for English, Arabic, and Persian. He also proposed separate schools for Muslims as a method to protect them from Hindu competition. In reality, separate schools aggravated the communal situation of the province.

\section{Nawab Bahadur Abdul Latif: Contributions and Criticisms}

Nawab Bahadur Abdul Latif played an important role in changing Muslim attitude towards Western education. Latif was born in 1828 and was educated at the Calcutta Madrassah. Later Latif was appointed as the Professor of English at the same institution. He believed that young men from the Muslim community should receive English education in order to avail themselves of the benefits offered by the British Raj. He dedicated his life to improving the status of Muslim education. Most of the contemporary newspapers such as the Indian Mirror, The Statesman, The Amrita Bazar Patrika and The Bengalee considered him to be a reformer because of his service to the community and education. He was considered to be a tolerant human being and a sincere friend of the Hindu community. ${ }^{81}$

\footnotetext{
${ }^{81}$ Muin-ud-Din Ahmad Khan, Muslim Struggle for Freedom in Bengal: From Plassey to Pakistan 1757-1947 (Bangladesh: Islamic Foundation 1960), 54-5; See Huque, Nawab Bahadur Abdul Latif : His Writings \& Related Documents, 111-38.
} 
Latif considered that English education was essential for Muslims to progress. According to him, the Calcutta Madrassah was the only institution with which the Muslims of Bengal identified. However, the effort to reform it did not produce effective results as the English classes were not part of the daily college routine. Moreover, he objected to the use of translated European textbooks, which he felt did not help Muslims to learn about Western science and philosophy. Latif believed that anglicizing Muslim minds would not solve the problem. He suggested that Muslims first needed the basic knowledge of English before they could learn and appreciate Western science. ${ }^{82}$

Latif's reform policies indicated that the British should first recognize and appreciate the fundamental constitution of the Muslim society. He recommended that Muslims needed to study both English and Arabic. English was necessary because it was the language of commerce and courts under British rule. According to Latif, safety and stability of life depended on British rule. As a result, he encouraged Muslims to study English. However, he recognized the significance of Arabic and Persian for a Muslim. He proposed that Muslim students should be open to learning various languages as that will broaden their horizons. Muslims who had the knowledge of both will be able to communicate to his co-religionists the benefits of British rule. He proposed to use the Hoogly Madrassah as the basis of Anglo-Persian education. The Hoogly Madrassah was founded by Haji Mohammad Mohsin but became disorganized over the years. The Mohsin Fund (started by Haji Mohammad Mohsin for improving Muslim education) maintained the madrassah and the Hoogly College. The Hoogly College provided English education and was attended by Hindu students. Latif objected to the use of the Mohsin fund for educating Hindus. The Muslim community was unhappy with the misuse of the fund. He

${ }^{82}$ See Huque, Nawab Bahadur Abdul Latif: His Writings \& Related Documents, 55-68. 
presented his views to J.P. Grant, the Lieutenant Governor of Bengal in1861, and recommended the reorganization of the Hoogly Madrassah as the basis of Anglo-Arabic education exclusively for Muslim students. Latif also proposed to discontinue the use of the Mohsin Fund for educating Hindus. ${ }^{83}$

Latif opposed the suggestions of Lees, the Principal of the Calcutta Madrassah. Lees suggested that the Anglo-Persian school should be abolished and both Hindu and Muslim students should be included in one Collegiate school. Latif believed that Muslims would have to spend their energies on studying two languages, whereas the Hindus would study one. This would demoralize Muslim students and affect their educational progress. He also recommended separate exams for Muslims. He never wanted the Muslims to go against the colonial state but demanded separate schools for Muslims as that would reduce some competition from the Hindu community. Latif preferred both English and Arabic education as he believed that would help Muslims to be modern yet rooted in their Islamic values. ${ }^{84}$

Latif's proposals were both supported and severely criticized by Indian and British intellectuals. For example, Babu Monmohun Ghose opposed the emphasis on studying Arabic. According to Ghose, Arabic was unscientific. However, Maulvi Abdullah indicated that Muslims needed to study Arabic instead of Urdu as it did not have a difficult vocabulary. Finally, Honorable Justice J. Phearson indicated that the Government should pay special attention to Muslim education as they formed half the population of the country. He suggested that the government should provide good quality English education as that would help Muslims to progress. We thus see a complicated debate surrounding the reforms proposed by Latif. Hindus

\footnotetext{
${ }^{83}$ Ibid., 194-7.

${ }^{84}$ Ibid., 39-71.
} 
opposed the study of Arabic. This opposition to study of Arabic was the beginning of Muslim alienation, which remarkably increased after the swadeshi movement. The British were not united in their response to the reforms. There was opposition to the Anglo-Persian schools. Most of British officers preferred English over the study of Arabic. However, Latif indicated that a liberal Muslim needs the knowledge of Arabic and English was needed to secure government jobs. In the larger context of colonialism, vernacular education was no longer a priority for the colonial government. The popularity and the demand for English were extremely high. Although Muslims firmly believed that religious education was necessary for maintaining their religious identity, they had to adjust to this situation in order to receive benefits from colonial rule. ${ }^{85}$

Latif's proposals were not taken into consideration for several years until the Education Commission of 1883, as Sir John Grant left for England in 1862. In 1863 Latif started the Mahomedan Literary Society, which considered India to be Darul-Islam (Country of Islam or Safety) and that Muslims were friends of the British. There was no question of declaring jihad (holy war) against them. Jihad was banned in Darul Islam and such wars would be considered a rebellion. The society helped in the progress of English education by changing the outlook of the Muslim community. They believed that by cooperating with the British, the community could improve both socially and in the field of education. The society also aimed to promote a social intercourse and interchange of thoughts among different communities of India. It made an effort to secure cooperation between European and Indian gentlemen interested in science. At the annual meetings of the Mahomedan Literary Society, discussions were held on recent scientific

${ }^{85}$ Ibid., 71-7. 
discoveries and the society was considered to be an organization that voiced the opinions of the Muslims. $^{86}$

The society also acted as a mouthpiece of the Muslim community and regularly expressed the demands of the community. For example, on the issue of improving the condition of the Calcutta Madrassah, Sir William Grey appointed a commission, which consisted of Abdul Latif, Mr. J. SuttCliff, and Mr. C. H Campbell. The Mahomedan Literary Society provided active suggestions to the committee as how to improve the quality of education provided at the Calcutta Madrassah. The society gave two annual prizes of rupees twenty each for higher education. The Literary Society also played an important role in changing the perception of the Muslim community towards Western science. Misunderstandings between the government and the community no longer existed and it fostered a feeling of harmony and good will between Muslims on one hand and Europeans, Hindus, Jews, and Parsis on the other. ${ }^{87}$

Latif's recommendations helped the Bengal Government to attract Muslim students to schools. For example, based on Latif's suggestions, the government offered a prize of rupees 100 for the best Persian essay that discussed the advantages of English education to Muslim students. This approach helped Muslims to realize the significance of English education. Moreover, he helped in the proper management of the Haji Muhammad Mohsin Fund. The endowment was initially used to educate Hindus but after his recommendations, it paid two-thirds of the fees of all Muslim students attached to English colleges. This helped Muslim students to pursue their education instead of competing with Hindus for scholarships. He was also appointed as the

\footnotetext{
${ }^{86}$ Ibid., $140-55$.

${ }^{87}$ Ibid., $152-55$.
} 
fellow of the Calcutta University and Lord Elgin indicated that the efforts of Abdul Latif and the Mahomedan Literary Society had helped Muslims to follow the path of advancement. ${ }^{88}$

On $6^{\text {th }}$ February 1882, Latif again presented his views on Muslim education at the National Mahomedan Association of Calcutta, which was formed in 1882. Latif emphasized the reestablishment of the college classes at the Calcutta Madrassah and wanted the government to maintain the college classes from the Provincial Educational Budget. Sir Ashley Eden had previously rejected this proposal but used two-thirds of the Mohsin Fund to educate Muslim students. Latif indicated that the college classes will help Muslim students to pursue English education. Second, he wanted the abolition of mufassil madrassahs. The madrassahs in the suburbs were poorly maintained and Muslims had to go to Lucknow or Delhi to study Arabic. Most of the teachers were incapable of providing good Arabic education. Finally, he proposed that the British Government should also support the study of Arabic. Arabic learning should flourish under government patronage as that will help the government to secure the support of conservative Muslims. Some of Latif's proposals were accepted by the Lieutenant Governor of Bengal. The Calcutta Madrassah was raised to the status of a college and the Rajshahi Madrassah was abolished. But Arabic learning did not flourish under British rule as the government did not allocate funds just for the study of a vernacular language. ${ }^{89}$

Latif through his reforms wanted Muslims to remain loyal to the British. He had full faith in the colonial government and strongly believed that the British would improve the position of the Muslim community. As a collaborator he held several positions under the British and was conferred the title of Nawab (King) by the Government of India because of his service

\footnotetext{
${ }^{88}$ Ibid, 164-77. Lord Elgin: A British Liberal politician who served as the Viceroy of India from 1894 to 1898. He suppressed the tribal insurrection in the North-West Frontier Province. For this information see Wolpert, A New History of India, 274-7.

${ }^{89}$ See Huque, Nawab Bahadur Abdul Latif: His Writings \& Related Documents, 164-77.
} 
to the cause of education and the improvement of the Muslim community. After his retirement he was remembered as the Honorary Secretary of the Mahomedan Literary Association and received a gold medal from Cecil Beadon. The efforts of Abdul Latif definitely paid off as a section of the Muslim population was able to benefit from the reforms introduced by the state. At the same time, these reforms helped the colonial state to produce docile subjects in the form of modern, loyal yet religious minded Muslims. Latif on several occasions was criticized for appealing to the elites. Rafiquddin Ahmed argued that Muslim families from the lower classes were unable to attend the Calcutta Madrassah and Latif himself voted against the inclusion of lower class Muslims. Admission depended on the social status of the families. ${ }^{90}$

We notice that there are two sides of the debate on Muslim education. At the beginning, the colonial government introduced a more private based system of education where Indians had to pay for their education. As a result, Muslims could not afford this new system of education under colonial rule. Along with the payment of fees, English became the most important language under colonial rule. Muslims found it difficult to study English without any state support. Most of the schools, which provided English education charged fees from the Indians. Moreover, the colonial government did not provide any support for the study of just Arabic and Persian. This had a drastic effect on the Muslim community and they fell behind the Hindus in education and employment. Even after the Wood's Despatch most of the grants were given to schools where the study of English was given the priority. The initial failure motivated Muslims to change their attitude towards English education. This was also possible because of the efforts of Abdul Latif. Latif wanted the government to support both English and Arabic education but

\footnotetext{
${ }^{90}$ Ibid,169. Rafiuddin Ahmed, The Bengal Muslims 1871-1906: A Quest for Identity (Delhi: Oxford University Press, 1981), 23 \& 36-7. Cecil Beadon: Lieutenant Governor of Bengal from April 1862 to April 1867. He was educated at Eton and served as one of the members of the British Indian Civil Service.
} 
the government did not provide financial support just for the study of Arabic. At the same time, the Muslim community was divided over their attitude towards the British policies. Latif's reforms changed the attitude of the Muslims towards the British. He tried to modernize the outlook of the Muslims and to a great extent he was successful. However, his reforms barely touched the Muslim masses. Latif worked very closely with the colonial government but they represented the needs of very few privileged men. Most of these elites wanted to secure government jobs and did not have any connection with the masses. Most of the elite institutions were located in cities; beyond the reach of ordinary Muslims. There was never any scope for pursuing Arabic education. Muslim elites had little connection with the local Muslim masses. The responses of the Muslim community to the colonial policies were also fractured. For Latif, separate institutions helped Muslims to progress. But the benefits of colonial education were never extended beyond the scope of elite Muslims. ${ }^{91}$

Although the benefits were not extended to the entire Muslim population, the Muslim elites were able to secure the support of the rural masses for separate Muslim institutions. The anjumans or private organizations played a very crucial role in mobilizing the support of the rural masses. The madrassah graduates who were mostly employed in rural areas played an important role in the Islamization of the masses. These graduates explained the tenets of Islam to the rural population through writing or by addressing religious assemblies. Cheap religious books known as nasihat namahs (Manuals of religious instruction) played an important role in Islamizing the masses. The nasihat namahs mostly wanted the rural Muslims to follow the tenets of Islam. It rejected any practices and customs alien to Islam. The tendency of the writers of the nasihat namahs was to present an inaccurate view of Islam. The urban elites such as Latif used

${ }^{91}$ See Ahmed, The Bengal Muslims 1871-1906: A Quest for Identity, 34-8. 
the Islamization to secure support for separate institutions. The Islamization of the peasantry was used very carefully by the elites to popularize the idea of an Islamic state. Unequal colonial policies coupled with intense struggle for power within the Muslim community shows the picture of a fractured Muslim community. Latif represented the demands of elite Muslims for whom separate educational institutions helped them to progress under colonial rule. ${ }^{92}$

\section{Muslim education in the late nineteenth century}

After the Revolt of 1857, the Muslim community was made to believe that they could improve their social situation by cooperating with the government. Furthermore to encourage Muslim education, the Government of India passed a Resolution in 1871, which recommended that Muslim students would receive secondary and higher education in the vernacular; the system of grants-in-aid would be extended to create English and vernacular schools and qualified Muslim teachers would be appointed in English schools in Muslim districts. To satisfy the community, the Calcutta Madrassah was remodeled and the Mohsin Fund helped Muslim students to pursue higher education. ${ }^{93}$

However, all the government resolutions did not produce effective results. The number of students at the Calcutta Madrassah between 1869 and 1870 had declined, and the results of the Bachelor of Arts. Examination at the Calcutta University was deemed unsatisfactory. The table below indicates the percentage of successful Hindu and Muslim candidates at University Examination in Bengal in 1871.

\footnotetext{
92 See Ahmed, The Bengal Muslims 1871-1906: A Quest for Identity, .

${ }^{93}$ See Shah, In Search of an Identity: Bengali Muslims 1880-1940, 82-107.
} 


\begin{tabular}{|l|c|l|l|l|}
\hline \multicolumn{3}{|l|}{ Successful Hindu and Muslim candidates at the Calcutta University Examination in 1871} \\
Examination & Hindus & Hindus & Muslim & Muslims \\
\hline Name of the & Successful & Unsuccessful & Successful & Unsuccessful \\
1871 & 504 & 859 & 27 & 44 \\
\hline Entrance Examination & & & & \\
\hline First Year Arts & 166 & 268 & 1 & \\
Examination 1871 & & & & \\
\hline Bachelor of Arts. & 56 & 95 & 0 & \\
Examination 1871 & & & & \\
\hline
\end{tabular}

(Source: National Archives of India, Government of Bengal, Home Department, Education, Education of Bengal for 1876-77, January 1878, Proceedings No: 45-48.)

Hindus were considerably more successful in comparison to the Muslims. Muslims failed at every level, especially at the final examination. This was mainly due to the decline of primary schools in districts which had a large Muslim population. Muslims criticized the British for the failings and the British authorities challenged these criticisms. For example, Mihir-o-Sudhakar criticized the Bengal Government for transferring school inspector Mr. Reuther from the Dhaka to the Orissa Circle. Reuther played an active role in promoting Muslim education. The government transferred him because Hindu intellectuals and newspapers opposed the reforms introduced by him. Rethuer was criticized for increasing the fees for examination and reexamination. This increase of fees prevented unsuccessful candidates from getting their papers 
reexamined. Throughout the colonial period financial support from the government was a debatable issue as the government was encouraging private initiative in education. ${ }^{94}$

The report of the Director of Public Instruction of Bengal recorded that between 1870 and 1871, 18.5 lakh of rupees was spent on education in Bengal. However, just three lakh was spent on vernacular education and the rest on colleges, English schools, scholarships, and school inspectors. Primary education in the province suffered. The report also stated that Muslims were hardly visible in the higher classes of government aided schools. For example, in the North Western provinces Muslims formed 14 to 16 percent of the school population and they also had several Muslim inspectors. In the case of Bengal, there were few Muslim teachers and there were hardly any Muslim school inspectors. Rajshahi was the only province, which had any substantial number of Muslim teachers. The Director urged the government to increase English and vernacular schools in Muslim districts. ${ }^{95}$

Following the resolution of 1872, Lord Ripon in 1882 appointed the Education Commission under the guidance of William Wilson Hunter to inquire into the status of education throughout India. The commission made several recommendations for improving Muslim education. First, indigenous Muslim schools would provide secular education. Second, special standards were prescribed for Muslim education and Hindustani was the medium of instruction for Muslim students except in a Muslim locality where some other languages would be adopted. However, in Muslim localities Hindustani would be a voluntary subject along with arithmetic.

\footnotetext{
${ }^{94}$ National Archives of India (Hereafter NAI), Government of Bengal, Home Department, Education, Education of Bengal for 1876-77, January 1878, Proceedings No: 45-48. West Bengal State Archives (Hereafter WBSA), Government of Bengal, Home Department, Muhammadan Education 1883, January 1883, Proceedings No: 1-2, File No: 5. Editorial, Mihir-o-Sudhakar Report on Native Newspapers in Bengal, January 12, 1900; Editorial, Dhaka Prakash Report on Native Newspapers in Bengal, January 14, 1900.

${ }^{95}$ WBSA, Government of Bengal, Home Department, Education, General Annual Report on Public Instruction, February 1872.
} 
Third, in Muslim localities funds would be allocated for the teaching of Hindustani and Persian. Fourth, scholarships would be awarded for higher education and grants-in-aid would be extended to establish English teaching schools. Fifth, Muslim teachers would be recruited and they had to give instruction in Hindustani wherever possible. Finally, the Government of India encouraged Muslims to form associations to improve the educational situation of their community. ${ }^{96}$

Based on these recommendations, the Government of India decided to give them subsidies. Moreover, the government decided to start a college for Muslims, which would provide them with higher education at a small cost. The college department of the Calcutta Madrassah was reopened in 1884 and it taught up to the First Arts Examination. It was amalgamated with the Presidency College in 1888 and this helped Muslim students to attend the lectures at Presidency College. In 1889 the Government of Bengal appointed two Muslim Assistant Inspectors of Schools to mobilize Muslims in favor of Western education. A large number of Muslims were appointed as teaching and inspecting staff. Forty-four Arabic scholarships, thirty four English, eight junior scholarships, five senior, and two postgraduate scholarships were sanctioned from the Mohsin Fund. In reality, just twenty special junior, twenty senior, and three post graduate scholarships were sanctioned by the government. ${ }^{97}$

The graph at the end of the dissertation shows a gradual increase in Muslim enrollment in primary and high schools, especially after the Education Commission of 1881. This was mainly because Muslims wanted to study English as it improved their chances of securing government jobs. Nawab Bahadur Abdul Latif campaigned for English schools in Muslim districts and the proper use of the Mohsin Fund. He also wanted the British government to

\footnotetext{
${ }^{96}$ See Huque, History and Problems of Muslim Education in Bengal, 57-66.

${ }^{97}$ Ibid., 67-70.
} 
support the study of Arabic for Muslims. In reality, financial support from the colonial state for the study of Arabic and Persian remained a problem throughout the colonial period. As a result, the enrollment at madrassahs declined. Despite the increase in enrollment in different forms of educational institutions, there was constant debate over what form of education best suited the needs of Muslims. Rafiquddin Ahmed argues that in most cases the reforms were demanded by reputable and elite Muslims who had to compete with Hindus for jobs. Hence they wanted a system which fulfilled their needs. The demands of the poor Muslim masses were ignored. For example, schools that provided both English and Arabic education were expensive and beyond the reach of many Muslims. Moreover, elite Muslims asked the government to replace Bengali with Urdu as the vernacular language. This affected rural Muslims because Bengali was the most important language for them. The nature of the rising Muslim middle class was also complicated and fractured. There was hardly any connection with the masses and Muslim elites demanded a curriculum that best suited their needs. ${ }^{98}$

Along with Latif, Justice Ameer Ali also played an important role in the spread of English education among Muslims. Ali wanted Muslims to view Islam in the modern context and train themselves to secure government jobs. He founded the Central Mahomedan Association in 1877, which aimed at political regeneration of the Indian Muslims through moral and intellectual revival. It wanted to secure government recognition and opposed madrassah education. The Central Mahomedan Association wanted Muslim students to study at the Calcutta colleges. The government responded by helping Muslim students to secure admission to the Calcutta colleges at lower fees. Along with the Central Mahomedan Association, Dacca Muslim Suhrid Sammelan

\footnotetext{
${ }^{98}$ See Ahmed, The Bengal Muslims 1871-1906: A Quest for Identity, 141-2. National Archives of India (Hereafter NAI), Government of Bengal, Home Department, Education, Education of Bengal for 1876-77, January 1878, Proceedings No: 45-48.
} 
was founded in 1883 in Dhaka for promoting Western education among Muslims. The organization continued until 1905. However, Latif opposed the abolition of madrassah education. Sir Syed Ahmed also opposed the Central Mahomedan Association for its emphasis on political activities. ${ }^{99}$

There are several aspects to the debate on Muslim education from 1870's onwards. First, religious education was an integral part of Muslim identity. However, despite several requests from Nawab Bahadur Abdul Latif the government did not provide financial support just for the study of Arabic and Persian. Second, Muslims encountered hostility and rivalry from Hindus in education and employment, which convinced them that separate educational institutions would solve their problems related to education. The demand for a separate AngloPersian school by Latif allowed Muslims to also learn English and also maintain their separate religious identity. At the same time, the demand for a separate university for Muslims increased and this was intimately connected with the founding of the Anglo-Oriental College at Aligarh in 1877. Syed Nawab Ali Chaudhuri, a London trained Muslim barrister, argued that only a separate university for Muslims would solve the problem of Muslim higher education. Initially, this proposal was not well accepted by the government and the Muslim intellectuals. However, the question of a Muslim university dominated all the Muslim educational conferences starting from 1899 onwards. The demand for separate schools came from the Muslim community. But in the larger context, the proposal for separate schools developed in response to the Wood's Despatch that resulted in unequal opportunities for Hindus and Muslims. Muslims felt that separate schools would help them to secure more support from the British and allow them to maintain their own curriculum. Moreover, they wouldn't have to compete with Hindus. The

\footnotetext{
${ }^{99}$ Chandiprasad Sarkar, The Bengali Muslims: A Study in their Politicization 1912-1929, (Calcutta: K.P. Bagchi \& Company, 1991), 7-8.
} 
effort to modernize the outlook of the Muslims was closely connected with the idea of separatism. The colonial government also supported this proposal of separate schools, which helped them to gain the loyal sympathies of Muslims. ${ }^{100}$

In the larger context, the absence of a state sponsored education under colonial rule followed by hostility from Hindus motivated Muslims to demand special favors, reservations in government jobs, and separate schools. Newspapers such as Muslim Observer and Sudhakar indicated that Muslims needed special favors because open competition with Hindus was harmful for the community. The Resolution of 1871 and the Education Commission of 1882 did not solve the problems related to Muslim education. The Muhammadan Educational Conference started by Sayyid Ahmed did very little to actually improve the educational situation of the community. It only passed a resolution against the exclusion of Persian from the university curricula. Annual meetings were held in Calcutta, Bombay, and Madras to further the scheme for a separate university for Muslims. Moreover, there were few jobs for both educated Muslim and Hindu youth. English training classes for the training of English teachers had proved to be a failure. The English classes at Hoogly were closed as there were very few people. At Calcutta, Dhaka, Cuttack, and Patna, these classes were in very bad condition. Primary teachers earned less than common laborers and in 1900 the Bengal Government reduced expenditure on education. This affected the standard of education. In 1900, an article published in the Prativasi indicated that the system of grants-in-aid increased the involvement of wealthy natives in the field of education but the number of uneducated youth still remained a problem. Private colleges maintained a poor standard in comparison to the Presidency College, which was an elite Hindu institution. Although towards the end of the nineteenth century education facilities expanded, the

\footnotetext{
${ }^{100}$ Ibid.,148-55; See Shah, In Search of an Identity: Bengali Muslims 1880-1940, 8-9.
} 
changing Muslim approach towards secular Western education was closely associated with the demand for a separate university. But these reforms affected only elite Muslims who played a crucial role in the shaping of the Dhaka University in 1921 . The Dhaka University mostly included students from the upper middle class and elite families and Muslim masses found it difficult to pay the high fees of the University. Finally, separate schools and reservations further increased Muslim alienation and started to communalize the society. ${ }^{101}$

\section{Colonial Policies and the beginning of Communal Separatism}

The system of grants-in-aid introduced a more private market based capitalist system of education, which only helped elite Muslims to secure Western education. Moreover, after the Revolt of 1857, elite Muslims were eager to study English as it helped them to collaborate and prosper under colonial rule. English education helped elite Muslims to secure power and position in the society. However, elite Muslims also demanded separate educational institutions, which they felt protected their interests under colonial rule. The emphasis on separate schools raised awareness about Muslim separate identity and distanced them from the Hindus. Syed Aamir Ali's Central National Mahomedan Association, was the first political body that represented the demands of the Muslims and safeguarded their rights. It demanded special privileges and protection from the competitive power of the Hindu bhadraloks. For example, the Central National Mahomedan Association indicated that government jobs were mostly held by the Hindu middle class. In twenty four pergunnahs (district) there were 215 officers, of which only six were Muslims. Throughout the last quarter of the nineteenth century, Muslim intellectuals and politicians complained about Bengali Hindus who monopolized government jobs. Concessions

\footnotetext{
${ }^{101}$ Peter Hardy, The Muslims of British India (Cambridge: Cambridge University Press, 1972) 138-9; See Ahmed, The Bengal Muslims 1871-1906: A Quest for Identity, 158-9; Editorial, Prativasi Report on Native Newspapers in Bengal, January 22, 1900; Editorial, Prativasi Report on Native Newspapers in Bengal, April 9, 1900. Dhaka University: For this information, see chapters 5 and 6.
} 
provided by the colonial government made English educated Muslims realize that separate educational institutions could solve their educational problems. In other words, the acquisition of English guaranteed the rising Muslim middle class certain privileges over the rural Muslim masses. Separate institutions allowed elite Muslims to continue securing the limited privileges under colonial rule. Through separate institutions, Muslims were able to maintain their separate identity but it also complicated the communal situation in the province. We will see in the later chapters that not just Hindus but also several Muslim students opposed separate educational institutions as it complicated the communal situation of the province. Secular Western education was both a form of social control and social advancement under the British rule. However, the spread of Western education did not provide equal opportunities to both communities, which in turn solidified the differences between Hindus and Muslims. ${ }^{102}$

The colonial education system promised to remove caste and religious barriers, promote social mobility, and encourage Indian participation in the administration of the country. But, historical statements such as Wood's Despatch further increased inequality in the society by making Indians pay for their education. Along with colonial rule, the Hindu revivalist movement extended its control over Bengal through the writings and teachings of Bamkimchandra, Ramkrishna Paramhansa, and Vivekananda. Towards the end of nineteenth century, Hindu revivalism played a crucial role in creating a divisive society. The emergence of Hindu consciousness also made Muslims feel that a separate university, electorates and reservation in government jobs only helped to improve their position in the society. ${ }^{103}$

\footnotetext{
${ }^{102}$ See Ahmed, The Bengal Muslims 1871-1906: A Quest for Identity, 183-90.

${ }^{103}$ Sumit Sarkar, Modern India 1885-1947 (New Delhi: Macmillan India Ltd, 1983), 70-3.
} 
The government response to separate educational institutions bore fruit, as the number of educated Muslims increased. There were occasions when Muslims attended secular schools. For example, W. S. Atkinson, the Director of Public Instruction, noted that Muslims were enthusiastic about studying in secular schools under Hindu teachers. For example, aided schools with Muslim secretaries also included Hindu students. The problem started when there were not enough jobs for the educated youth of the country. Rafiuddin Ahmed argues that the government policy of organizing Muslims only helped a select group of individuals who considered them as representatives of the community. The educated Hindus who suffered from limited opportunities, considered this policy of special privileges as a deliberate retaliation for their nationalist sympathies. The opponents of the government policies were considered public enemies. The policy of special privileges in education and government services initiated a system of segregation that continued throughout the colonial period and strengthened the separatist ideology. Finally, the special privileges were limited to the Muslim upper class and the condition of the atrap (lower class) Muslims was in no way better than the Hindu masses. The rising Muslim intelligentsia preferred only religious education for poor Muslims, which did not help them to succeed. By 1905 separatist policies had laid the foundation for the making of Pakistan and Muslim solidarity, which was popularized and manipulated even more by the religious preachers. ${ }^{104}$

This section demonstrates that with the expansion of education facilities, Muslims felt the need to study English. English education was necessary to compete with Hindus and secure jobs. However, the system of grants-in-aid made education expensive, which forced Muslim

\footnotetext{
${ }^{104}$ See Ahmed, The Bengal Muslims 1871-1906: A Quest for Identity, 133-60; Abul Kahir Nazmul Karim, “The Modern Muslim Political Elite in Bengal" (PhD diss., London School of Economics 1964), 257-335; See Sarkar, The Bengali Muslims: A Study in their Politicization, 8-9.
} 
masses to remain illiterate. The introduction of a secure system of education under private control did not influence every section of the Muslim community equally. Elite Muslims wanted both English and religious education as a method to maintain their religious identity under colonial rule. Yet, English education helped them to secure government employment. Moreover, special favors from the government in the form of separate educational institutions protected them from competition and helped them to secure and maintain a stable position in the society. Reservation of seats and the introduction of quotas for Muslims were opposed by Hindus in the twentieth century. This was mainly because of the limited number of jobs that were available during colonial rule. Hence it further increased competition for Hindus by the turn of the century. However, these reforms did not have any influence on rural Muslims as there were hardly any schools in rural areas. Along with rural Muslim students did not support the idea of separate educational institutions as they felt that it aggravated the communal and the political situation of the province. The demand for separate institutions came from elite and middle class Muslims in urban areas who needed both English and religious education to maintain their affiliation to Islam and also overcome the limitations of colonial rule.

\section{Conclusion}

This chapter shows that towards the end of the nineteenth century, there were several aspects to the issue of Muslim education. First, after the Revolt of 1857, we see a shift in Muslim attitude towards the British rule. Muslims realized that English was necessary to prosper under colonial rule. However, they also wanted to remain strongly attached to their religion for which they demanded government patronage for the study of Arabic and Persian. Muslim leaders such as Nawab Bahadur Abdul Latif demanded a curriculum that suited Muslim needs under British rule. In response to Latif's demands, the government did not provide support just the study of 
Arabic. Towards the end of the nineteenth century, we see one major shift from the recommendations of the Wood's Despatch. The government ceased to support just the study of vernacular languages as the demand for English was far greater than any other vernacular languages. Colonial rule popularized the study of English and Indian elites created a demand for it. Second, Latif also demanded separate educational institutions. Muslim leaders believed that separate institutions would protect them from the rising Hindu revivalist movement. Hindu revivalist groups opposed the killing of cows by Muslims and reservations offered in jobs and educational institutions to Muslims by the government. In these circumstances Muslims felt that separate schools and electorates protected their position under colonial rule from Hindus who were considered enemies. We notice a shift in the attitude of the Muslims towards the British and vice versa. The shift in attitude towards the British in the late nineteenth century helped Muslims to receive concessions from the colonial government. Similarly, the introduction of separate schools allowed the British to secure Muslim support for the Partition of Bengal in 1905. However, the Muslim community was not united in their support of the British. Muslim students opposed separate schools. Most of the reforms only impacted elite Muslims and there was a huge Muslim population that was still illiterate. Muslims formed just 7.8 percent of the total Calcutta University graduates. Overall the position of Muslims in Bengal did not show a remarkable improvement with the adoption of English education. They were still struggling to secure proper educational facilities for the community. The Partition of Bengal in 1905 further aggravated the communal situation of the province. The entire Muslim community did not support the Partition. The Partition was considered an act of racial discrimination and white arrogance. We get a picture of a fractured and complicated Muslim society. The change in Muslim outlook did not 
solve the problems of the community and the separatist ideology further strengthened with the rise of national education after the Partition of Bengal in $1905 .{ }^{105}$

${ }^{105}$ See Karim, "The Modern Muslim Political Elite in Bengal”, 257-335; See Sarkar, Modern India 1885-1947, 8699. 
Chapter 4

\section{Partition, Swadeshi, War, and Muslim Education, 1905 - 1921 Introduction}

After the Partition of Bengal, the demand for separate educational institutions increased in the twentieth century. Following the Partition, the swadeshi movement led to the establishment of nationalist schools, which mostly included Hindu students. However, the swadeshi movement further increased the gap between Hindus and Muslims. In these circumstances, the proposal for separate educational institutions, which came from the Muslim community, appealed to the colonial government as a feasible solution to the education problems. To the British, the Dhaka University established in 1921, was a temporary solution to the rising communal problems. ${ }^{106}$

This chapter examines how colonial education policies changed from the late nineteenth to the early twentieth century, especially after the Education Commission of 1882. It will also analyze the different changes in education policies during and after World War I leading up to the establishment of the Dhaka University in 1921. Separate educational institutions introduced by the government benefited only a section of the Bengali population. Large sections of the population, especially poor Muslims, were still deprived of the benefits of education. This history will show how the political situation of Bengal complicated the educational situation of the province. A constant conflict existed between the colonial government and the Hindu and Muslim middle classes over the formulation and implementation of educational policies. This conflict further politicized and strengthened the religious and communal differences between Hindus and Muslims.

${ }^{106}$ See Sarkar, The Bengali Muslims: A Study in their Politicization, 30. 


\section{Partition of Bengal and the Swadeshi Movement \\ Background Story}

After the Orissa famine of 1866, the Bengal government realized that it was difficult to manage such a vast province. Sir Stafford Northcote suggested a reduction in the size of the presidency for administrative purposes. In 1874 Assam was separated and made into chiefcommissioner's province and Sylhet, a Bengali speaking area was transferred along with it despite opposition from local groups. For the British, administrative concerns were most important in shaping the future map of Bengal till 1903. The undivided province of Bengal had an area of 189,000 square miles and a population of 78.5 million in 1901. Sumit Sarkar argues that the Home Proceedings and private papers reveal that political motives actually gave a final shape to the Partition plan. Lord Curzon, the Viceroy of India, in his speech at Dhaka on $18^{\text {th }}$ February 1904, declared that the Partition of Bengal would actually help the Muslims of East Bengal to unite, which did not exist under old Muslim kings and viceroys. Sarkar argues that even before Curzon several subordinate government officials wanted the division of the province along the river Hoogly. The Government of India's letter on September $13^{\text {th }} 1904$ conveyed the final draft of the Partition plan. The letter stated that Dhaka would become the provincial capital where Muslim interests would be predominantly considered. ${ }^{107}$

The final touches to the Partition plan were provided by Sir Andrew Fraser, the Lieutenant Governor of Bengal and Herbert Hope Riseley, the British ethnographer and administrator. Sarkar shows that above all it was Curzon who wanted to virtually impose the plan on Bengal. Curzon believed that if the British did not divide Bengal then the eastern part of the

\footnotetext{
${ }^{107}$ Sumit Sarkar, Swadeshi Movement in Bengal 1903-1908 (New Delhi: People's Publishing House, 1973), 9-21.
} 
province could create problems for the colonial government. Lord Minto indicated that the entire Partition was carried out with a complete disregard for local sentiments and public opinions. ${ }^{108}$ Sarkar shows that there were four trends of the swadeshi movement. First, the moderate tradition, which exposed the failure of the Anglo-Indian bureaucracy. Second, the constructive swadeshis who believed in village organizations, national education, and swadeshi enterprise to end the alienation of the elite English educated Indians. Third, political extremism, which believed in extended boycott or passive resistance. Finally, the terrorists, who demanded immediate independence through individual violence and military conspiracy. The opposition to the partition united Bengali speaking people from various fields irrespective of zamindars, lawyers, and Congress leaders. There was linguistic and literary unity and the emergence of a common culture at the village level, which included Hindu, Muslim, Buddhist, and folk elements. Along with this there were English educated bhadraloks who united against the British in Calcutta, Dhaka, Barisal, and Mymensingh. The partition was considered a humiliation after several agitations and resolutions. Political failures along with economic distress motivated the educated Bengali youth to glorify the past. This search for the past led to Hindu revivalism. The educated Bengali youth claimed that the achievements of modern science were known to ancient rishis (saints) and Bakimchandra's Anandamath was the gospel for Bengali youths. The ground was well prepared for the rise of new radical politics. However, Sarkar indicates that the antiBritish sentiment was confined to elite Hindus. The emphasis on self-reliance was identified as the structure for the rise of extremism. Extremists attacked moderate Congress leaders for being denationalized Anglicists. Religion was used to bridge the gap between the elite and the masses. Religious revivalism along with the rise of social extremism deepened Muslim alienation.

Moreover, after the Mymensigh riots in 1906-07, Muslim peasants turned against the immediate

${ }^{108}$ Ibid., 18-20. 
oppressor, which was usually the Hindu zamindar or the swadeshi leader. According to Sarkar, the failure to integrate social and national discontent further alienated Muslims. ${ }^{109}$ Against this background, the next few sections will show the impact of the partition and swadeshi movement on Muslim education.

\section{The Crucial Years 1900-1914}

\section{A) Years leading up to the Partition in 1905}

The first few years of the twentieth century leading up to the Partition in 1905 witnessed the introduction of several educational reforms. In 1901 the Government of India sanctioned a grant of ten lakh rupees a year for the purpose of education. Primary sources indicate that despite the sanction of the grant, not many reforms were introduced in the first year. In the second year the Government of Bengal decided to use the grant for providing stipends to primary school teachers based on the results of their periodical examinations. A sum of 400,000 rupees was used from the imperial grant to cover the increased expenditure for stipends to primary school teachers. At the same time, the government decided to increase the number of aided pathsalas. At the end 1904, Bengal had 43, 950 schools with 1286,787 students as against 36,312 schools with 1024,198 in 1902 . There was an increase of 7,638 schools and 262,591 students in two years. ${ }^{110}$

The Education Commission of 1882 desired greater cooperation between the government and private associations and by the turn of the century, the government also encouraged the establishment of more aided schools. Private initiative in education increased the number of aided and unaided institutions but this proved harmful for the actual education of Indian students. Private schools and colleges maintained a low standard of education, fees were high, and most

\footnotetext{
${ }^{109}$ Ibid., 31-91. Sumit Sarkar, A Critique of Colonial India (Calcutta: Papyrus, 1985), 42-3.

${ }^{110}$ West Bengal State Archives (Hereafter WBSA), Government of Bengal, Home Department, Education, Proceedings of the Hon 'ble Lieutenant Governor of Bengal, July 1905 Proceedings No: 25, File No: $10-\mathrm{C} / 1$ 16.
} 
poor families were deprived of the benefits of education. For example, most of the scholarships offered by the government were held by students from government colleges, especially those studying at Presidency College. The number of successful students in government colleges increased by 1.4 percent whereas it decreased by 1 percent in aided, and 4.8 percent in unaided colleges. Additionally, the increase of fees forced Muslims to leave elite institutions including the Presidency College. ${ }^{111}$

Along with privatization of education, the Director of Public Instruction transferred the management of government colleges and schools to local private bodies. This helped Curzon to raise college fees, which affected enrollment in schools and colleges. Following the transfer of the management of government colleges, Lord Curzon introduced the University Act of 1904. The act reduced the number of elected members in the Senate and curtailed the independent powers of the Calcutta University in matters of granting affiliation to colleges. He also abolished public or competitive examinations. Public examinations were held at high school level to secure government scholarships for studying at the Calcutta University. In its place, he introduced a system of private school tests where only talented students competed for scholarships. Private examinations were mostly oral and boys were selected on the basis of grades. This made it difficult for students from different economic backgrounds to secure scholarships. The reforms introduced by Curzon did not produce effective results and were severely criticized by contemporary newspapers. For example, the Daily Hitavarda condemned Curzon's educational policies. According to this native owned English newspaper, the number of young Indians receiving higher education between 1893 and 1894 was 14,500. The number increased to 19000

\footnotetext{
${ }^{111}$ WBSA, Government of Bengal, Home Department, Education, Report of the Educational Improvements resulting from the Imperial Grant of rupees ten lakhs, July 1905, File No: 10-C/1 14. WBSA, Government of Bengal, Home Department, Education, Report of the Director of Public Instruction 1904-1905, December 1905, Proceedings No: 25-6, File No: 8-R/3 15.
} 
in 1900. However, this slow progress was halted by the University Act of 1904, which made it difficult for common Indians to attain higher education. However, Curzon believed that these reforms improved the standard of education in Bengal. ${ }^{112}$

In addition to the reforms introduced by Curzon, the Director of Public Instruction responded to some of the demands by the Muslim community. The government encouraged the establishment of maktabs and madrassahs as a method to improve education among the community. More emphasis was placed on religious education and Muslims were encouraged to study religious texts. However, the colonial government only supported schools, which followed the principle of strict religious neutrality and most of the government jobs still required the knowledge of English. In other words, the demand for religious education did not receive state support even in the twentieth century. But the colonial government suggested that private associations and individuals had to establish English medium schools for Muslims. ${ }^{113}$

The debate on colonial education became further complicated in the twentieth century. First, by the early twentieth century, far greater emphasis was placed on privatizing education. The government strongly encouraged the establishment of aided and unaided schools. For example, Bengal had a total of 60,322 private and 51,675 public educational institutions for men in 1905. Similarly, the province had just 4,984 public and 5,232 private institutions for women. Private institutions mostly supported the education of the masses. Second, the government encouraged religious education for Muslims but maintained the policy of religious neutrality when it came to supporting schools. The government mostly wanted private individuals and

\footnotetext{
${ }^{112}$ WBSA, Government of Bengal, Home Department, Education, Report of the Director of Public Instruction 19041905, December 1905, Proceedings No: 25-6, File No: 8-R/3 15; Editorial, Daily Hitavadi, Native Owned English Newspapers in Bengal, May 3, 1905; Editorial, Daily Hitavadi, Native Owned English Newspapers in Bengal, May $7,1905$.

${ }^{113}$ See Sarkar, Modern India 1885-1947, 105; WBSA, Government of Bengal, Home Department, Education, Report of the Director of Public Instruction 1904-1905, December 1905, Proceedings No: 25-6, File No: 8-R/3 15.
} 
associations to support Muslim education. There was also a decline in government expenditure on education in 1905 from rupees 13865,410 to rupees $13789,560 .^{114}$

The colonial education system was expensive and beyond the financial capacities of a substantial section of the population. The public-private partnership in education introduced by the Wood's Despatch of 1854 was gradually moving towards complete private control in the twentieth century. This adversely affected the admission of students as fees increased in government and aided schools. Competition increased in the field of education as private schools and scholarships were mostly restricted to students from affluent families. Poor families found it difficult to continue their children's education. In these circumstances, elite and middle class Muslims had access to education but poor Muslims were still deprived of the benefits of education. Moreover, in the case of Muslim education, schools which provided just religious education received very little financial support from the government. The effects of the private system of education were becoming evident and over the next few years we see intense conflict within the Muslim community over the policies introduced by the colonial state.

\section{B) Partition and its influence on education}

According to Curzon the territorial reorganization of Bengal was important as it reduced the burden of the Government of Bengal. Curzon suggested that Chittagong, Dhaka and Mymensingh (districts in Eastern Bengal) were to be transferred to the Assam province as it improved the administrative situation of Assam. The partition reflected the colonial government's indifference towards the dreams of bhadraloks. By transferring most Muslims to East Bengal and Biharis and Oriyas to West Bengal, the colonial government wanted to form an alliance with the different communities. But the government ignored the social and political

\footnotetext{
${ }^{114}$ WBSA, Government of Bengal, Home Department, Education, Report of the Director of Public Instruction 19041905, December 1905, Proceedings No: 25-6, File No: 8-R/3 15.
} 
situation of the province, and the partition gave rise to the nationalist movement for which they were not prepared. ${ }^{115}$

Scholars are divided in their opinions over the Partition of Bengal in 1905 and its influence but it was evident that the incident had a complicated and depressing influence on contemporary Indian society. For many it opened the doors for progress and for others it brought economic hardships. The Central National Mahomedan Association and the Dacca Muslim Suhrid Sammelan opposed the partition. Initially, Nawab Bahadur Salimullah of the Dhaka Nawab Family also opposed the partition. But after Lord Curzon's speech on February 18, 1904 Muslims were divided in their response to the partition. Curzon announced that Dhaka would be the capital of East Bengal and Muslims would enjoy a larger share in government services and educational institutions. This announcement motivated loyalists and aristocrats such as Nawab Bahadur Salimullah and Nawab Syed Nawab Ali Chaudhuri of Dhanbari Mymensingh, to support the Partition of Bengal. The Muslim Literary Society established by Abdul Latif advised Muslims not to attend any political meetings or demonstrations organized by the Hindus. The partition was supported not just by the educated Muslims of East Bengal but also by some of their co-religionists in Calcutta. However, Muslims who opposed the partition believed that the new province of East Bengal and Assam influenced the socio-economic position of Muslims in West Bengal as they were reduced to the status of a minority. Finally, Abdur Rasul, a Muslim lawyer, suggested that the partition increased the distance between Hindus and Muslims. Rasul believed that Muslim education would suffer in the new province. This was predominantly because it would take time for the new reforms to be successful. Similarly, renowned Muslim families such as the Khaja family believed that the partition had a negative influence on both

\footnotetext{
${ }^{115}$ J.H.Broomfield, Elite Conflict in a Plural Society: Twentieth Century Bengal (Berkeley: University of California Press, 1968), 27-9.
} 
Hindus and Muslims and so it had to be revoked. The anti-partitionists formed an organization called the Bengal Mahomedan Association in 1906 and Abdur Rasul was the President of the organization. The organization promoted communal harmony in the struggle against foreign rule. However, the organization was limited in its activities. ${ }^{116}$

In this difficult political situation, the Government of Bengal did not introduce any new policies but continued to follow a strict policy for providing grants to educational institutions. The amount of grant depended on the quality of the faculty and the fees imposed on students. Aided schools had to maintain the following: an admission register, an attendance register for teachers and scholars, a diary, a visitor's book, and a cash book that recorded scholarships given to students and payments made to teachers or students Second, a school had to maintain a register recording all the transfer certificates issued and received, service books for teachers, which had to be frequently updated, a record of university examinations, proceedings of the management committee, and corporal punishment inflicted on students. Third, the principals had to record visits of school inspectors and managers, appointment and resignation of teachers, and also the progress made by students of each class. Grants were given on the basis of religious neutrality and the amount of fees charged from scholars. Fourth, schools had to provide mandatory instruction in art, drill, and gymnastics. Graduate trained teachers after passing the oral examination in English were appointed to teach all subjects in English. Finally, financial aid from the colonial government did not exceed half the income guaranteed from private sources, and grants were usually made for three years but school inspectors had the right to renew the grant on special recommendations. ${ }^{117}$

\footnotetext{
${ }^{116}$ See Sarkar, The Bengali Muslims: A Study in their Politicization 1912-1929, 21-5; See Ahmed, Muslim Community in Bengal 1884 -1912, 251 -9.

${ }^{117}$ WBSA, Government of Bengal, Home Department, Education, Rules for grants-in-aid to schools in Bengal for Indian pupils, 1905, File 10-C/1 14.
} 
Although Lord Curzon claimed that East Bengal would provide additional opportunities for Muslims, the rules for securing grants remained unchanged. The policy of public-private partnership in education was gradually moving towards complete privatization of education. The reforms introduced by him provided limited grants to specific schools, which further complicated matters. In addition to privatization of education, the language of instruction still seemed to be a problem for the government. The Wood's Despatch recommended the use of vernacular for masses and English for the elites. In reality, the government preferred vernacular as the medium of instruction in primary and middle schools and English for high schools even after the partition. This automatically decreased enrollment, as Bengali students found it difficult to adjust to a foreign language in higher classes. To complicate matters further, the colonial government wanted to publish Bengali textbooks for primary schools in four provincial forms of the Bengali language. This division of the Bengali language at the primary level had a negative influence on the society. It was difficult to educate students as there was no uniformity in the curriculum of primary schools. The new textbooks reduced the enthusiasm for education, teachers were poorly paid, and gurus were unable to teach the new subjects introduced. Bengali babus (upper middle class intellectuals) such as Pyari Sarkar Dasgupta accused the government of crippling the Bengali language and dividing Bengal. According to Dasgupta, the colonial government had minimum knowledge about Bengali but they prescribed text-books in Bengali. $^{118}$

By publishing Bengali textbooks in different dialects, the government hoped to popularize Bengali among the masses. But the effort to popularize Bengali among the masses did not produce effective results. The demand for English was far greater than Bengali. Moreover,

118 “Text-Books for rural schools,” Kasipur Nivasi, April 1, 1905, No.13; Editorial „Daily Hitavadi, Native Newspapers in Bengal April 10, 1905;. Babu Pyari Sarkar Dasgupta, "Vernacular text-books for primary schools." The Sanjivani, Report on Native Newspapers in Bengal March 22, 1905. 
knowledge of Bengali at the primary level made it difficult for the Bengali youth to secure jobs, which required the knowledge of English. As a result, Muslim boys preferred to study English. These reforms further made it difficult for the masses to secure jobs and employment.

Native owned English newspapers such as the Hindi Bangavasi, Sandhya, Basumati, and Dhaka Prakash had criticized the government, especially Lord Curzon, for introducing such dubious policies. He was considered an autocratic ruler and all departments including education was under his strict control. ${ }^{119}$ His policies of affiliating colleges controlled by a governing body appointed by the British, and apparently increasing grants for Muslim education was an effort to strengthen British rule. The textbooks were also criticized for publishing communally provocative statements that the editorials felt were unsuitable for the Muslim population. For example, The British Indian Association argued that the textbook "Sisubodh" (Ideas and Morals of a Child) prescribed for rural education was written from a communal point of view. ${ }^{120}$

John Berwick in his $\mathrm{PhD}$ thesis argued that Curzon's education policies were "designed to limit the emergence of concentrations of indigenous power within the framework of imperial rule.” (Berwick, 123) Curzon believed that proper organization of education was necessary to continue colonial rule. This idea to a great extent was linked to the Partition of Bengal, which he considered would help in the proper development of Assam and East Bengal. Curzon indicated that the colonial system of education satisfied the aspirations of the students and the government had access to intelligent public servants. The strict policies forced Indians to realize the true benefits of education. However, Curzon's education policies proved to be a failure as the number of successful candidates in school and university examinations decreased among Indians. Students from rural areas were unable to adjust to English in higher classes. It

\footnotetext{
${ }^{119}$ Editorial, The Sanjivani, Report on Native owned English Newspapers in Bengal June 29, 1905.

${ }^{120}$ Editorial, Mihir-o-Sudhakar, Report on Native Newspapers in Bengal March 24, 1905.
} 
became increasingly difficult for the students to cope with this change from primary to higher education. Lastly, textbooks with communal overtone encouraged Muslim separatism. For the politically conscious educated bhadraloks, the Partition of Bengal was a major humiliation, which provoked widespread anger and patriotic outburst. ${ }^{121}$

In this situation, the Hindu middle class supported the rise of nationalist schools but the state of Muslim education was more complicated. The first two decades of the twentieth century witnessed a constant conflict and to some extent cooperation between the colonial state and the Muslim middle class. This form of cooperation over education polices played an essential role in solidifying Muslim separatism. The next section evaluates the influence of the partition on Muslim education and shows how the political events of the period strengthened separate identities.

\section{C) Partition, Swadeshi, and Muslim Education (1907-1912)}

Immediately after the Partition, there was a considerable increase in the number of Muslim students in East Bengal from 1907 to 1912. At the primary stage, an increase of 53 percent of Muslim students was recorded by the colonial government, while at the secondary stage the number of educated Muslim increased from 27 to 36 percent. The total number of educational institutions for Muslims, both public and private, increased from 22,141 to 24,550. In Chittagong, Dhaka, and Rajshahi, the number of public institutions increased by 12.6, 15.2, and 1.9 percent respectively. The number of pupils learning English in public schools increased from 72,019 to 140,235 . This was mainly due to two reasons: admission of students in the middle classes of high schools and the teaching of English in unaided schools. According to the

\footnotetext{
${ }^{121}$ John Berwick, "Chatrasamaj: the Social and Political Significance of the Student Community in Bengal 1870 1922” (PhD diss., University of Sydney, 1986), 124-8; 9-30. See Sarkar, Swadeshi Movement in Bengal 1903-1908, 9-30.
} 
government, this was possible because Muslims realized the importance of education. Education was gradually becoming more popular among Muslims. ${ }^{122}$ The colonial government increased expenditure on Islamic primary education by 57 percent. Urdu was introduced at the primary level of middle madrassahs. The partition gave some relief to Muslim peasants who lived under Hindu landlords. The colonial government sanctioned 250,000 rupees as loans to the Muslim peasants of Mymensingh in East Bengal. For a brief period of time it appeared that Muslims benefited from the Partition of Bengal. ${ }^{123}$

Similarly, the report of the Director of Public Instruction for East Bengal and Assam indicated that after the Partition of Bengal, the quality of educational institutions improved in East Bengal and Assam. Most importantly, there was introduction of Board Schools in East Bengal. An imperial grant of three and half lakh rupees was used to build Board Primary Schools. These schools were maintained by special capitation grants made at the end of the year. The success of the system encouraged proprietors and tenants to allow the government to build schools on their lands. Following primary education, higher education also improved after the Partition in East Bengal. The government colleges were more active than aided or unaided institutions. There were four government colleges: Chittagong, Dhaka, Rajshahi, and Cotton College in Gauhati. The Dhaka College was one of the premier institutions in East Bengal that offered specialized courses in History and Political Economy. The educational infrastructure improved at Brojomohan, Jagannath, and Rajshahi colleges. New laboratories were built, libraries were improved and government colleges provided instruction up to the BA standard.

\footnotetext{
${ }^{122}$ WBSA, Government of Bengal, Home Department, Education, Government of Bengal, Report on the Progress of Education in East Bengal and Assam for the Years 1907-12, Proceedings No: 1-3, File No: 8-R/16 2,1907.

${ }^{123}$ See Sarkar, The Bengali Muslims: A Study in their Politicization 1912-1929, 30 -3.
} 
The report confirmed that good quality education was provided in East Bengal after the partition. $^{124}$

Along with primary and higher education, the report of the Director of Public Instruction for East Bengal and Assam further claimed that madrassah education also improved. Most of the madrassahs were aided institutions. The number of unaided madrassahs decreased as they accepted grants-in-aid from the government. There were only two government madrassahs: Chittagong and Dhaka. They were maintained by the Mohsin fund. Instruction was provided in Arabic up to the matriculation standard. Mr. R.S. Greenshields, the President of the Chittagong Madrassah Committee, recommended that the government had to reserve scholarships for Muslim students as it was possibly the only method for poor students to continue their education. Maktabs recognized Bengali as the vernacular of the Muslims living in East Bengal. Urdu was also introduced as a separate subject. Several private organizations such as the Tippera Muhammadan Educational Society worked towards improving Muslim education. The report of the Director of Public Instruction indicated that the colonial government introduced several policies to improve Muslim education and some Muslims enjoyed the benefits offered. Newspapers such as the Soltan praised the government for the reforms introduced after partition. Soltan insisted that Muslims should not join the swadeshi movement, which started immediately after the partition, as it hindered the progress of Muslim education. ${ }^{125}$

Along with support to government policies, Muslim backwardness in comparison to the Hindus motivated a small section of the Western educated Muslim population to support the government. For example, opinions of Muslim intellectuals published in various newspapers and journals supported government's decision to partition Bengal. The Mussalman suggested that it

\footnotetext{
${ }^{124}$ WBSA, Government of Bengal, Home Department, Education, Report on the Progress of Education in East Bengal and Assam for the Years 1907-12, Proceedings No: 1-3, File No: 8-R/16 2.

125 Ibid.
} 
was the duty of the colonial government to reorganize and improve maktab education. Following the Mussalman, the Soltan indicated that Hindus monopolized arts and industries and so Muslims should study abroad in order to progress. The editor of Procharak recommended that Muslims needed to study Arabic and Persian, History, Geography, and Physical Science in order to progress. Intellectuals emphasized rigorous religious instruction in both private and government madrassahs. $^{126}$

The Muslim community was not united in their responses to the partition and the educational reforms introduced in East Bengal after 1905. A large section of the anti-partionists argued that the Partition of Bengal increased the differences between Muslims of eastern and western parts of Bengal. Muslims in West Bengal were treated as minorities and Muslims from East Bengal were not allowed to participate in educational conferences held in West Bengal. Muslims from East Bengal demanded a share in the Mohsin fund and the colonial government responded by throwing open the Mohsin Fund scholarships to the Muslim students of both the provinces. $^{127}$ This increased competition over the limited number of Mohsin Fund Scholarships. As a result very few Muslims had access to scholarships to pursue higher education. For a brief period of time, education among the Muslim community progressed after the partition. The expenditure on education increased from 20 million rupees in 1903 to 24 million rupees in 1906. ${ }^{128}$ This slight increase was not really sufficient for the community.

Anti-Partitionists views were also published in newspapers such as the Sanjivani. For example, an article published in Sanjivani in 1908 observed that education was the chief factor for national progress. The early English rulers provided equal education to Indians but

\footnotetext{
${ }^{126}$ Editorial The Mussalman Report on Native Newspapers, April 24, 1908; Editorial The Soltan, Report on Native Newspapers, April 24, 1908.

${ }_{127}$ See Sarkar, The Bengali Muslims: A Study in their Politicization 1912-1929, 35.

${ }^{128}$ See Sarkar, Modern India 1885-1947, 105 -6.
} 
Lord Curzon blocked the path of progress in order to keep Indians subdued. Many schools were closed because they were unable to bear the increased expenditure. Curzon wanted to increase the expenditure for schools but never mentioned a method to improve the income of the school. Fees were increased and this resulted in greater hardship for Muslim students. According to Mr. Darbar Ali Biswas, a Muslim thinker, Lord Curzon narrowed the chances of educational progress for Muslims. Grants-in-aid from the government declined and Curzon recommended expensive textbooks, which had a negative impact on the Muslim community. The admission procedures were complicated and public exams were abolished. All these reforms aggravated the problem as most Muslim students lost the incentive to study. ${ }^{129}$

The anti- partitionists were also critical of the policy of divide and rule. Newspapers and editorials supporting the anti-partionists claimed that a very large section of the Muslim community was still suffering, especially; those living in rural areas as there were not enough schools in such areas. The scholarship examinations were held at a central place and it was difficult for poor students to travel to distant places. ${ }^{130}$ The Education Department increased fees, which made it difficult for Muslims to send their children to school. The Department required students to pay six months fees at the beginning of the term. This forced students to leave school. Most native newspapers published in English claimed that the colonial government made education extremely expensive for the poor inhabitants of the country. ${ }^{131}$

Along with the anti-partionists, several government and newspaper reports gave an impression that reforms were never properly implemented, and those implemented benefited

\footnotetext{
${ }^{129}$ Editorial The Sanjivani, Native owned English Newspapers in Bengal, July 16, 1908; Editorial, The Sandhya , Native owned English Newspapers in Bengal, . March 8, 1905; Editorial, The Nihar Native owned English Newspapers in Bengal, August1, 1905.

${ }^{130}$ Editorial The Nihar, Native owned English Newspapers in Bengal,April 8, 1905.

${ }^{131}$ Editorial, The Dacca Prakash, Selections from the Anglo-Vernacular Newspaper in Eastern Bengal and Assam, 1911.
} 
only a few. The colonial government encouraged English education among the Muslims. But this was not enough to address or reduce the grievances of the Muslims. There were hardly any provisions for the teaching of Arabic and Persian. The educational policies pursued by the colonial state increased the gap between the rich and the poor in the Indian society. Primary education was suffering, the system of examination was abolished, teachers never received proper salaries, and textbooks were published in different dialects of Bengali, which adversely affected the progress of education among Muslims. Although some of the problems were recognized by the government, there were never any substantial changes in the policies. The immediate increase in the number of students and educational institutions helped only a section of the Muslim intelligentsia to progress under colonial rule. A vast section of the Muslim population was deprived of the benefits of education. This deprivation constantly fueled communal feelings as various policies formulated by the colonial government failed to improve the situation of poor Muslims. The policies introduced not only influenced education but also paved the road for the rise of separatist politics (discussed later). ${ }^{132}$

The Muslim opinion towards the educational reforms was thus extremely fractured. This also reflects the presence of several voices within the Muslim community. Towards the end of the nineteenth century, a section of the Muslim population supported the study of English as it helped them to progress under colonial rule. This group of men supported the Partition of Bengal, in the hope that it would protect them from Hindu oppression. However, elite contact with the masses was negligible and they had very little idea about the problems faced by Muslims living in the rural areas. After the partition there was an increase in the number of educational institutions but these institutions were mostly established in urban localities and

\footnotetext{
${ }^{132}$ See Sarkar, Modern India 1885-1947 (New Delhi: Macmillan India Ltd, 1983), 122-3. See Shah, In Search of an Identity: Bengali Muslims 1880-1940, 100-1.
} 
students from rural areas had no access to them. Most elite Muslims suggested that religious education best suited the masses in rural parts of the province. This was mainly because elites wanted to prevent the spread of Western education among the rural masses as they were afraid of competition. Suchetana Chattopadhyay in her dissertation argued that a large number of students came to Calcutta from the mufassils to study in the colleges of Calcutta. Students from outside Calcutta held on to their district, communal, ethnic, caste, and provincial affiliations. Muslim students from outside Calcutta found it difficult to secure housing and this forced many Muslim students to leave their studies and return home. Hindu landlords refused to offer housing to Muslims students. But such incidents were nothing new and communal prejudices of the Hindu bhadralok society persisted for years even before the swadeshi movement. ${ }^{133}$ It was difficult for Muslim students to attain admission in Presidency College, one of the elite institutions of the period supported by state patronage. Only thirty five Muslim students were admitted as a compensation for abolishing the college classes of the Calcutta Madrassah. ${ }^{134}$ Chattopadhyay showed that Muslim students took admission in second rank colleges such as the Bangobashi College Calcutta, established by Indians and dependent on fees from students. ${ }^{135}$ Curzon's repressive policies coupled with the discriminatory approach of national education forced Muslim students in Calcutta to study in second grade colleges. The debate within the Muslim community shows the existence of limited opportunities and intense competition under colonial rule.

The conflict within the Muslim community over the reforms introduced during and after the partition also coincided with the rising swadeshi movement. The national or swadeshi education primarily focused on literary and scientific education, which did not appeal to the

\footnotetext{
${ }^{133}$ See Chattopadhyay, "Muzaffar Ahmad, Calcutta, and Socialist Politics, 1913-1929," 33-4.

${ }^{134}$ Editorial, The Mussalman, July Report on Indian owned English Newspapers in Bengal, July 4, 1913.

${ }^{135}$ See Chattopadhyay, "Muzaffar Ahmad, Calcutta, and Socialist Politics, 1913-1929," 33-4.
} 
masses. Traditional cultural prejudices and biases were strongly imposed on higher education. The nationalists believed that Western education was uprooting Indians from their traditional religion and values. For the nationalists the slogan for the day was "on national lines and under national control." (Sarkar, 154) Nationalists encouraged Indians to return to tols and pathsalas where ‘Aryan knowledge' would predominate. However, for poets such as Rabindranath Tagore, national education meant developing the indigenous resources of the country instead of opposing foreign rule. But for most nationalists, national education included industrial training along modern lines. Boycott of educational institutions started immediately after the partition. Repressive measures were used by the government to suppress student demonstrations, which took the shape of mass protest and boycott. ${ }^{136}$

Students pursuing national education at higher level were unable to secure employment. This was mainly because government jobs required the knowledge of both science and humanities, which were not provided in national schools. National technical education did not prepare students for government jobs. Except for institutions such as the Shantiniketan, established by the famous poet Rabindranath Tagore, most national schools recruited students for revolutionary activities. ${ }^{137}$

Although the system of national education was unsuccessful, the boycott of government educational institutions gained strength. The government adopted repressive measures to suppress the national movement. ${ }^{138}$ For example, school teachers were required to record the political opinions of students. In other words, teachers were required to act as spies of the colonial government. ${ }^{139}$ Students of the Dhaka College organized a protest against the

\footnotetext{
${ }^{136}$ See Sarkar, Swadeshi Movement in Bengal 1903-1908, 148 -81.

137 Ibid

138 Ibid.

${ }^{139}$ Editorial, Jashohar, Report on Native owned English Newspapers in Bengal, July 16, 1908.
} 
partition. Meetings were held at the Field and Academy Club. But, the protest movements never transformed into a mass boycott of the colonial education system and the movement lost momentum by the end of $1908 .{ }^{140}$ Finally, every attempt was made by the colonial government to suppress the swadeshi movement and ban politics from entering higher education. ${ }^{141}$

Just like the Partition, the Muslim community was also divided over the swadeshi movement. The pro-partitionists started the swa-sampradaya movement, a movement exclusively for and among Muslims. The pamphlet Lal Istahar (Red Letter) suggested that Muslims should boycott Hindus and the nationalist schools established by Hindu intellectuals. Muslim preachers visited Jessore and Pabna and requested Muslim laborers not to serve the anti-partitionist Hindu zamindars. Rezauddin Ahmed believed that if the British had not conquered India then Muslims would have been killed by the Marathas. Islam Darshan opposed the idea of Muslims burning foreign clothes. There was no harm in wearing foreign clothes and Islam did not support such an opposition. ${ }^{142}$ Moreover, the pro-partitionists with the support of maulvis spread separatist messages and this aggravated the communal situation of the province. Communal riots broke out in 1906 in several parts of the province and continued until $1907 .{ }^{143}$

As opposed to the pro-partitionists, the anti-partionists published their opinions in newspapers such as the Bangiya Muslim Sahitya Patrika, Saogat, Banganur, and Moslem Bharat. Anti-partionists campaigned for Hindu-Muslim unity during the swadeshi movement. The Nabanur suggested that Hindus and Muslims of India were brothers and it was impossible to divide them. The native owned Bengali newspapers strongly believed that the policy of Divide

\footnotetext{
${ }^{140}$ See Berwick, "Chatrasamaj: the Social and Political Significance of the Student Community in Bengal 1870 1922," 178-9.

${ }^{141}$ Editorial, The Hitavadi, Report on Native Newspapers in Bengal, August 9, 1913.

${ }^{142}$ Rezauddin Ahmed, "Turkey, England and Russia." Islam Procharak,, Bangali Musalman Sampadito Samoyik Patro, July 1913, 7-8; Editorial," Rejection of Foreign Clothes,"Islam Darshan, Bangali Musalman Sampadito Samoyik Patro .July 1921.

${ }^{143}$ See Sarkar, The Bengali Muslims: A Study in their Politicization 1912-1929, 29-30.
} 
and Rule was used by the colonial government to play one against the other. The newspaper indicated under colonial rule Hindus was the propertied class and the Muslims were peasants. Muslim peasants always opposed the oppressive Hindu zamindar but they failed to understand the imperialist exploitation. The colonial rulers introduced Western education but they excluded political education from the curriculum. The British never wanted any opposition to their rule. Muslims opposed their immediate oppressor but they failed to see the actual motives of the British. The newspaper requested Muslims not to oppose the swadeshi movement. Boycott of goods actually helped India's economy and the swadeshi movement paved the way for India's freedom. Lastly, the Soltan requested Muslims not to act against the swadeshi movement. ${ }^{144}$ The social situation after the partition and the swadeshi worsened with the introduction of separate electorates in 1909. In the Imperial Council, eight out of 27 seats were reserved for Muslims. The electoral qualifications for Muslims were lowered and favored in different government positions. However, the reforms to alleviate the position of Muslims were not extended to the entire community. The Dainik Chandrika and Sanjivani protested against the introduction of separate electorates. The Dainik Chandrika and Sanjivani argued that the idea of separate representation gave an impression that Hindus and Muslims did not have common interests. The colonial government was criticized by both Hindu and Muslim intellectuals for interfering with Hindu- Muslim unity in the province. Newspapers and important individuals expressed a variety of opinions over the swadeshi movement and the introduction of separate electorates. It can be concluded that Muslims were disillusioned by the conservative Hindu approach of the swadeshi movement and separatist messages propagated by maulvis and pro-

\footnotetext{
${ }^{144}$ Maulvi Mohammad Heydayatullah, "Swadeshi Movement," Nabanur, Bangali Musalman Sampadito Samoyik Patro, October, 1905; Editorial, "Rejection of Foreign goods and Muslim Society," Saogat, Bangali Musalman Sampadito Samoyik Patro,March 1930; Humayun Kabir, Muslim Politics 1906 - 1942 (Calcutta: Gupta Rahman \& Gupta, 1944), 10.
} 
partitionists fueled communal sentiments, as Muslims considered Hindus their enemies. At the same time, reforms such as introduction of separate electorates also fueled communal separatism. Immediately after the Partition of Bengal, the situation of Bengal was volatile. At this juncture the colonial reforms and separatist messages acted as a catalyst in increasing the communal divide. $^{145}$

The idea of separate representation for Muslims was extended beyond the Imperial Council, local or municipal boards to educational institutions. The Census of 1901 showed that educational reforms introduced by the colonial government failed to reach the entire Muslim community. For every 1000 males there were only 68 literate Muslim males and for every 1000 females there were only two literate Muslim females. The number of educational institutions slightly improved after the Partition but was not sufficient to influence the entire community. ${ }^{146}$ Along with separate representation, the all India Muslim Educational Conference in 1910 voiced the grievances of the community over restrictions in education. Textbooks used in schools and colleges included stories of Muslim persecution of Hindus. Muslim students were required to appreciate Hindu religious institutions. Muslim literature and religious education was neglected. English education sometimes indicated that Muslims should adopt Christianity. This increased the drop-out rate of Muslim students in primary schools. In case of higher education, a limited number of Muslim students were admitted to the Presidency College. The Calcutta University was usually referred to as a Hindu University and this was mainly because of the absence of Muslims in the University Senate and Syndicate. The university lacked Muslim teachers and so the needs of the Muslim students were not recognized. The Muslim press

\footnotetext{
${ }^{145}$ See Sarkar, Modern India 1885-1947, 140 -2; Editorial, The Sanjivani Report on Native Newspapers in Bengal, July 31, 1913; Editorial, The Dainik Chandrika, Report on Native Newspapers in Bengal, August 11, 1913.

${ }^{146}$ H.H.Riseley and E. A. Gait, Census of India, 1901 (Calcutta: Office of the Superintendent Government Printing, 1903), 157-69.
} 
demanded removal of such text-books, reduction of fees for Muslim students, appointment of Muslim inspectors, a separate budget for Muslim education and inclusion of Muslim students in the Presidency College without any restriction. Unfortunately these reforms did not produce effective results and according to the Census of 1911 only four percent of the entire Muslim community was literate. For the colonial government this was mainly because of the fact that Muslim students spend most of their time memorizing the Koran. So the colonial government came to the conclusion that it was important to establish another university for Muslims in East Bengal. $^{147}$

Abdul Karim, the school inspector argued that with the establishment of colonial rule Muslims were removed from the administration. Persian and Urdu were replaced with English. A large number of Muslim families declined in wealth and status as they lost their jobs. Muslims usually failed to compete with Hindus who were able to make use of the opportunities provided to them by the colonial rulers. He also suggested that movements such as the Suddhi and Mahasabha wanted to convert Muslims to Hinduism and few Hindu leaders promoted unity between the two communities. Hindus held important position in schools, colleges, universities, district boards, municipal boards and there were hardly any Muslims in executive position. In such a situation he demanded reservation of seats for Muslims in the Legislative Council and cooperation with British rule. The Nabanur and Al-Islam suggested that the colonial government proposed to establish a separate university for improving Muslim education. They also indicated

\footnotetext{
${ }^{147}$ See Shah, In Search of an Identity: Bengali Muslims 1880-1940, 30-1, 100-1; Editorial, "Muslim Boarding Houses," Islam Procharak, Bangali Musalman Sampadito Samoyik Patro, February 1902;. Mohammad Fikiruddin Sarkar, "Students Moral Instruction," Basana, Bangali Musalman Sampadito Samoyik Patro, May 1909.
} 
that the proposed university would provide instruction in English, Urdu, Bengali, religion, and politics. ${ }^{148}$

It seemed to the colonial government that establishment of separate institutions was the only method to improve Muslim education. But not just the colonial government, a section of the Muslim middle class felt the same. Al-Islam and Islam-Procharak openly campaigned for such institutions. Muslims were promised a residential university at Dhaka. For the colonial government, Dhaka was the appropriate site for the establishment of the university. The proposed university would include European and Indian professors. Students had to live in hostels for education. The Muslim League in East Bengal welcomed the proposal to establish a separate university in Dhaka. Important members of the Legislative Council including, Honorable Nawab Saiyid Nawab Ali Chaudhuri Khan Bahadur wanted the government to play a greater role in the improvement of Muslim education. He wanted the government to use the imperial grant of seventy five lakh rupees judiciously and appoint Persian and Arabic teachers in high schools which had Muslim students. ${ }^{149}$

However, not all Muslim presses and writers agreed with this approach. The Mussalman opposed the idea of a separate educational institution for Muslims. The proposed university it argued widened the gap between East and West Bengal. Instead they demanded educational grants for Muslims. Muslim intellectuals including Maulana Akram Khan and Abdur Rasul believed that the establishment of another university would increase the financial burden of the colonial government. This would adversely affect the financial assistance received by Muslim

\footnotetext{
${ }^{148}$ Editorial, The Nabanur, Bangali Musalman Sampadito Samoyik Patro, November, 1903; Mohammad Abdul Mullik Khan, "Ekti Nibedan." The Al-Islam, Bangali Musalman Sampadito Samoyik Patro, October, 1919; Abdur Rahim, Presidential Address Delivered at the Session of the All India Muslim League, Held at Aligarh in 1925 (Calcutta: Karim Bux Brothers Printers: 1925), 1-43.

${ }^{149}$ See Sarkar, The Bengali Muslims: A Study in their Politicization 1912-1929, 39-42; WBSA, Government of Bengal, Home Department, Education, Proceedings of the Government of Bengal, November 1914, Proceedings No: 18-23, File No: 1-U/5 2. WBSA, Government of Bengal, Home Department, Education, Proceedings of the Government of Bengal, April 1914, Proceedings No: 11- 14, 34-35, File No: 11-C/41, 11-C/47, 11-C/14, 11-C/40.
} 
primary and secondary education from the government. ${ }^{150}$ Muslim students from various colleges of Calcutta expressed their grievances and demanded an appropriate share of government grants for Muslim education. At this juncture, the colonial government responded to the grievances by promising to establish a separate university for Muslims in East Bengal. Muslims were ambivalent in their responses to the establishment of the Dhaka University. They were unable to decide as whether to accept Western education or live at the mercy of Hindus. In such a situation, faith in the colonial government and the idea of having separate educational institutions appeared to be the best solution to elite Muslims.

The colonial government stressed that the new university at Dhaka would concentrate on culture and education, and would have a less rigid form of examination to increase capabilities of students and a favorable environment for research and originality of thoughts. The colonizers realized that East Bengal was not properly represented in the Syndicate of the Calcutta University as it had only six members. The Islamic Studies Department was the most important feature of the university. It also included departments of Sanskrit, medicine, and law. The government proposed that the university would include the Dhaka College, a women's college, engineering and technical colleges. The inclusion of engineering and a girl's college was essential for the majority of the population to be educated. ${ }^{151}$

After the annulment of Partition of Bengal in 1911, the government used the Dhaka University to pacify Muslims. Along with the proposal to establish a separate university, there were other policies introduced to reorganize and improve madrassahs. The reformed madrassah scheme was expected to improve the lives of Muslim students and make them good Arabic

\footnotetext{
${ }^{150}$ Ibid.

${ }^{151}$ See Sarkar, The Bengali Muslims: A Study in their Politicization 1912-1929, 228; Sarmistha Dutta Gupta, "Saogat and the Reformed Bengali Muslim Women," Indian Journal of Gender Studies 16(2009):329; See Shah, In Search of an Identity: Bengali Muslims 1880-1940, 100-1; WBSA, Government of Bengal, Home Department, Education, Proceedings of the Government of Bengal, Nov 1914, Proceedings No: 18-23 File No: 1-U/5 2.
} 
scholars. This helped Muslims to secure admission in the Islamic Studies Department of the proposed Dhaka University. As a result of this policy, the Chittagong Madrassah was transformed into a Government Muslim High School. The Dhaka Madrassah was also reorganized. The Anglo-Persian department of the Dhaka Madrassah was renamed as the Dhaka Government Muslim High School. However, after the introduction of the reformed madrassah scheme there was decline in Muslim enrollment. The policy did not improve the condition of Muslim education. Muslims lacked sufficient knowledge to adjust to the secular subjects, which were introduced as the madrassahs were transformed into government schools. The enrollment in the Arabic Department of the Chittagong Madrassah decreased from 425 in 1912 to 217 in 1916. Boys were unable to adjust with the reformed madrassah scheme course, failed to meet the demands of the senior madrassah course. Orthodox Muslims were unable to understand the preliminary course structure under this system. Separate maktab education was discontinued under this scheme and the money saved by discontinuing maktab education was invested in scholarships. ${ }^{152}$

Critiquing the reformed madrassah scheme, Muzaffer Ahmed in his work Bangladesher Madrassah Sikha (Madrassah Education in Bengal) argued that in the Chittagong and Dhaka madrassahs, Arabic literature was instructed through the medium of Urdu. Moreover, Urdu was not the language of Bengali Muslims. Only a few students learned proper Arabic in these madrassahs. The translation of Arabic and Persian works to Urdu was a hereditary problem among the Muslims of Bengal. He suggested that madrassahs had to be reformed and Arabic

\footnotetext{
${ }^{152}$ British Library (Hereafter BL), India Office Record and Pvt Papers, (Hereafter IOR) IOR/V/24/4460, Government of Bengal, Education Dept, Quinquennial/ Annual report on the Chittagong Madrassa and the attached institutions, 1912/17 - 1922/23.
} 
had to be taught as the most important course along with Urdu, Hindi, English, Persian, Bengali, Science, and Mathematics. ${ }^{153}$

The colonial education system gave rise to Hindu and Muslim middle classes but the system was unable to fulfill their demands. The Partition of Bengal followed by the national movement and frequent outbreaks of communal riots, only aggravated the political and social situation of the province. However, the Muslim community was not united in their response to the partition, Swadeshi, and the educational reforms introduced after the province was divided. For the Western educated Muslims, partition was a blessing because they didn't have to compete with Hindus. They demanded reservation of scholarships for Muslims and appointment of a specific number of Muslim teachers and inspectors for the province. Eventually they demanded separate educational institutions in the hope that it would Muslim education in the province. The proposal to establish a university at Dhaka and the introduction of the reformed madrassah scheme further strengthened the belief of Muslim community realize that they had separate political objectives and goals. Muslim elite and the middle class demanded that separate hostels were built for Hindus and Muslims. This demand would gradually increase over the next two decades leading to communal tensions. Preferences in the policy formation indeed played a crucial role in increasing the divide between Hindus and Muslims. But for the rural Muslims the post-Partition reforms did not bring about a major change in their social situation. There was no provision for the teaching of Arabic in high schools. Madrassahs were transformed into government schools, which made it difficult for Muslims to adjust to secular subjects. Muslim elites wanted rural masses to just receive religious education, which did not help them to prosper under colonial rule. By the second decade of the twentieth century separatist politics was gaining strength, and Muslims were made to believe that this was the path to progress. However,

\footnotetext{
${ }^{153}$ Muzaffer Ahmed, "Bangadeshe Madrassah Sikha," Bangiya Muslim Sahitya Patrika, November 1919.
} 
collaboration in the beginning and later on resistance against colonial rule did not improve the educational situation of the Muslim community and by World War I it was clear that the establishment of a separate university for Muslims was inevitable.

\section{World War I and the establishment of the Dhaka University in 1921 (1914-1920)}

The war had an enormous influence on the social, economic and political conditions of India. India was drawn into the war as part of the British Empire. This was also the time when the national movement saw a dramatic change. Balgangadhar Tilak and Gandhi raised money for the war in the hope that they would be allowed certain political reforms after the war. During the war, strikes and riots were pretty common in Calcutta. In this social milieu, the upper layer of the bhadralok community worked as doctors, lawyers, and administrators and the rest took up more humble professions under the colonial state or worked in some commercial firms. The urban middle class suffered from price increases, lack of resources, and unemployment. ${ }^{154}$

After the war, the Government of India, for the first time gave Indians the political power that increased the expectation of the colonized population. The Government of Bengal appointed a committee to improve Muslim education. The committee consisted of important Muslim intellectuals including Fazlul Haq, Abdur Rahman Khan Bahadur, Khan Bahadur Maulvi Ahsanullah and also the assistant Director of Public Instruction, Mr. J.A.Taylor. The committee analyzed the reasons for Muslim backwardness and indicated that Muslim decline started with the replacement of Persian with English in 1835. Initially, Muslims were conservative and thought that colonial education would affect their religious beliefs. As a result, they failed to make use of the opportunities provided by the colonial state. But after the Revolt of 1857, Syed

\footnotetext{
${ }^{154}$ See Sarkar, Modern India 1885-1947, 149-51; Pradip Sinha, Calcutta and the Currents of History 1690 -1912, ed. Sukanto Chaudhuri (Calcutta: Oxford University Press, 1990), 40-1. Balgangadhar Tilak: A nationalist leader, who turned to Marathi, as a medium to gain mass support. He edited the Marathi language newspaper Kesari, ("The Lion") to reach the lower middle class population of South India. See Wolpert, A New History of India, 262-3.
} 
Ahmed and Nawab Bahadur Abdul Latif played an important role in changing Muslim approach towards Western education. Muslim intellectuals emphasized the need to study English. The knowledge of English helped Muslims to secure jobs under colonial rule. As a result, over time there was a considerable demand for English medium schools among Muslims. ${ }^{155}$

The committee made certain suggestions to improve Muslim education. First, it was necessary to appoint Muslims on district boards and governing bodies of educational institutions. Second, seats had to be reserved for Muslims in different schools of the province. Third, Muslim authors needed to publish textbooks, and higher salaries had to be offered to Muslim graduates. This would encourage them to take up teaching jobs in government schools. It was necessary to appoint Muslims as Assistant and Additional Inspectors of schools. Fourth, the managing committee of every school had to include two Muslim officers in order to receive grants from the colonial government. Fifth, Arabic and Persian teachers had to be appointed in schools, which had Muslim students. Sixth, the colonial government had to subsidize English medium high schools in order to include Muslim students. Finally, special scholarships had to be introduced for Muslim students. ${ }^{156}$

The committee also demanded greater representation for Muslims on the district boards and governing bodies of educational institutions. The absence of Muslim teachers directly affected the admission of Muslim students. For example, in Jessore, Khulna (districts in East Bengal), Birbhum, and Bankura (districts in West Bengal) Muslims held just three to four teaching positions, whereas Hindus held somewhere between 16 to 50. The committee recommended that religious instruction had to be provided by a Muslim cleric attached to a local mosque. Every Friday all primary schools had to be suspended for one hour for midday prayers.

\footnotetext{
${ }^{155}$ India. The Governor General in Council Bengal, Report of the Bengal Committee on Muhammadan Education, (Calcutta: GPO, 1914), 1-55.

${ }^{156}$ Ibid.
} 
Educational institutions had to be established in bigger cities so that students from neighboring villages could attend these schools. However, the committee opposed the idea of having separate schools for Muslims. This would increase the financial burden on the government, which would have an adverse impact on Muslim education. The committee wanted an overall improvement of Muslim education. ${ }^{157}$

The committee wanted both English and religious education for Muslims. The demand for both types of education remained constant throughout the first and second decades of the twentieth century. However, the proposals for separate education were opposed as the committee thought that it might lead to communal tension. This was a shift from the proposals of Latif, who demanded separate schools for Muslims. We notice a difference of opinion within the Muslim community. A section of the Muslim intellectuals feared that separate institutions world further solidify the differences between Hindus and Muslims. But intellectuals such as Latif preferred that separate institutions would help Muslims to progress under colonial rule. The popularity of English forced Muslims to rethink about their approach towards Western education. At the same time, a section of the Muslim population feared that separate electorates and educational institutions were increasing the division in the colonial society. The fear was justified as there was an intense tension between the two communities during the 1930s and 1940s. In an attempt to adjust to the colonial policies, a section of the Muslim community felt that separate educational institutions were a solution to their educational problems.

Based on the committee's recommendations, important Muslim teachers, including Maulvi Tasadduk Ahmad, Maulvi Mowla Baksh, and Maulvi Kazi Imadul Haque, were nominated for the post of Assistant Inspector of Schools for Muslim education in each of the five

${ }^{157}$ Ibid. The Mussalman, Report on Indian owned English Newspapers in Bengal September 10, 1915; Editorial, The Amrita Bazar Patrika, Report on Indian owned English Newspapers in Bengal, September 11, 1915. 
divisions of the Presidency. Recommendations from Muslim teachers increased government grants to several secondary schools including the Narail Victoria High English School in West Bengal, Pangsya Middle English School in Dhaka, and the Pabna Middle Vernacular School for Girls. Despite these recommendations, Muslim students were not admitted to the Calcutta Medical College. Similarly, Brojomohan College in East Bengal admitted 250 Hindu students and only 50 Muslim students. The committee's recommendations to a certain extent improved the status of Muslim education but it still did not impact the entire community. Discrimination in education existed as the reforms were not extended to the entire community. Only elite Muslims benefited from the reforms and the government supported their idea of a separate Muslim university. ${ }^{158}$

The colonial government appointed the Calcutta University Commission in 1917 under the chairmanship of Michael Sadler, the British educationist. The commission indicated that proper university education would improve secondary education. They recommended the formation of boards consisting of representatives of government, high schools, universities, and intermediate colleges. The commission proposed to free Indian universities from government control. In the case of Muslim education, Michael Sadler wanted Muslims to follow the Islamic tradition and culture. He supported the reconstruction of Muslim education in accordance with the social, political, and religious atmosphere of the country, and the commission strongly recommended the establishment of a separate residential university at Dhaka. Apart from establishment of a

\footnotetext{
${ }^{158}$ WBSA, Government of Bengal, Home Department, Education, Proceedings of the Government of Bengal, April 1914, Proceedings No: 41 File No: 3-I/12; WBSA, Government of Bengal, Home Department, Education, Proceedings of the Government of Bengal, April 1914, Proceedings No: 1-2, File No: 7-E/1 1; WBSA, Government of Bengal, Home Department, Education, Proceedings of the Government of Bengal, April 1914, Proceedings No: 67-68, File No: 11-C/32; WBSA, Government of Bengal, Home Department, Education, Proceedings of the Government of Bengal, February 1915, Proceedings No: 77-78, File No: 4-C/9 1; Editorial, The Sanjivani, Report on Indian owned English Newspapers in Bengal, July 8, 1915; Editorial, The Mohammadi, Report on Indian owned English Newspapers in Bengal, August 8, 1915; M.M. Ahmad, Present Day Problems of Indian Education: With Special Reference to Muslim Education (Bombay: B.N.Kapadia at the Fine Art Press, 1935), 43.
} 
separate university, the government proposed to demolish the Calcutta Madrassah and establish a Muhamadan College at Dhaka. They also wanted to establish an Arts College for Muslims in Calcutta. But the Government of Bengal could not financially support any of the proposals but they firmly believed that separate educational institution were the only method to improve Muslim education. ${ }^{159}$

Throughout the second half of the nineteenth century and early twentieth century, we see different voices within the Muslim community. Muslim elites and the middle class believed that religious education at the primary level was very important. It helped Muslims to maintain their religious identity. The colonial government also encouraged religious instruction as this helped to secure the support of Muslims. Muslim intellectuals also prescribed religious education for rural masses as it reduced the competition for jobs. A constant conflict existed within the Muslim community over the demand for separate educational institutions. However, this emphasis on religious instruction strengthened separate identities both in urban and rural areas as Muslims were constantly reminded of their different goals and objectives under colonial rule. Later in the dissertation we will notice there was huge demand to consider maktabs as primary schools instead of just religious institutions.

The Indian Association opposed the idea to establish a separate university at Dhaka because they believed that it would destroy the educational life of the province. The AngloIndian Press also condemned the proposal. The press claimed that the colonial government proposed to establish the Dhaka University to please the people of East Bengal. They didn't have enough money to support the Calcutta University and in such a situation it would be a financial

\footnotetext{
${ }^{159}$ Suresh Chandra Ghosh, The History of Education in Modern India 1757-2007 (Delhi: Orient Blackswan Private Limited, 1995), 145-7; See Shah, In Search of an Identity: Bengali Muslims 1880-1940, 102; National Archives of India (Hereafter NAI), Government of Bengal, Education Department, Proposed Establishment of an Arts College for Muhammadans in Calcutta and the Reorganization of the Calcutta Madrassa and Its attached Institutions, October 1915, Proceedings No: 88-89, Part A.
} 
disaster to establish another university at Dhaka. ${ }^{160}$ But the opposition was not strong enough to deter the colonial government from its decision. By supporting the proposal for the Dhaka University, the colonial government encouraged education but reinforced separatism. ${ }^{161}$

Although the anti-loyalists opposed the decision, the government in 1915 strongly supported the idea to establish a separate university for the Muslims.

Despite the committee's recommendations, the report of the Director of Public Instruction showed that the number of educational institutions both public and private increased from 50,887 to 51,701. The expenditure on education increased from rupees 3968,560 to rupees 40 24,826. 50.6 percent of the funds came from private sources and 49.4 percent of the funds came from the government. Private funding was essential to improve education. Unfortunately, the number of students decreased from 1965,273 to 1931,535. The total number of Muslim students in all forms of educational institutions declined from 899,679 in 1917-1918 to 891,118 in 19181919. The number of students in arts colleges remained the same. The number slightly increased in case of professional schools but it was still far from any major improvement. In high schools it declined from 20.2 percent in $1917-1918$ to 20.1 percent. The only increase was noticed in primary schools. The report indicated that Muslims did not advance beyond the primary level. In the case of madrassah education, the number of students increased and the Government of Bengal proposed to introduce Islamic intermediate classes at the Dhaka Madrassah. But most of the madrassahs were maintained by private funds. ${ }^{162}$

\footnotetext{
${ }^{160}$ The Proposal for a University at Dacca, February 5, 1912, India Office Record and Pvt Papers, British Library, Ref : IOR/V/L/PJ/6/1140; Editorial,The Dainik Basumati, Report on Indian owned English Newspapers in Bengal, September 2, 1915.

${ }^{161}$ See Shah, In Search of an Identity: Bengali Muslims 1880-1940, 102-3.

${ }^{162}$ WBSA, Government of Bengal, Education Department, Proceedings of the Government of Bengal, August 1920 , Proceedings No: 73, File No: 8-R-1(1).
} 
According to the government, enrollment declined due to crop failure, spread of diseases, and adverse economic conditions. But many schools and colleges were reluctant to include Muslims. Most schools did not have provision for instruction in Arabic and Persian, which was essential for Muslim students. Fazlul Huq suggested that Muslim education would not improve unless provision was made for the teaching of Arabic and Persian. ${ }^{163}$ Apart from these conditions, the colonial government also did not have enough money to support separate educational institutions. The government wanted private associations and wealthy individuals to start the educational institutions. The Primary Education Bill was introduced in the Legislative Assembly in 1919 was not implemented until 1930 as the colonial government didn't have enough funds to support free compulsory primary education. ${ }^{164}$ By the twentieth century the entire education system in Bengal was suffering from financial crisis and the decision to establish separate institutions only increased the burden for the government.

Despite intense opposition and financial crisis after the war, the colonial government passed the Dhaka University Act in 1920. The Act reorganized high schools and intermediate colleges in Dhaka and created the Provincial Intermediate and Secondary Education Board. The Dhaka University provided instruction in English, Bengali, Mathematics, Geography, Physics, and other classical languages. The Jagannath Intermediate College was included in the Dhaka University. The act also established the Muhammadan Intermediate College and Salimullah College at Dhaka. The Salimullah College specialized in Persian, Arabic and Urdu but it also included Hindu students as the Dhaka University Committee opposed complete segregation. However two-thirds of the seats were reserved for Muslim students. The act proposed the

\footnotetext{
${ }^{163}$ Ibid; WBSA, Education Department, Government of Bengal, Proceedings of the Government of Bengal December 1920, Proceedings No: 89-91, File No: 11-C-66.

${ }^{164}$ WBSA, Government of Bengal, Education Department, Proceedings of the Government of Bengal, Proceedings, August 1920, Proceedings No: 73, File No: 8-R-1(1); See Shah, In Search of an Identity: Bengali Muslims 18801940, 102-3.
} 
establishment of another intermediate college called the Gandaria College which had 33 percent seats reserved for Muslims. Along with these two colleges, the Muhammadan Intermediate College or the Islamic Intermediate College included the senior department of the Dhaka Madrassah, which provided instruction in Urdu, Persian, and Arabic. ${ }^{165}$

The Dhaka University Act established not just a separate university but also colleges, which included Hindu students. The education policy up to 1920 introduced mostly a system of reservation in educational institutions. Muslims were given preference in most of the colleges of East Bengal and later on a Muslim Hall was built for Muslim students studying at the Dhaka University. By the turn of the century Muslims realized English education was necessary for progress. However, the colonial government pacified Muslims by popularizing both religious and English education. This in turn strengthened separate religious objectives and identities and remained a constant problem over the next few years. The colonial government projected that religious education helped Muslims to survive the national movement and this could only be achieved in separate institutions. In other words, colonial education policies strengthened communal feelings.

\section{Conclusion}

By the first two decades of the twentieth century there was both continuity and shift in colonial education policies. First, private initiative in education increased, wealthy Indians, private organizations, and anjumans established schools in districts and villages, which to a certain extent received support from the colonial state. The public-private partnership in education was mostly moving towards private control of education. The state wanted Bengali elites to take charge of mass education. Second, English became the most important language

\footnotetext{
${ }^{165}$ NAI, Government of Bengal, Education Department, The Constitution of the Dhaka University, April 1920, Proceedings No: 79-87, Part A.
} 
under colonial rule. The colonial government wanted to use vernacular for primary schools and English for high schools. This was having a drastic effect on students from rural locations as they found it difficult to adjust to a foreign language in higher classes. This was a shift from the recommendations of the Wood's Despatch. The despatch recommended vernacular education for the masses and English for the elites. However, the demand for English was far greater than any vernacular languages. The government mostly supported schools, which provided English education. The popularity of English marginalized vernacular languages. In the case of Muslims religious education was more popular than English. However, Muslims started learning English in order to secure employment. But, there was no government support for just religious education despite the fact that there was a huge demand for it from the Muslim community.

Elite Muslims felt that separate educational institutions protected them from Hindus. The government also responded to their demands. But the rising Muslim middle class was divided in their approach towards Western education. Some believed that such policies divided the country along communal lines. Mostly students opposed separate schools but for the loyalists cooperation with the colonial government was the only method to improve their social status. The elites also had the support of the rural masses. Elite Muslims used anjumans and mullahs to secure support for separate schools and electorates. The grievances against Hindu landlords also helped to solidify communal feelings. The support for separate educational institutions was the first step that helped Muslims become aware of their separate goals as a community. Historians have argued that separate electorates and institutions to a certain extent satisfied the demands of the Muslim middle class. However, the results showed that these separate institutions also suffered from financial crisis and mostly depended on private resources. A constant tension existed in the society over separate educational institutions and the division within the 
community further deepened in the twentieth century with the partition and the swadeshi movement. ${ }^{166}$

After the Partition, swadeshi movement, and the First World War, unemployment and price rises forced the middle class to turn against colonial rule. The middle class to some extent were influenced by socialist ideology and felt it was necessary to counter the imperial rule. ${ }^{167}$ The colonial government responded to the demands of the middle class by reorganizing colonial education and establishing a separate university for the Muslims. The government believed that separate educational institutions helped to improve Muslim education. This approach also allowed the British to sustain their rule in India. However, these separate institutions suffered from financial crisis. For example, the next chapter will show how the Dhaka University, which was predominantly established for providing education to the Muslims of East Bengal, suffered from financial crisis immediately after its establishment. The absence of stable financial support only complicated matters, as Muslims constantly demanded greater representation on the managing committees of educational institutions and reservation of scholarships and seats in these institutions. Separate schools, textbooks, and education strengthened their belief that as a community they were different from the Hindus and needed special privileges over them. The complexities over education policies were fueling religious tensions, which aggravated the communal situation of the province. This chapter shows that politicization of education policies solidified communal differences between Hindu and Muslim middle classes

\footnotetext{
${ }^{166}$ See Ahmed, The Bengal Muslims 1871-1906: A Quest for Identity, 161-3.

${ }^{167}$ See Sarkar, A Critique of Colonial India, 69.
} 


\section{Chapter 5}

\section{Muslim education during the period of political turmoil, 1921-1935}

\section{Introduction}

After the Partition of Bengal (1905) and the Morley Minto reforms (1909), the British in India expanded imperial and legislative councils considerably to include more Muslim landlords and professionals. Moreover, the qualifications for Muslim voters were lowered and separate electorates were established in several provinces. Despite several concessions offered by the colonial state, the financial crisis of the 1920s and 1930s had an adverse influence on the progress of Muslim education. Along with the financial crisis, historians have argued that education policies were constantly influenced by the political events of the period, which motivated the British to introduce separate electorates and educational institutions for Muslims. The policy of communal separatism introduced by the British made the Muslim community believe that separate educational institutions were necessary for the advancement and progress of the community. ${ }^{168}$

This chapter examines the state of Muslim education in colonial Bengal in the 1920s and 1930s. It explores the impact of legislative acts on education. For example, the MontaguChelmsford reforms of 1918 further supported the idea of separate educational institutions and electorates for Muslims. The demand for separate educational institutions for Muslims resulted in the establishment of the Dhaka University in 1921. Dhaka University is used here as a case study to measure the progress made by the Muslims of East Bengal after the introduction of diarchy (explained later) in 1918. At the same time, legislative and educational reforms

\footnotetext{
${ }^{168}$ Peter Hardy, The Muslims of British India (Cambridge: Cambridge University Press, 1972), 168-97. See Sarkar, Modern India 1885-1947, 140-1.
} 
intensified the demand for Muslim representation in school committees, university senates, and municipalities. Muslim members of the Bengal Legislative Council demanded special provision in the budget for their community and the reservation of seats for Muslims in educational institutions and government jobs. ${ }^{169}$ The reforms introduced by the colonial state wanted to include more Muslims in the development of the country but it did not guarantee them employment as there were limited jobs during colonial rule.

This chapter also analyzes the impact of historical events such as the Khilafat (1919), Non-cooperation (1919-1922), and Civil Disobedience movements (1930-1932) on colonial education policies. During the interwar years, the number of Muslim students in professional and arts colleges decreased. Reservation of seats did not improve the educational situation of the community, and Muslims considered Hindus to be their competitors and enemies. The role played by Muslim leaders in the implementation of the Bengal Rural Primary Education Bill of 1930 is also reviewed in this context.

I argue that the effort to introduce responsible government in Bengal only intensified the separatist ideology. Nation-building institutions, such as the education system, did not adequately improve the social status of the Muslims. The Bengal Education Department struggled throughout the colonial period to develop policies that would help the masses. Limited resources, discrimination in education and employment followed by the failure to implement policies turned the Bengali intelligentsia against colonial rule. This failure convinced Muslims to believe that only separate educational institutions would improve their social status and strengthened the idea that only Muslim aspirations were different from those of Hindus. In other

\footnotetext{
${ }^{169}$ See Sarkar, The Bengali Muslims: A Study in their Politicization 1912-1929, 145-6.
} 
words, educational reforms escalated Muslim separatism during the 1920s and 1930s, which prepared the ground for the emergence of separate nations in 1947.

\section{The last stage of Hindu Muslim Unity: from World War I to the Bengal Pact of 1923}

(1916-1923)

\section{A) Impact of the Montagu-Chelmsford reforms on the progress of Muslim education.}

This section explores the status of Muslim education after World War I. After the war, there was definite shift in British Indian policy. In order to pacify the Indians, the colonial government allowed Indians to participate in the development of the country. The MontaguChelmsford reforms started the system of diarchy, where elected ministers of the provincial legislatures independently looked after departments such as agriculture, education, and health. This section shows that although Indians were allowed to participate in the decision making process, major education policies were formulated and controlled by the government.

During World War I, the Indian revolutionaries organized several conspiracies to overthrow the colonial government. The government responded to such conspiracies by introducing the Defense Act of 1915, which detained suspects without trials. However, leaders such as Mahatma Gandhi and Balgangadhar Tilak supported the British during World War I. They hoped that the colonial rulers would introduce major political reforms in return for such loyalty. This loyalty to a certain extent produced effective results, as the colonial government introduced self-governing institutions in 1915. The government wanted Indians to participate in the process of developing the country. This shift in the British policy influenced the progress of education. The Bengal Government introduced the reformed madrassah system in 1915 to improve Muslim education. The two important features of the scheme were: introduction of 
English as a compulsory subject and the exclusion of Persian from the curriculum. The syllabus for maktab courses was also revised. However the Calcutta Madrassah adhered to the old course structure but other madrassahs had to adopt the revised curriculum. ${ }^{170}$

Muslim intellectuals, such as Munshi Imdad Ali and Khan Bahadur Ahsanullah, supported the colonial policy of reforming madrassahs. They believed that madrassahs should introduce English, as this helped Muslims to progress. Also, just a few Muslim students wanted to pursue the orthodox course of education. Even maulvis from northern India such as Jame-ululoom suggested that the reformed madrassah system improved the social condition of the community. The reformed madrassah system established madrassahs in rural areas and introduced a secular curriculum that helped Muslims to secure government jobs. ${ }^{171}$

Although changes were introduced to reform the madrassahs, the Bengal Government passed a resolution on November 16,1915, which changed the policy of the distribution of the Mohsin Fund. The Bengal Government decided that provincial revenue would bear the expenses of all the government and non-government madrassahs of the province. This was a shift from 1871 policy where the Mohsin Fun was used to maintain the madrassahs. The government decided to give small stipends to poor Muslim students from the Mohsin Endowment Fund. Posts of five assistant inspectors for Muslim education were abolished, and grants for maktabs and madrassahs were decreased by 7,500 and 220,000 rupees respectively. The number of Muslim students declined at the Dhaka Madrassah between 1918 and 1921 from 425 to 315. Similarly, at the Chittagong Madrassah, the number declined from 190 to 164. Lack of government assistance, absence of Muslim teachers, and poverty affected the enrollment of

\footnotetext{
${ }^{170}$ See Sarkar, Modern India 1885-1947, 149-68.

${ }^{171}$ West Bengal State Archives (Hereafter WBSA) Government of Bengal, Education Department, Proceedings of the Government of Bengal, February1915, Proceedings No: 122, File No: 1-M/6 -1.
} 
Muslim students in middle and high schools. Muslim students in middle schools decreased from 24,857 in 1916 to 15,401 in 1922. A similar situation was noticed in high schools in Bengal, where the number of Muslim students decreased from 19,916 in 1916 to 14,168 in $1922 .{ }^{172}$

Government records indicate that adverse economic conditions forced the government to reduce financial support to schools. However, this decrease in financial aid was condemned by educationists such as M. Azizul Huque. According to Huque, Muslims were forced to discontinue their education and schools, colleges, and universities preferred Hindus over Muslims. In 1917, Calcutta had 1,700 Muslim undergraduates, of which only 125 students were able to study at the elite Presidency College. The rest were mostly admitted to City, Ripon or Bangabashi colleges. In these colleges, Muslim students were unable to pursue education in Persian, Arabic or History. Out of the 800 students admitted in medical colleges, only ten were Muslims. Shibpur Engineering College had no Muslim students. In most cases they were unable to pay the high fees of the Shibpur Engineering College. Muslims were also afraid to study engineering because they were not sure whether they would secure employment after the war. A few charitable funds helped Muslim students to pursue higher education. The Calcutta University did not elect Muslims as fellows of the university. Hindus only had the right to vote, and qualified Muslims were not included in the syndicate of the Calcutta University. M. Azizul Huque in his work History and Problems of Muslim Education in Bengal, criticized Calcutta University for not providing equal opportunities to students from different religions. Muslims in Bengal were denied government jobs because there were only a few Muslim representatives in

\footnotetext{
${ }^{172}$ WBSA, Government of Bengal, Education Department, Report of the Committee to advise on the policy advancing Muslim education in Bengal, March 1935, Proceedings No:1, File No: 8-R-24 (1) of 1934; British Library (Hereafter BL), Government of Bengal, Various reports on the Dhaka University, 1922-26, MSS/EUR E221/5; BL, Government of Bengal, Newspaper cuttings about the Dhaka University, August 1921, MSS/ EUR 221/4; BL, Government of Bengal, Annual Report on the Chittagong Madrassa and attached institutions, 1912 /17 1922/23, IOR V/24/4460; See Huque, History and Problems of Moslem Education in Bengal, 96-100.
} 
the administration or on the managing boards of educational institutions. Moreover, Huque was skeptical of Lord Hardinge's proposal to establish a new university for Muslims at Dhaka, as he felt that this would only complicate the political environment of the province (refer to the footnote). ${ }^{173}$

However, Huque also recognized the limitations of the government and urged the Muslim community to solve their own problems instead of depending on the government. He wanted Muslims to change their attitudes towards education in order to progress and compete with Hindus. Huque did not have much faith in the government, but advised Muslims to look beyond their religious goals of being a good Muslim and make use of the limited opportunities offered by the colonial government. He believed that the community should progress organically instead of depending on the government. ${ }^{174}$

Following the above recommendations of Huque, Muslims were eager to learn English. For example, maulvis from North India, such as Maulvi Abu Muhammad Abdul Huq of Delhi, suggested that English had to be introduced as a compulsory subject in the madrassahs and that Islam did not oppose the study of other languages. However, the Mohsin Fund, which was previously used to manage the madrassahs was only used for providing stipends to poor Muslim students. The actual functioning of the madrassahs depended on provincial revenues, which was never a stable source of support. Similarly, colleges also suffered from financial problems. For example, during the war, the government withdrew support from Brojo Mohan College of East Bengal, as they were dissatisfied with the discipline of the college. This decrease in financial

\footnotetext{
${ }^{173}$ See Huque, History and Problems of Moslem Education in Bengal, 111-34. After the annulment of the Partition in 1911, Lord Hardinge proposed to establish the Dhaka University, as a method to calm the troubled feelings of the Muslims of East Bengal. Huque believed that a separate university only aggravated the communal situation. Muslims required an education policy that suited their needs. The general education system mostly supported the needs of the Hindus. It did not fulfill the actual needs of the Muslim community.

${ }^{174}$ Ibid., 138-44.
} 
assistance affected the progress of education among Muslims of East Bengal. Although Muslims were interested in English education, the absence of a stable educational infrastructure prevented the advancement of the community in the twentieth century. ${ }^{175}$

Towards the end of World War I, the Montagu-Chelmsford reforms of 1918, the Government of India Act of 1919, and the political movements that were led by Gandhi (discussed in the next section) shaped the future of the Indian national movement in the twentieth century. The Montagu-Chelmsford reforms took the final shape under the Government of India Act of 1919. The act of 1919 transformed the Central Legislative Council into a bicameral parliament consisting of the Imperial Legislative Council and the Council of State. The Imperial Legislative Assembly consisted of 140 members of which 100 were elected. The council of states had 60 members of which 40 were elected. The act gave five million landowning taxpaying educated Indians the right to elect their representatives in provincial councils. One million could vote for the assembly and 17,000 for the council of state. The viceroy's Executive Council had at least three Indians and the provinces had several Indian ministers to preside over transferred departments such as agriculture, education, public health and public works. At the same time, vital departments such as finance and revenue were controlled by the government. For example in the case of revenue, land revenue was collected by the provincial government and the income tax by the Government of India. The act not only retained but also extended separate electorates, communal representation, and reservations. ${ }^{176}$

\footnotetext{
${ }^{175}$ WBSA, Government of Bengal, Education Department, Proceedings of the Government of Bengal, February1915, Proceedings No: 134-135, File No: 1-M/6 -12; WBSA, Government of Bengal, Education Department, Proceedings of the Government of Bengal, September 1914, Proceedings No: 77-78, File No: 4-C/9 1. ${ }^{176}$ Sumit Sarkar, Modern India 1885-1947, 149-68. After the war, Lord Crewe, the secretary of state, rejected the idea of Indian self-government. However, Chelmsford considered Indian public opinion on various issues such as export of coolies through the indentured labor system, recruitment of Indians in the army, and framing of education policies. Historians have argued that the Morley-Minto reforms created a powerful Indian opposition in the councils
} 
However, the reforms proposed by the Government of India Act of 1919 were not free from criticisms. Abdul Karim, an honorary fellow of the Calcutta University, at the annual session of the Bengal Provincial Muslim League in 1920, suggested that the reforms did not improve the overall condition of Muslims. He felt the system of separate electorates and schools were unsuitable for the community. There was a dearth of qualified Muslims who could represent the community in local councils and also on the managing committees of middle and high schools. Muslim schools did not have Muslim teachers, and textbooks were unsuitable for Muslim students. Inadequate scholarships, high fees, absence of high schools in Muslim localities, and the non-cooperation movement hindered the advancement of the community. Karim wanted to extend mass education and desired the establishment of another teaching university. Although the Education Department was transferred to the elected ministers, the concern remained the same over the next few years. There was a huge demand for financial assistance from the government. ${ }^{177}$

Both Huque and Karim worked for the colonial government, yet they vehemently opposed the proposal to establish a separate university for Muslims at Dhaka. According to them, the proposed university would increase the financial burden of the government because it involved duplication of efforts. However, despite all the criticisms, the Dhaka University was established in 1921. It was established to provide instruction in Islamic Studies to the Muslims

instead of collaborators. Influential British intellectuals such as Philip Kerr, Lionel Curtis, and William Duke, realized that it was a disastrous idea to give the elected non-officials more power without any executive responsibility. Hence, they came forward with the idea of diarchy in the provinces.

Mushirul Hasan, "Communalism in the Provinces: A Case Study of Bengal and the Punjab 1922-1926," in Communal and Pan-Islamic Trends in Colonial India, ed. Mushirul Hasan (New Delhi: Manohar Publications, 1981), 248-60. See Wolpert, A New History of India, 322.

${ }^{177}$ BL, Government of Bengal, Presidential Address delivered at the Annual session of the Bengal Presidency Muslim League, 1920, IOR/General Reference Collection-8023; WBSA. Government of Bengal, Education, Report of the Committee to advise on the policy advancing Muslim education in Bengal, March 1935, Proceedings No:1 File No: 8-R-24 (1) of 1934; See Sarkar, Modern India 1885-1947, 164-8. 
of East Bengal. It also provided instruction in Bengali, Classical languages, English, Geography, Mathematics, and Physics. The university included the Dhaka, Jagannath Intermediate, Muhammadan, and Salimullah colleges, along with a college for women and a technical institute. The colonial rulers wanted to build a residential university at Dhaka, which encouraged research and originality of thoughts. Unlike the Calcutta University, which included students from several colleges, the students of the Dhaka University were required to reside in halls or hostels following a strict code of discipline prescribed by the university. Students of either sex were admitted without any discrimination on the basis of race, creed, or class. The university also granted degrees and awarded fellowships. Religious instruction was an important part of the curriculum. Students were admitted after passing the intermediate examination, and the university offered instruction in arts and sciences. Sir Philip Hartog, the first vice-chancellor of the Dhaka University, wanted to include more Muslim students in order to improve the educational status of the community. He requested the elected ministers for more grants. ${ }^{178}$

The annual reports of the Dhaka University from 1922 to 1924 showed that students were keen on attending the new university, which provided new methods of intellectual training and unparalleled facilities for athletics. There were suggestions to improve the library and also appoint a full-time professor for the Arabic and Islamic Studies Department. The number of students at the university increased between 1922 and 1923 from 1,105 to 1,330. Similarly, the number of medical and research students increased from 121 to 139 and from ten to 19 between 1923 and 1924. The Dhaka University officials notified that there was a decrease in the number of students studying humanities, whereas there was an increase in the number of students

\footnotetext{
${ }^{178}$ National Archives of India (NAI), Government of Bengal, The constitution of the Dhaka University, April 1920, Proceedings No: 79-87, Part A; WBSA, Government of Bengal, Education, Proceedings of the Government of Bengal, November 1914, File No: 1-U/5 2; BL, Collection of Sir Philip Hartog: Dacca University Journals 1925, MSS EUR E221/142; BL, Collection of Sir Philip Hartog: Dacca University Publications, calendars and annual reports 1922-23, MSS EUR E221/62.
} 
pursuing science and law. The university provided several opportunities for publication of research. Students had to reside in halls, and there was a separate hall for Muslim students. The Muslim Hall offered Quranic classes, and the halls played a significant role in the overall development of students. They were required to participate in debates, sports, and social service. For example, the Jagannath Hall of the Dhaka University required students to attend all the lectures and they were not allowed to miss more than three classes. Each hall had a social service league, which provided the poor villagers with education during the term. The government was confident that this residential form of education would benefit students. ${ }^{179}$

However, the colonial government reduced financial aid to the Dhaka University immediately after its establishment in 1922. The Bengal Retrenchment Committee, established in 1921 to monitor the savings of the colonial government in the province, decided to reduce the financial aid in order to maintain a strict budget. The Dhaka Herald and A Voice from East Bengal in 1922 criticized the government and the retrenchment committee for reducing a grant of five lakh rupees to one lakh without proper inspection of the university. The progress of applied sciences and technical courses was affected by this reduction in financial assistance. The expenditure on books and libraries decreased, and professors were not appointed to the Arabic and Islamic Studies Department. The university had no other source of funding except for government assistance and the retrenchment committee suggested that students' fees had to be increased. Abdul Karim had already predicted this situation in 1920. The residential university was unaffordable for a vast majority of poor Muslims, and the decrease in grant money affected

\footnotetext{
${ }^{179}$ BL, Government of Bengal, University of Dacca, Annual Report for 1922-23, MSS EUR E221/65; BL, Government of Bengal, Rules for students of the Jagannath Hall, Dacca University, 1928, MSS EUR E221/120; WBSA, Government of Bengal, Education Department, Proceedings of the Government of Bengal, December 1925, Proceedings No: 81- 95, File No: I-U-92 (1) of 1924.
} 
the progress of education. A section of the Muslim population was educated, as they were the only ones who could pay the increased fees of the Dhaka University. ${ }^{180}$

Newspaper reports also indicated that the Dhaka University did not improve the educational condition of Muslims. There was mass illiteracy and this aggravated the political situation of the province, as Muslims blamed the colonial government and powerful Hindus for their impoverishment. The colonial government did not appoint Muslim officers to different posts within the Dhaka University. For example, in the Economics Department, a Hindu and a Muslim candidate with the same qualifications were interviewed, and the Hindu candidate was appointed to the post. This was due to the fact that the Hindu candidate had six months work experience, whereas the Muslim candidate had five months work experience. Despite several recommendations that the Muslim candidate be appointed, the committee selected the Hindu candidate. Even the vice-chancellor of the university was unable to change the unanimous decision of the committee. A similar incident took place in the law department where a qualified Muslim lawyer was not appointed as the chair of the department. There were not just financial crises but also discrimination in the appointment of Muslims as officers and teachers. The power of nominating Muslims as university fellows was never properly exercised by the colonial government. The government in practice preferred Hindus over Muslims and hence the reforms introduced failed to generate the desired results. Gradually, these grievances increased over the next two decades leading to communal tension and eventually riots. ${ }^{181}$

The number of educated Muslims increased from the nineteenth to the twentieth century, but the impact was never felt by the entire community. Even after the establishment of the Dhaka

\footnotetext{
${ }^{180}$ BL, Government of Bengal, Various reports on the Dhaka University, 1922-26, MSS EURE221/5; BL, Government of Bengal, Newspaper cuttings about the Dhaka University, August 1921, MSS EUR221/4.

${ }^{181}$ WBSA, Government of Bengal, Education, Report of the Committee to advise on the policy advancing Muslim education in Bengal, March 1935, Proceedings No: 1, File No: 8-R-24 (1) of 1934.
} 
University, where preference was given to Muslims, Hindus dominated academia and the administration of the university. The colonial government favored Hindus over Muslims for various positions. This to a great extent also contributed to the discrimination. Hindu committee members were mostly selecting educated members from their community. Qualified Muslims did not have jobs and students from poor Muslim families were unable to study at Dhaka University. Azizul Huque had previously indicated that the education system suited the needs of the Hindus. The attention to Muslim education was merel a by-product of the general education system. This approach towards Muslim education continued even after the establishment of separate educational institutions. A vast section of the Muslim population was deprived of the benefits of education. Finally, this approach strained the relationship between Hindus and Muslims. ${ }^{182}$

Although some elite Muslims, after the partition of Bengal, demanded separate educational institutions in 1905, they failed to realize that separate schools did not receive sufficient financial aid from the government. The colonial government constantly decreased financial assistance, which increased competition in the field of education and employment. A few colonial officers, such as Sir Philip Hartog, wanted the government to help Muslims by increasing fellowships, but they recognized that it increased the financial burden on the government. Limited opportunities and lack of financial assistance from the government increased the animosity between the two communities. Bengali newspapers, such as the Soltan, and Hanifi, in the second half of the 1920s, blamed the colonial government for creating this rift between Hindus and Muslims. The absence of opportunities forced Muslims to demand reservation in government jobs, educational institutions, and legislative councils. Hindus opposed the system of reservation but Muslims supported it. This conflict aggravated the

\footnotetext{
${ }^{182}$ See Huque, History and Problems of Moslem Education in Bengal, 95.
} 
communal situation of the province. Although the Khilafat and the non-cooperation movements united the two communities briefly, they were unable to provide a long term solution to the problem. $^{183}$

\section{B) Khilafat and the Non-cooperation movements (1921-1923)}

After World War I, the Bengali middle class, both Hindus and Muslims, were frustrated with the deteriorating living condition and low wages. Unemployment motivated them to join the nationalist movement. This was also the period that saw the rise of Indian capitalists. The Marwari businessmen of Calcutta made considerable wealth, but the working class demanded an increase in wages and reduction in work hours. It was in this phase that Gandhi appeared in Indian politics. Gandhi's policy of ahimsa (non-violence) and satyagraha (passive resistance) satisfied moderates, pacified revolutionary terrorists, and the dominant section of the peasantry. Gandhi was able to organize a nationalist struggle against foreign rule. ${ }^{184}$

In organizing the satyagraha, Gandhi made use of three political networks: panIslamic groups, home rule leagues, and the satyagraha sabha, started in Bombay. Gandhi maintained a close relation with the leaders of the Khilafat movement that was extremely popular the 1920s. The Khilafat movement had three major demands: restoration of the Caliphate over Muslim sacred places; continuance of Muslim sovereignty in Arabia, Iraq, Palestine, and Syria; and the freedom to defend and practice their faith. Nawab Syed Nawab Ali Chowdhury and Maulana Shah Sufi Mohammad Abu Bakr in Islam Darshan and Banganoor indicated that it was

\footnotetext{
${ }^{183}$ BL, Government of Bengal, Sir Philip Hartog, Papers as Chairman of the Education Committee of Indian Statutory Commission, 1928-29, MSS EUR 221/57; Editorial, Soltan, Report on Newspapers and Periodicals in Bengal, May 11, 1927. Editorial, Hanifi, Report on Newspapers and Periodicals in Bengal, March 12, 1928. WBSA, Government of Bengal, Education, Proceedings of the Government of Bengal, February1915, File No: 1M/6 -1, Proceedings No: 122.

${ }^{184}$ See Sarkar, Modern India 1885-1947, 168-88.
} 
important for the British government to retain the Caliphate and protect sacred Muslim places in order to maintain peace in India. The restoration of the caliphate was important for the existence of the community. ${ }^{185}$

The Central Khilafat Committee maintained a radical stand, and it was this group that started the non-cooperation movement at the Central Khilafat Conference in 1919. It organized the non-cooperation movement in four stages: boycott of titles, then civil services, followed by police and army, and finally, non-payment of taxes. The non-cooperation movement spread rapidly all over Bengal. In Bengal, the Dhaka Khilafat committee organized 43 meetings that demanded swaraj (independence) and preached boycott. Al-Islam and Islam Darshan indicated that for Muslims, the non-cooperation movement had two goals: the fulfillment of the Khilafat movement's demands and freedom from colonial rule. Muslims wanted to restore the caliphate but the government paid no attention to it. This forced a section of the Muslim community to join the non-cooperation movement. The Khilafat leaders advocated for Hindu-Muslim unity and were willing to give up the slaughter of cows. Also, the new leaders of the Bengal Provincial Muslim League wanted to develop the country, so they united with the Congress and the leaders of the Khilafat movement. Both the movements developed an anti-British attitude, boycotted British goods, opposed secular Western education, and wanted to establish schools that provided instruction in Arabic, Bengali, and Persian. ${ }^{186}$

\footnotetext{
${ }^{185}$ Ibid. Chandiprasad Sarkar, The Bengali Muslims: A Study in their Politicization 1912-1929 (Calcutta: K.P.Bagchi \& Company, 1991), 128-29. Editorial, Banganoor, Bangali Musalman Sampadito Samoyik Patro, January 1920. Maulana Shah Sufi Mohammad Abu Bakr, "Khilafat Proshongo," Islam Darshan, Bangali Musalman Sampadito Samoyik Patro, April 1920. Editorial, Islam Darshan, Bangali Musalman Sampadito Samoyik Patro, October 1920.

${ }^{186}$ See Sarkar, The Bengali Muslims: A Study in their Politicization 1912-1929, 78-81\&100; Editorial, Al-Islam, Bangali Musalman Sampadito Samoyik Patro, January 1921; Editorial, Islam Darshan, Bangali Musalman Sampadito Samoyik Patro, February 1922. See Sarkar, Modern India 1885-1947, 196-7. Muslim League: After the Partition of Bengal in 1905, the new Muslim majority province of East Bengal and Assam converted Dhaka from a mufassil town to a capital city. After the Partition, the Muslims of Aligarh joined the Dhaka Muslims to present a
} 
The idea to boycott British goods like the swadeshi movement in 1905 was also extended to educational institutions. In the 1920s, both the Indian National Congress and the AllIndia Muslim League boycotted government schools, councils, and courts. The boycott of educational institutions was more effective in Bengal, where approximately 20 headmasters or principals, resigned per month until April 1921. Bamford's confidential History of the Noncooperation and Khilafat Movements showed that the movements had a huge influence on college education. As a result of the non-cooperation movement, arts colleges in Calcutta and government colleges in Chittagong, Hoogly, and Krishnagar were closed for several days. Between 1919 and 1922, students in government colleges declined by 15 percent and in aided colleges by eight percent. The number of pupils in high schools declined from 218,070 in 1919 to 190,630 in 1921 . This decline was mainly because of the influence of the non-cooperation movement. A number of nationalist schools were established in different parts of India, such as the Jamia Milia Islamia in Aligarh. The famous Bengali poet Kaji Nazrul Islam in Dhumketur Pathe indicated that the colonial government only exploited the country and the method of petition would never bring about complete independence. The Choltan indicated that complete independence could be achieved through the Khilafat and the non-cooperation movements. This independence would benefit Muslims more than Hindus, and hence it was necessary to boycott

\footnotetext{
deputation to Viceroy Minto in the fall of 1906. The deputation was the beginning of the Muslim League. Khawaja Yusuf Shah of Amritsar along with Mohsin-ul-Mulk, the secretary of the Aligarh College, organized a deputation to Shimla. 35 young Muslim leaders headed by Aga Khan arrived at Shimla on October 1, 1906 to present the deputation. "They demanded that Muslim representation should commensurate not merely with their numerical strength but also with their political importance and the value of the contribution, which they make to the defense of the Empire."(Wolpert, 288) Lord Minto gave full support to the deputation. Two months after the Shimla Deputation, the same deputation selected another 35 delegates from all the provinces of India and Burma. They met at Dhaka on December 30 to start the All India Muslim League. The first joint secretaries of the League were Mohsin-ul-Mulk and Nawab Viqur -ul-Mulk, Mushtaq Khan. For more information see See Wolpert, A New History of India, 288-9.
} 
government schools, colleges, and jobs. However, these nationalist institutions dried up when the movements failed to achieve any considerable success. ${ }^{187}$

Although no impact was felt on primary education, John Berwick in his dissertation provides a detailed account of how students responded to the movement. Students of the Calcutta Madraasah organized a strike and started a national institution called the Madrassah Islamia. Students of the Chittagong College and Madrassah also boycotted classes, and those of the Jagannath College of East Bengal approached the principal to nationalize the college. However, Berwick argues that Presidency College students maintained their allegiance to the colonial government. For the British, this was a tribute to the British educators and the Indian teachers of the college valued this connection. However, students' movements were not independent of the Indian National Congress, and they failed to organize a stable campaign against colonial rule. Yet, Berwick considers the boycott of colleges and demonstrations organized by the students to be an important part of the non-cooperation movement in Eastern India. ${ }^{188}$

At the same time, a few English-educated Muslims including Fazlul Huq realized that cooperation with the government helped in securing political power. He along with Nawab Habibullah opposed the non-cooperation movement. Huq opposed the idea of boycotting educational institutions, as it wasted public money collected from people as taxes. Maulvi Abdul Karim in his 1920s speech indicated that the boycott of British goods was never really the solution to the problem. It was important to use goods produced in India, but it was unnecessary

\footnotetext{
${ }^{187}$ See Sarkar, Modern India 1885-1947, 206-7; Kazi Nazrul Islam, "Dhumketur Pathe," Dhumketu, Bangali Musalman Sampadito Samoyik Patro, October 26, 1922; WBSA, Government of Bengal, Education Department, Proceedings of the Government of Bengal, December 1925, Proceedings No: 226, File No: 8-R-16 (3) of 1924; Editorial, Choltan, Bangali Musalman Sampadito Samoyik Patro, September 27, 1921.

${ }^{188}$ See Berwick, "Chatrasamaj: the Social and Political Significance of the Student Community in Bengal 1870 1922," 310-49.
} 
to pass resolutions on the boycott of British goods and government jobs. He believed that Muslims had to cooperate with the government in order to receive further concessions. ${ }^{189}$

Although the movements failed, they successfully politicized Indian Muslims. As a result of this politicization, the Muslim members of the Bengal Legislative Council demanded provisions in the budget for the improvement of the community. They regretted that the Calcutta University never had a Muslim vice-chancellor and demanded proper representation in various departments of the government. Muslim leaders also expressed their grievances over the shortage of careers for young educated Muslims. ${ }^{190}$

Newspapers and periodicals represented a variety of opinions. A section of the Muslim community supported the non-cooperation movement, while others believed that the movement hindered the progress of the community. Abdul Faruk and Mohammad Ismail Hussain Siraji argued that the non-cooperation movement, which started in Calcutta, had a disastrous influence on Muslims. Hindus did not quit government schools and jobs, whereas Muslim institutions went on a strike. The Shariat Islam indicated that Muslim students were most affected by the noncooperation movement as they had to leave schools and colleges. Finally, an article published in Saogat indicated that the non-cooperation movement was organized to demand full independence, but India was still not ready for complete independence. ${ }^{191}$

\footnotetext{
${ }^{189} \mathrm{BL}$, Government of Bengal, Presidential Address delivered at the Annual session of the Bengal Presidency Muslim League, 1920, IOR/General Reference Collection-8023; See Sarkar, The Bengali Muslims: A Study in their Politicization 1912-1929, 101-43.

${ }^{190}$ See Sarkar, The Bengali Muslims: A Study in their Politicization 1912-1929, 101-43; See Shah, In Search of an Identity: Bengali Muslims 1880-1940, 130-1.

${ }^{191}$ Editorial, Islam Darshan, Bangali Musalman Sampadito Samoyik Patro, August 1924; Editorial, Al Islam Bangali Musalman Sampadito Samoyik Patro, August 1930; Abdul Kaseem, "The Story of the People." Choltan, , Bangali Musalman Sampadito Samoyik Patro, October 5, 1923; Abdul Kasem argued that a few Muslims joined the Non-cooperation and the Khilafat movements.
} 
The Khilafat and the non-cooperation movements were successful to a great extent in generating an anti-British attitude. They united Hindus and Muslims temporarily and students boycotted government schools and colleges. But the nationalist educational institutions started by Hindus did not always include students from the Muslim community. Similarly, the Dhaka University, which was predominantly meant for Muslims, appointed Hindus as teachers and administrators. This aggravated the communal situation of the province. Moreover, after the collapse of the non-cooperation movement in 1922, Hindu revivalist groups became powerful. Local Hindu organizations such as the Hindu Sabha of Pabna, educated its followers in communal practices or traditions such as the playing of music in religious procession. Muslim children in government and municipal schools were forced to sing the Bande Mataram as the national song. The Muslim community resented these activities. However, by this phase the effects of the Lucknow Pact were also evident. The pact granted Muslims just 34 percent of the elected seats in the Bengal Legislative Council. These grievances forced Jinnah to criticize the Congress and Gandhi for establishing a Hindu Raj in the country. In these circumstances, the colonial government was unable to develop a stable education policy for Muslims beyond the establishment of separate schools. Colonialism along with Hindu imperialism forced Muslims to strengthen their demand for reservation of seats in government educational institutions. Finally, the Bengal Pact of 1923 made the last attempt to unite the two communities. ${ }^{192}$

\footnotetext{
${ }^{192}$ Harun-or-Rashid, The Foreshadowing of Bangladesh: Bengal Muslim League and Muslim Politics 1936-1947 (Dhaka: Asiatic Society of Bangladesh, 1987), 23-8. Suranjan Das, Communal Riots in Bengal 1905-1947 (New Delhi: Oxford University Press, 1991), 59-87. Jinnah's Presidential Address, $1^{\text {st }}$ series (1938). Lucknow Pact: In Hindu and Muslim moderate leaders reached a common ground through the famous Lucknow Pact, where the Congress accepted separate electorates and Muslims agreed to under representation in majority areas such as Bengal and over representation in Bombay and the United Provinces.
} 


\section{The period of declining Hindu-Muslim Unity}

\section{A) The Bengal Pact of 1923 and its impact on the progress of Muslim Education}

After the collapse of the non-cooperation movement, the nationalist movement underwent several shifts between 1922 and 1927. Gandhi's promise of swaraj (independence) in the 1920s failed, and the rift between the Swarajists (Indian leaders who opposed Gandhi after the collapse of the non-cooperation movement) and no-changers (supporters of Gandhi even after the failure of the non-cooperation movement) increased. This decrease in unity led to communal riots. There was a split in the Congress at the Gaya session in 1922 over whether the Congress should participate in the council elections. The Congress rejected the proposal to contest the Bengal Council elections but Chittaranjan (C.R) Das and Motilal Nehru set up the Swaraj Party in 1923 and decided to contest the elections. They won the elections in 1923 with 47 out of the 85 general Hindu and Muslim seats, including the 21 Muslim constituencies. On the basis of this victory, Das proposed a new pact between Hindus and Muslims. They made an effort to unite the two communities and promised Muslims 55 percent reservation in the administrative posts after attaining swaraj. Both Das and M. Nehru assumed that unity between the two communities could be reached, if Muslims gave up cow killings and Hindus stopped playing music in front of mosques. ${ }^{193}$

The Bengal Hindu-Muslim Pact, also known as the C.R. Das Pact, assured elite Muslims administrative jobs and political participation. After winning the elections, the swarajists wanted to form a responsible self government. Das introduced a system of free primary education, medical relief, and proper sanitation for people living in slums. The Swaraj

\footnotetext{
${ }^{193}$ See Sarkar, Modern India 1885-1947, 226-33.
} 
Party awarded grants to hospitals and schools and Das attempted to improve the living condition of the middle class and the poor by providing the benefits of self-government within the limitations of colonial rule. The party also established links with businessmen for financial support. Finally, Das included Muslim councilors from separate electorates in order to build a nationalist organization, which incorporated diverse and antagonistic elements of Bengal politics. ${ }^{194}$

The success of the pact was short lived, as they were unable to protect 80 Indians who were detained for allegedly being terrorists. Das was forced to cooperate with the government in 1925 for the release of the prisoners. However, immediately after Das's death in June 1925, the party was divided into several factions, and his followers did not recognize the importance of Muslim support in the province. For example, the Muslim councilors of the Swaraj Party walked out of the Calcutta Corporation over the 'pir-burial' issue and the resignation of the Muslim Deputy Mayor H.S. Suhrawardy. The pact failed to satisfy the Marwari businessmen, on whom the swarajists depended for financial support. The privileged Hindus were afraid of losing their positions to Muslims. The pact was actually a threat to the advantages enjoyed by the Hindu landed, commercial, and professional classes. ${ }^{195}$

The Bengal Pact did not oppose Hindu communalism or the activities of the Hindu Mahasabha. Movements such as the Shuddhi and Sangathan, started by the Hindu Mahasabha in

\footnotetext{
${ }^{194}$ Ibid. Rajat Ray, Urban Roots of Indian Nationalism: Pressure Groups and Conflict of Interests in Calcutta City Politics, 1875-1939 (New Delhi: Vikas Publishing House Pvt Ltd, 1979), 110-4.

${ }^{195}$ Mushirul Hasan, "Communalism in the Provinces: A Case Study of Bengal and the Punjab 1922-1926," in Communal and Pan-Islamic Trends in Colonial India, ed. Mushirul Hasan (New Delhi: Manohar Publications, 1981), 248-60; See Chattopadhyay, "Muzaffar Ahmad, Calcutta, and Socialist Politics, 1913-1929," 152-3; See Sarkar, Modern India 1885-1947, 231-3. See Ray, Urban Roots of Indian Nationalism: Pressure Groups and Conflict of Interests in Calcutta City Politics, 1875-1939, 117-8; After J.M. Sengupta became the Mayor of the Calcutta Corporation, a huge debate started over whether the body of a particular pir, buried in the municipal market, be exhumed. The European and Hindu councilors wanted to exhume the body on medical grounds. The Muslim councilors opposed it and walked out of the Corporation. Second, after the resignation of H.S. Suhrawardy there were communal riots in Calcutta.
} 
1923 created a feeling of distrust among Muslims. Dainik Basumati and Ananda Bazaar Patrika blamed Muslims for their backwardness. They criticized maulvis for inciting Muslims against Hindus and accused Muslim gangs of abducting Hindu women and killing Swami Sradhananda.

This was mainly because Muslims opposed the Hindu revivalist movements started by the Swami. Similarly, Dainik Soltan and Soltan, argued that Hindus opposed the development of the Muslim community. The Congress was a Hindu organization, and the demands of the Muslim community were never respected. The Calcutta University did not hire Muslim professors except for Arabic and Persian faculty members, and the government did not spend enough money on Muslim education. Some colleges such as the Rajshahi College did not even have Arabic and Persian teachers. The pact promoted unity at the elite level but never really solved the HinduMuslim problem. ${ }^{196}$

After the pact was abrogated in 1926, a volatile political situation existed in Bengal. Political leaders and conservative groups, such as Jamiat-i-Ulema and Tanzeem-ul-Mussalman promoted communal hatred. The activities of the Cow Protection League decreased the sale of cows in Calcutta. This increased Muslim resentment. At the same time, educated Muslims struggled for jobs and seats in the Bengal Legislative Council. The social crisis and the growing

\footnotetext{
${ }^{196}$ Editorial, Ananda Bazar Patrika Report on Newspapers and Periodicals in Bengal, April 4, 1926. Editorial, Visamitra, Report on Newspapers and Periodicals in Bengal, December 25, 1926.

Editorial, Dainik Basumati, Report on Newspapers and Periodicals in Bengal, December 26, 1926. Editorial, Dainik Soltan, Report on Newspapers and Periodicals in Bengal, December 26, 1926. Editorial, Dainik Soltan, Report on Newspapers and Periodicals in Bengal, January 28, 1927. Tanika Sarkar, "Communal Roots in Bengal," in Communal and Pan-Islamic Trends in Colonial India, ed. Mushirul Hasan (New Delhi: Manohar Publications, 1981), 302-13 in Communal and Pan-Islamic Trends in Colonial India, ed. Mushirul Hasan (New Delhi: Manohar Publications, 1981)
} 
communal tension forced Muslims to demand reservation in educational institutions and separate schools. $^{197}$

The report of the Director of Public Instruction for 1925 and 1926 showed that in 1926, the presidency had a total of 467 madrassahs with 42,527 students. Muslims wanted reservation in government and aided schools, and also stipends and free studentships. The Islamia College was established for Muslims in 1926. There were two Islamic Intermediate colleges in the province: one at Dhaka and the other at Serajganj. They subsidized fees and maintained an Islamic culture and tradition. These institutions provided instruction in Mathematics, Physics, and Chemistry and also appointed teachers who were qualified to teach English, History, and Political Economy ${ }^{198}$

Despite these facilities, the Muslim community did not make an overwhelming improvement in education. In 1926, Calcutta had 429 primary schools with 28,035 students, of which 17,112 were Hindus and 10,562 were Muslims. Muslim students were hardly visible in higher education. Muslims made up only 18 percent of the total teaching staff in nongovernmental schools and just 24 percent in government schools. The table below shows that although the number of Muslim teachers and inspecting officers increased in Bengal after the Montagu-Chelmsford reforms, it was insufficient in comparison to the total population. ${ }^{199}$

\footnotetext{
${ }^{197}$ Ibid. Mushirul Hasan, "Communalism in the Provinces: A Case Study of Bengal and the Punjab 1922-1926," in Communal and Pan-Islamic Trends in Colonial India, ed. Mushirul Hasan (New Delhi: Manohar Publications, 1981), 248-60.

${ }^{198}$ Proceedings of the Government of Bengal, September 1927, CSA, Education File No: 4-C 23(1), Proceedings No: 22-23. Report of the Director of Public Instruction in Bengal 1925-26, September 1927, CSA, Education File No: Edn 8 R-1 (3), Proceedings No: 8.. Suranjan Das, Communal Riots in Bengal 1905-1947 (New Delhi: Oxford University Press, 1991), 59-87.

${ }^{199}$ Ibid. Report of the Director of Public Instruction in Bengal 1925-26, September 1927, CSA, Education File No: Edn 8 R-1 (3), Proceedings No: 8.
} 


\begin{tabular}{|l|l|l|l|l|}
\hline & $\begin{array}{l}\text { No. of Muslims } \\
\text { holding } \\
\text { appointments as } \\
\text { teachers }\end{array}$ & $\begin{array}{l}\text { No. of Muslims } \\
\text { holding } \\
\text { appointments as } \\
\text { inspecting offices }\end{array}$ & $\begin{array}{l}\text { \% of teaching } \\
\text { appointments held } \\
\text { by Muslims }\end{array}$ & $\begin{array}{l}\text { \% of inspecting } \\
\text { appointments held } \\
\text { by Muslims }\end{array}$ \\
\hline Presidency & 31 & 29 & 32.6 & 50.0 \\
\hline Burdwan & 10 & 16 & 17.8 & 22.2 \\
\hline Dhaka & 27 & 39 & 20.7 & 46.4 \\
\hline Rajshahi & 29 & 28 & 28.15 & 41.8 \\
\hline Chittagong & 6 & 30 & 14.3 & 58.8 \\
\hline Total & 103 & 142 & Average 22.71 & Average 43.84 \\
\hline
\end{tabular}

(Source: WBSA, Government of Bengal, Education Department, Report of the Director of Public Instruction in Bengal 1925-26, September 1927, Proceedings No: 8, File No: Edn 8 R-1/3).

Primary education was necessary for poor Muslim peasants and they mostly preferred madrassahs and maktabs. Muslim organizations, such as the Khulna District Muhammadan Association and the Faridpur Anjuman-i-Islamia, expressed their discontent over the school curriculum and the curriculum adopted by the Dhaka University. The curricula did not suit the needs of the prospective Muslim students from East Bengal. Under the reform madrassah policy, Persian was replaced by English, which was not always preferred by the rural Muslim masses. Moreover, most Muslims could not pay the fees to attend the aided schools and the Dhaka University was beyond the financial capacity of rural Muslims. As a result Muslim organizations demanded the implementation of the Bengal Rural Primary Education Bill (see below) in order to improve mass education. The abandonment of the non-cooperation movement followed by the failure of the Bengal Pact forced Hindus and Muslims to seek different political paths for the advancement of their respective communities. Many newspapers such as Kandi Bandhav and Ganavani in 1927 urged Hindus and Muslims to unite. Kaji Nazrul Islam in the article "HinduMuslim" suggested that riots did not produce any constructive results. Muslim maulvis and 
Hindu pundits incited people against each other. Sadly enough, the political situation and the educational reforms only multiplied the grievances of the two communities. ${ }^{200}$

Education policies overlooked the needs of the masses, and grievances increased over inadequate education facilities and delay in the introduction of the Bengal Rural Primary Education Bill. Separate educational institutions did not improve the quality of education. Only a section of the Muslim population could afford these schools, and the education curriculum within these separate schools was unsuitable for securing government jobs. After a point, even the colonial government found it difficult to support these separate educational institutions. This systematic change in education policies widened communal divisions. Finally, the Bengal Pact attempted to unite the two communities through several reforms. It was probably the last phase of Hindu-Muslim unity. After the failure of the pact, there were violent riots all over the province. In this volatile situation, Muslim members of the Bengal Legislature demanded the implementation of the Bengal Rural Primary Education Bill of 1930. The next section will evaluate the debates over the implementation of the bill.

\section{B) The Bengal Rural Primary Education Bill of 1930 (1927 -1930)}

The period between 1927 and 1930 saw contradictory and complex political developments. The all-white Simon's Commission announced on November 8, 1927, had a drastic influence on Indian society. It considered Indians incapable of developing a constitution for themselves. Politicians such as Tej Bahadur Sapru and Mohammad Ali Jinnah united with the Congress to formulate the Dominion Status constitution. At the same time, the movement to

\footnotetext{
${ }^{200}$ See Shah, In Search of an Identity: Bengali Muslims 1880-1940, 204-19. From the Members of the Faridpur Anjuman-i-Islamia, 1933, BL, MSS EUR G119/2 From the members of the Khulna District Muhammadan Association, 1933, BL, MSS EUR G119/3 Kaji Nazrul Islam, "Hindu-Muslim," Ganabani, Bangali Musalman Sampadito Samoyik Patro, September 1926. Editorial, Kandi Bandhav, Report on Newspapers and Periodicals in Bengal, June 1, 1927. Editorial, Ganavani, Report on Newspapers and Periodicals in Bengal, June 7, 1927.
} 
boycott the Simon's Commission, demanded complete independence and initiated a variety of socio-economic changes. ${ }^{201}$

The Simon's Commission also addressed some of the problems related to higher education. It suggested that the province did not have significant number of colleges in rural areas. As a result, students from villages found it difficult to continue their education in the city. The commission indicated that in order to improve the condition of higher education, universities should only admit a few students and provide them with extensive opportunities for research. The commission praised the Dhaka University for uplifting the status of the Muslim community and recommended the establishment of boards for the improvement of Muslim education. Muslims, who supported the commission, refused to give up separate electorates and believed that the commission recognized the problems of the Muslim community and sincerely wanted to improve their social status. ${ }^{202}$

Following the announcement of the Simon's Commission, the animosity between Hindus and Muslims further increased. This was mainly because of Motilal Nehru's report. Motilal Nehru's report gave several concessions to the Hindu Mahasabha and agreed to reserve seats for Muslims in the Central Legislature and also in the provinces where Muslims were minorities. M. Nehru wanted both communities to support the report. But Nehru was more concerned about the Mahasabha than Muslims. Although nationalist Muslims supported him, he believed that it was possible to overcome Muslim opposition because there was no single

\footnotetext{
${ }^{201}$ See Sarkar, Modern India 1885-1947, 261-2. Muslim leaders under Jinnah agreed to accept joint electorates, if the following proposals were accepted: joint electorates reserved seats for minorities; Sind, North West Frontier Province, and Baluchistan would be considered Muslim majority provinces; Muslim representation in Punjab and Bengal would be made according to the population; and finally, Muslim representation in the Central Legislature would not be less than one-third. The All-India Congress accepted Jinnah's offer.

${ }^{202}$ Mohammad Abdullah Al-Masum, British Amole Banglar Muslim Sikha: Samasya o Prashar (Dhaka: Bangla Academy Press, 2008), 334-5.
} 
Muslim organization representing the community. This attitude of Nehru forced Jinnah to rejoin the Shafi group of the Muslim League. They drafted the 'Fourteen Points' charter that represented the demands of the Muslim community. Muslims reorganized themselves at the All Parties Muslim Conference, where they identified the Congress as a Hindu organization, unable to protect Muslims. Muslim leaders at the All Parties Conference in 1928 were offended by the views expressed by the representatives of the Hindu Mahasabha. The latter opposed the system of reservation of seats. The representatives also objected the creation of a new Muslim province. This attitude of the Hindu conservatives aggravated the social situation of the province. They feared that Hindu domination would hinder the progress of the community. Similarly, the Muslim Graduate Association feared that after colonial rule they would be dominated by Hindus. Hence, they decided to cooperate with the Simon's Commission. Newspapers such as the Muslim Darpan campaigned for separate electorates and educational institutions, and insisted that the Muslims of Bengal should cooperate with the Simon Commission in order to improve their economic situation. ${ }^{203}$

\footnotetext{
${ }^{203}$ Uma Kaura, Muslims and Indian Nationalism: The Emergence of the Demand for India's Partition 1928-1940 (New Delhi: Manohar Book Service, 1977), 28-43. Notes on Muslim Education submitted to the Education Committee, June 1929, BL, MSS EUR221/52 (a) and (b). The Muslim Graduate Association demanded forty percent reservation of seats for Muslims on all legislative bodies and abolition of special electorates such as the Bengal Mahajan Sabha. The Muslim graduates insisted on having separate Muslim boards, and allotment of funds for primary and secondary education of the community. They also indicated that provision had to be made for secular and religious instruction, and wanted Urdu to be the medium of instruction for Muslim boys. ${ }^{203}$ Editorial, Muslim Darpan, Bangali Musalman Sampadito Samoyik Patro, October 1928, 4. Editorial, The Soltan January 24, 1928 Report on Newspapers and Periodicals in Bengal, 5 of 1928. Editorial, The Al Hedayet, May, 1928, Report on Newspapers and Periodicals in Bengal, 28 of 1928. A poem published by Abdul Aseem Khan Choudhury in AlHedayet suggested that there was no freedom for Muslims. The Arya-Samajists wanted to crush the power of Muslims. Editorial, The Jehad, April, 1922, Report on Newspapers and Periodicals in Bengal, 27 of 1927. The Arya Samaj procession insulted Muslims and mosques, and the government did not take any action against this incident. Editorial, The Ananda Bazaar Patrika, December 29, 1927, Report on Newspapers and Periodicals in Bengal, 1 of 1928. The tension between the two communities was so strong that there was no room for mutual trust and reliance. Hindus never interfered with other religions but Muslims embittered the feelings of Hindus. Editorial, The Tarqqee, May 3, 1927, Report on Newspapers and Periodicals in Bengal, 27 of 1927. Hindus aggravated the communal situation of the country by celebrating the birthday of Shivaji and opposed Mughal rulers.
} 
Throughout 1928 and 1929 a convoluted relationship existed between Hindus and Muslims. There were riots all over the province and historians have argued that the Bengal Rural Primary Education Bill of 1930 was one of the pressing needs of the time. The budget of the Government of Bengal for 1925 and 1926 showed that the total income of the government was eleven crore rupees, of which only three crore were spent on developing the province. Maulvi Abdul Karim indicated that there was no scope for correlating education with employment. The existing system of primary education did not suit the needs of people. He insisted that primary education had to be related to agriculture and village art and crafts. Similarly, Khan Sahib Abdus Sattar argued that most village primary schools had just one teacher appointed by the district board, and opened once or twice a month. Karim and Sattar highlighted the need for a stable primary education system. $^{204}$

Extensive debates continued in the Bengal Legislature between Hindus and Muslims over the Bengal Rural Primary Education Bill of 1930. Educated Hindus, such as Babu Joginchandra Chakravarti and Babu Bejoy Krishna Ghose, argued that the money allocated by the Bengal Government for education was insufficient. A grant of two lakh rupees to the Calcutta University and three lakh and ninety two thousand rupees for education was not enough for educating the entire population of Bengal. Kumar Shib Shekhareswar Roy and Narendra Kumar Basu opposed the bill. They indicated that the bill imposed heavy taxes on Hindus. The Hindu zamindars had to pay 25 percent of their total revenue, and the colonial government ignored the feelings of Hindus. In other words, rich Hindus were unwilling to pay for Muslim education. ${ }^{205}$

\footnotetext{
${ }^{204}$ India. The Bengal Legislative Assembly Council Proceedings, General Discussion of the Budget of the Government of Bengal for 1928-29, (Calcutta: GPO, 1928)

${ }^{205}$ India. The Bengal Legislative Assembly Council Proceedings, The Bengal (Rural) Primary Education Bill, 1930, (Calcutta: GPO, 1931)
} 
However, ministers such as Maulvi Wahed Hussain and Khan Bahadur Maulvi Syed Muqbul Khan, demanded free and compulsory education for Muslims. They insisted that diarchy was unsuitable for the needs of the country. There was no cooperation between the government and the elected ministers. Azizul Huque argued that even after Muslim willingness to pay the extra taxes, the colonial government deferred the introduction of the bill. The members of the Bengal Legislature were involved in a heated discussion over the implementation of the bill. Muslims faced tough opposition from the Hindu leaders. The debate over the bill alienated many Muslims, as compulsory primary education was needed to improve the educational condition of the community in rural areas. However, Hindu and Muslim leaders were unable to come to a unanimous decision over the Rural Primary Education Bill. ${ }^{206}$

The bill was also criticized by the colonial educationist, Sir Philip Hartog. Hartog who suggested that compulsory primary education was good in theory but not in practice. The rapid expansion of primary education would produce disastrous results for India and also Bengal. The number of primary schools increased, but the method of instruction was unsystematic and uneconomic. Secondary and higher education suffered. Schools had inefficient teachers and private tutoring was almost universal. In Bengal, the Government of India provided financial assistance to just eight hundred and ninety eight recognized schools, while the unaided institutions struggled for financial aid. ${ }^{207}$

Despite several arguments and criticisms against it, the bill was made into a law in 1930. The law was first introduced in Birbhum, Bogra, Chittagong, Dinajpur, Mymensingh, Noakhali, and. Pabna. A committee of 27 members was set up to inspect the proper

\footnotetext{
${ }^{206}$ Ibid. See Shah, In Search of an Identity: Bengali Muslims 1880-1940, 204-19.

${ }^{207}$ BL, Sir Philip Hartog: Papers as Chairman of Education Committee of Indian Statutory Commission 1928-1929, MSS EUR 221/58.
} 
implementation of primary education in these districts. The committee recommended a standard curriculum for improving primary education. The Bengal Primary Education Fund was also established to monitor the expenditure of the committee on primary education. The bill remained one of those incidents that further widened the distance between the two communities, as Hindus opposed the bill and Muslims to a great extent supported it. ${ }^{208}$

Although the bill was implemented, it was severely criticized by both Hindu and Muslim members of the legislature. For example, Abdul Karim indicated that the Primary Education Act of 1930 did not develop a proper curriculum that improved primary education. The course of study did not meet the requirements of Muslim students. Maktabs were not considered as primary schools, which provided education in Arabic and Persian. This discouraged poor Muslims from sending their children to schools. The government spent a lot of money on administration but inadequate financial aid was allocated for primary education. There was no major improvement in the condition of primary education. The literacy rate improved from three percent in 1881 to eight percent in 1931. According to the census of 1921, only 9.5 percent of the total Muslim male population was educated. It increased to 9.8 percent in 1931. This increase of 0.3 percent provided a very gloomy picture of the state of Muslim education. The Muslim community believed that it was the duty of the government to provide all the necessary facilities for the improvement of Muslim education. Leaders such as Nur Ahmed acknowledged the government's contribution, but suggested that it was inadequate in comparison

\footnotetext{
${ }^{208}$ India. The Bengal Legislative Assembly Council Proceedings, The Bengal (Rural) Primary Education Bill 1930, (Calcutta: GPO, 1931), 286-305.
} 
to the total Muslim population. There was a huge demand for government assistance to improve Muslim education. ${ }^{209}$

Lack of resources and absence of financial assistance were the two major problems throughout the early decades of the twentieth century. Even after the transfer of the Education Department to the elected ministers, the government did not assign enough grants to the department. Despite the introduction of the reformed madrassah system and the establishment of separate schools, Muslims progressed very little in comparison to Hindus. By 1932, arts colleges in Bengal had only 13 percent of the total Muslim male population and one percent of the total Muslim female population of the province. There were hardly any Muslim girls in medical, engineering, and commercial schools. However, the political situation of the province constantly fueled the idea that Muslim dreams and aspirations were different from those of Hindus. Historians have argued that during the 1920s and 1930s Muslims were unsure of their political position, but grievances over jobs, representation, and education strengthened a sense of separate identity. The colonial government designed policies that did not prove advantageous for any of the communities. Moreover, the two communities in an attempt to secure further privileges for themselves were always at conflict with each other. ${ }^{210}$

\footnotetext{
${ }^{209}$ Editorial, Viswamitra April 12, 1927, Report on Newspapers and Periodicals in Bengal, 17 of 1927; Nareshchandra Roy, "Hindu-Muslim relation," The Calcutta Review, Report on Newspapers and Periodicals in Bengal, May 1927; Editorial, The Suniti, June 11, 1927, Report on Newspapers and Periodicals in Bengal, 26 of 1927; Editorial, The Swadeshi Bazaar, July 27, 1929, Report on Newspapers and Periodicals in Bengal, 31 of 1929; Editorial, The Mohammadi, March 2, 1928, Report on Newspapers and Periodicals in Bengal, 8 of 1928; The Bengal Legislative Assembly Council Proceedings, "General Discussion on the Budget," 1935 The Bengal Legislative Assembly Council Proceedings, "Non Official Resolutions," 1938

${ }^{210}$ See Sarkar, The Bengali Muslims: A Study in their Politicization 1912-1929, 228. See Sarkar, Modern India 1885-1947, 257-61.
} 


\section{The increase in animosity between Hindus and Muslims: from the Civil Disobedience Movements to the India Act of 1935 (1930-1935)}

This section shows how the animosity between Hindus and Muslims increased over education policies formulated between the Civil Disobedience movements (1930-32) and the India Act of 1935. Towards the end of the second decade of the twentieth century, Gandhi encouraged the boycott of British goods. However, he rejected Jawaharlal Nehru's independence proposal at the Madras session of the Congress in 1927. At the Calcutta session the next year, Gandhi accepted the idea of Dominion Status proposed by Jawaharlal Nehru. The Congress opted for Civil Disobedience and Purna Swaraj (complete independence) if the British had failed to grant Dominion Status by 1929. However, the Congress rejected Lord Irwin's offer and adopted the policy of complete independence. Gandhi on January 26, 1930 launched the first Civil Disobedience movement. ${ }^{211}$

The first Civil Disobedience movement also coincided with the Great Depression, which had a major impact on Indian society. First, the prices of commodities decreased, especially those of agricultural products. Second, there was a major crisis in the export-oriented economy. In this critical financial situation, Indians boycotted the legislative council elections of 1930. However, the Hindu-Muslim problem remained unsolved. Muslim leaders such as Aga Khan, Muhammad Shafi, and Muhammad Ali Jinnah encouraged Muslims to campaign against

\footnotetext{
${ }^{211}$ See Sarkar, Modern India 1885-1947, 281-92. Lord Irwin's offer on October 31, 1929 complicated the political situation. Lord Irwin declared that Dominion Status was a 'natural issue of India's constitutional progress' and proposed to organize a round-table conference after the publication of the Simon Report. On November 2, 1929, Gandhi, M. Nehru, and Malaviya put forward four major conditions before participating in the conference: the conference had to discuss the issue of dominion status, the British had to accept the proposal immediately, the Congress would have a majority representation at the conference, and finally, there would be a policy of general conciliation. Lord Irwin rejected these conditions, and this failure started a new phase in the anti-imperialist movement in India. Civil Disobedience movements did not coincide with any labor movements. However, unlike the Non-cooperation movement lawyers and students did not boycott educational institutions or government jobs. But peasants and business groups supported the civil disobedience movements. By this time, the Congress was also a strong organization particularly in rural areas.
} 
the movement launched by Gandhi. Mohammad Ali Jinnah urged Muslims to oppose the Congress, which was primarily a Hindu organization. Hence, Muslims were encouraged to stay away from the movement. There was hardly any unity between Hindus and Muslims during this period. $^{212}$

Following the first and second Civil Disobedience movements, the Communal Award of 1932 was an inevitable outcome of the Hindu-Muslim conflict. In the Bengal Council, Hindus had 46 and Muslims had 39 seats. The situation immediately changed after the award and Muslims held majority of the seats. Muslims enjoyed a stronger position, and the award forced congressmen to join Hindu communal leaders. Many Muslim congressmen left the Congress, considering it to be a Hindu institution. Muslims feared that the leaders of the country wanted to establish Hindu rule, which was unacceptable for the Muslim community. Hindus denounced the award, whereas Muslims united in its defense. Newspapers such as the Watan, argued that stubbornness on the part of the Congress and the imprudent attitude of the Hindu Mahasabha were important reasons for the conflict between Hindus and Muslims. ${ }^{213}$

By 1932, a difficult social and political situation existed. The colonial government continued to follow strict financial policies and wanted to preserve separate electorates in order to pacify the Muslim community. At the same time, the Civil Disobedience movements failed

\footnotetext{
${ }^{212}$ See Kaura, Muslims and Indian Nationalism: The Emergence of the Demand for India's Partition 1928-1940, 5964; See Sarkar, Modern India 1885-1947, 257 \& 284-5. Although the first phase of the Civil Disobedience movement was successful, the successors of Irwin followed strict measures that increased India's economic problems. The new Tory secretary of state, Samuel Hoare, increased cotton duty from 20 to $25 \%$. At the second round-table conference in 1931, British businessman Benthall, wanted to safeguard foreign investments in India. The British wanted to return to 'Simonism.' Most importantly, they continued to push for separate electorates as a method to pacify Muslims. Gandhi agreed to accept Muslim demands provided they supported purna swaraj. Muslims rejected Gandhi's condition. Also the Hindu Mahasabha did not support Gandhi. Even after the second round-table conference there was a deadlock over the Hindu-Muslim issue. Jinnah's Presidential Address, $1^{\text {st }}$ series (1938).

${ }^{213}$ Editorial, The Watan, Report on Newspapers and Periodicals in Bengal, March 19, 1932. See Chatterjee, Bengal Divided: Hindu communalism and partition, 1932-1947, 28-33; See Kaura, Muslims and Indian Nationalism: The Emergence of the Demand for India's Partition 1928-1940, 86-95.
} 
due to the lack of political participation and leadership. Even Gandhi was unable to solve the Hindu-Muslim issue. There were riots in Chittagong, Dhaka, and Kishorganj. Hindus and Sikhs requested the government to revise the Communal Award. Historians have argued that the Communal Award was used by the government to exploit the differences between the two communities. It rejected the demands of the Indians on political issues related to the transfer of power from the British Parliament to the Indian people. ${ }^{214}$

In this social milieu, the Muslim leaders wanted the government to increase grants for Muslim education. The government responded to this demand by appointing a committee in 1934 that supervised the progress of Muslim education. The report of the committee indicated that in 1932 only 13 percent of the total Muslim population studied in arts colleges, as compared to fourteen percent in 1927. Fewer Muslims were noticed in commercial, engineering, and medical schools. The number of Muslim students increased in primary schools but it never improved beyond the lowest stage. For example, between 1931 and 1932, 35 out of 100 Hindu boys reached the third and fourth grade, whereas only 14 out of 100 Muslim boys reached the same level. A large number of Muslim boys dropped out of schools before completing the primary courses and relapsed into illiteracy. There were rarely any Muslim students in engineering, medical, and industrial schools. The annual report of the Dhaka University for the years 1932 and 1933 showed a decrease in the number of students pursuing degrees in arts and sciences. The situation slightly improved between 1933 and 1934, but the overall condition of Muslim students remained the same. The government continued to decrease funds for Muslim education and students dropped out of secondary and primary schools. Muslim students failed to

\footnotetext{
${ }^{214}$ Ibid. The Bengal Legislative Assembly Council Proceedings, 39, “Communal Award," August 23, 1932. Suranjan Das, Communal Riots in Bengal 1905 -1947 (New Delhi: Oxford University Press, 1991) 108-10 Editorial, The Masik Mohammadi, , Report on Newspapers and Periodicals in Bengal, March 19, 1932
} 
avail themselves of the benefits of university education. The committee suggested that Muslims felt that the colonial government did not help them adequately, and the education system was unaffordable for poor Muslims. ${ }^{215}$

The committee constantly emphasized that a definite number of seats had to be reserved for Muslims in schools, colleges, ministry, and administration. They recommended the appointment of a Muslim as the head of the Islamic Studies Department at the Dhaka University and fifty percent reservation on all selection committees. Muslims had to be appointed as teachers and the number of free studentships for Muslim students had to be fixed at twenty percent of the total school population. Finally, they wanted maktabs to be considered as primary and not segregated schools, which included both Muslims and non-Muslims, and provided religious and secular instruction. ${ }^{216}$

Following the recommendations of the committee, the Muslim members of the Bengal Legislature passed a resolution that Muslim inspectors had to be appointed for the improvement of Muslim education in all divisions of the presidency. Recruitments had to be made on the basis of the proportion of population strength. Despite several resolutions, qualified Muslims were rarely appointed to various positions. Governing bodies of colleges were reluctant to employ qualified Muslims. There was no dearth of qualified Muslims, but laws were never properly implemented to suit the needs of the community. ${ }^{217}$

\footnotetext{
${ }^{215}$ WBSA, Government of Bengal, Education Department, Report of the Committee to advice on the policy of advancing Muslim education in Bengal, March 1935, Proceedings No: 1, File No: Edn 8 R-24(1); BL, Government of Bengal, University of Dhaka, Annual Report for 1932-33, MSS EUR 221/70; BL, Government of Bengal, University of Dhaka, Annual Report for 1934-35, MSS EUR 221/71.

${ }^{216}$ WBSA, Government of Bengal, Education Department, Report of the Committee to advice on the policy of advancing Muslim education in Bengal, March 1935, Proceedings No: 1, File No: Edn 8 R-24(1).

${ }^{217}$ Ibid.
} 
Evidence indicates that time and again the Bengal Education Department suffered from financial crises. Strict economic policies affected the overall progress of the community. Even after the establishment of separate schools, there was no financial support from the government. At the same time, both Hindu and Muslim leaders used sectional slogans to gather support. Hindus opposed the appointment of maulvis in high schools, and Muslims considered the Congress to be a Hindu organization. The Congress propaganda of a free India did not necessarily mean a secular India, and mullahs or Muslim clerics through their writings and speeches, divided India along religious lines. Grievances over limited financial support and jobs strengthened the demand for separate educational institutions. ${ }^{218}$

Students also expressed their concerns over the growing communal tension between the two communities. Muslim and Hindu students wanted to unite the two communities. Aziz-ud-din Ahmed and Matindra Chandra Bardhan in the articles, "Mahomedan Education in Bengal," and "Indian Nationalism" argued that Muslims failed to progress because they were unable to adjust to the Western system of education. They argued that education policies favored Hindus over Muslims. The community did not receive proper help from the government. Both Ahmed and Bardhan opposed the idea of separate schools for Muslims. Separate schools did not bring about unity between the two communities. There were economic, linguistic, and political differences, but communalism was the main problem. It was essential to have schools that included both Hindus and Muslims. The discriminatory approach of the government and the failure to adjust to the liberal European system of education were the major reasons for Muslim backwardness. The

\footnotetext{
${ }^{218}$ See Shah, In Search of an Identity: Bengali Muslims 1880-1940, 106-7\& 218-9; See Sarkar, Modern India 18851947, 233-7; Editorial, Amrita Bazar Patrika, December 22, 1931, Report on Newspapers and Periodicals in Bengal, 1 of 1932; Editorial, Ananda Bazar Patrika, Report on Newspapers and Periodicals in Bengal, December 18, 1931. WBSA, Government of Bengal, Education Department, Report of the Committee to advice on the policy of advancing Muslim education in Bengal, March 1935, Proceedings No: 1, File No: Edn 8 R-24(1); BL, Government of Bengal, Notes on Muslim Education submitted to the Education Committee, June 1929, MSS EUR 221/52 (a) and (b).
} 
educational and economic disparities between the two communities strengthened communal consciousness. Colonial education policies created a situation that forced the two communities to realize that their goals and aspirations were different. These differences created a rift between Hindus and Muslims and were crucial for the rise of communal tension. ${ }^{219}$

After the failure of the Civil Disobedience movements, the Congress with the support of the Indian capitalists, wanted to contest the legislative assembly elections in several provinces. This period also saw the rise of the Communist Party, which strongly opposed the Indian capitalists. In these circumstances, Hindu and Muslim groups were unable to reach a unified vision for a free India. The political leaders demanded greater benefits and revivalist groups gave communal color to political issues, such as the slaughter of cows and playing of music in front of mosques. Dainik Basumati, Amrita Bazaar Patrika, and Ananda Bazaar Patrika blamed Muslims for their backwardness. Similarly, Dainik Soltan, and Islam Procharak argued that Hindus opposed the development of the Muslim community. This animosity created problems for Muslim education. Muslims demanded reservation of seats in educational institutions, government jobs, and legislative assemblies. They considered these concessions as part of a method to improve their position. The policies introduced by the government did not give Muslims proper opportunity for advancement. Muslim leaders constantly demanded greater funds, but neither the government nor the elected ministers properly implemented education policies to benefit the Muslim community.

The political turmoil and debates over reservation of seats and separate educational institutions continued till the end of colonial rule. Fazlul Huq urged Muslims to end the

\footnotetext{
${ }^{219}$ BL, Government of Bengal, Collection of Sir Philip Hartog, Dacca University Journals, February 1925, MSS EUR E221/136
} 
communal strife and jealousy, as India was on the threshold of constitutional changes. However, Jinnah by the middle of the 1930s was extremely vocal in his demand for the creation of Pakistan. He wanted to safeguard the rights of Muslim minorities from the Hindu Mahasabha, Arya Samajists, and the Congress. The colonial government at the same time introduced the India Act of 1935 that replaced diarchy in the provinces with responsible governments. But, the colonial governors still retained discretionary powers. Limited opportunities offered by the colonial state restricted the prosperity and progress of the Bengali intelligentsia. ${ }^{220}$

\section{Conclusion}

In the 1920s and 1930s we see a significant shift in colonial education policies. Persian and Arabic was no more considered important and the reformed madrassah policy replaced Persian with English in the madrassahs and maktabs. By the 1920s and 1930s vernacular languages no longer received state support. The Dhaka University had an Islamic Studies Department but it had to secure support from private sources. For example, the Government of Bengal demanded a grant of 4181,000 rupees from the Government of India. However, the Government of India decided to provide a grant of 3141,000 rupees. The Government of India decided to curtain provincial expenditure after World War I. Similarly, the Government of India refused to provide a grant of 1090,000 rupees for the establishment of the Calcutta Islamia College in 1922. Moreover, the residential system of education imposed by the colonial rulers deprived the masses of education, and brought about uneven development in society.

${ }^{220}$ See Shah, In Search of an Identity: Bengali Muslims 1880-1940, 106-7. 
Muslims masses did not progress as expected, and their illiteracy was used by Hindu and Muslim leaders to mobilize the masses against each other. ${ }^{221}$

Following the financial crisis, the introduction of separate educational institutions and electorates complicated the social and political situation. For example, the Dhaka University was established to improve Muslim education in East Bengal, but it suffered from financial crises as the Government of India was unwilling to sanction grants. Moreover, Hindus held dominant position in the administration of the university and they were unwilling to give up their position. At the same time, Muslims were afraid of Hindu domination after colonial rule. The national movement directed against colonial rule impoverished the masses. In such a condition, Muslims supported the idea of separate electorates and educational institutions. However, some Muslims preferred separate schools, as it allowed them to maintain their Islamic culture and tradition. The colonial government believed that separate educational institutions were the best solution to the communal problem. In reality, separate schools for Muslims only intensified the communal division. It forced Muslims to think that their position in the society, could only improve if they attended these schools. It can be argued that colonialism and the national movement played an important role in the emergence of communalism, and education was the sector that allowed these differences to be further radicalized. ${ }^{222}$

The debates of the Bengal Legislature and newspaper reports severely criticized the colonial government for reducing grants. Both Hindu and Muslim leaders demanded privileges and benefits for their communities. Newspapers often accused each other of spreading communal hatred. Unfortunately, most of the debates and newspaper reports overlooked the problems

${ }^{221}$ WBSA, Government of Bengal, Education Department, Proceedings of the Government of Bengal, March 1935, 8-R-24 (1) of 1934.

${ }^{222}$ Rakesh Batabyal, Communalism in Bengal, From Famine to Noakhali 1943-47 (New Delhi: Sage Publications India Pvt Ltd, 2005), 67-9. 
associated with the implementation of the reforms. The local agencies responsible for implementing the reforms discriminated against Muslims. There was a huge gap between formulation and implementation of the reforms. The government introduced several policies but never paid much attention as to whether the policies really improved the position of the masses.

Policies introduced by the colonial government with the support of the Indian bureaucracy only alienated Muslims against Hindus, as not enough money was allocated for the purpose of education. Education was one of the domains that allowed these grievances to be politicized. Educational reforms introduced by the colonial government did not suit the needs of the province. Initially, with the beginning of colonial rule, Muslims stayed away from Western education but later on endorsed it to improve their social and economic status. However, to a great extent they were unable to adjust to the secular Western system of learning. This form of education was expensive and always at crossroads with their religious views. A vast majority of the Muslim intelligentsia who believed that colonial education policies would improve their situation, turned against colonial rule, as the policies failed to achieve their goals. Grievances over educational reforms and communalism strengthened educational separateness. 
Progress made by Muslims in education as compared to Hindus from 1926 to 1932

\begin{tabular}{|c|c|c|c|c|}
\hline \multicolumn{5}{|c|}{ Boys } \\
\hline \multirow{2}{*}{ Level of Education } & \multicolumn{2}{|c|}{ Hindus } & \multicolumn{2}{|c|}{ Muslims } \\
\hline & $1926-1927$ & 1931-1932 & 1926-1927 & $1931-32$ \\
\hline $\begin{array}{l}\text { University Education (Arts } \\
\text { Colleges) }\end{array}$ & 84.3 & 84.2 & 14.3 & 13.7 \\
\hline Professional Colleges & 84.0 & 84.0 & 14.1 & 13.1 \\
\hline $\begin{array}{c}\text { School Education (Total for } \\
\text { primary and secondary } \\
\text { education) }\end{array}$ & 52.1 & 48.3 & 46.7 & 49.9 \\
\hline \multicolumn{5}{|c|}{ Girls } \\
\hline $\begin{array}{c}\text { University Education (Arts } \\
\text { Colleges) }\end{array}$ & 56.0 & 78.2 & 1.5 & 1.1 \\
\hline Professional Colleges & 12.7 & -24.1 & - & - \\
\hline $\begin{array}{c}\text { School Education (Total for } \\
\text { primary and secondary } \\
\text { education) }\end{array}$ & 43.8 & 41.8 & 53.3 & 55.7 \\
\hline
\end{tabular}

(Source: West Bengal State Archives, Government of Bengal, Education Department, Proceedings of the Government of Bengal, 1935, Proceedings No 1, File No: 8-R-24 (1) of 1934) 


\section{Chapter 6}

Towards Independence: Muslim education during the final stages of colonial rule, 1935-1947

\section{Introduction}

Historians have argued that education and employment were crucial for the growth of communalism in Bengal. Under colonial rule these two elements determined social mobility and "became the sites of contestation between two communities. In fact they became instrumental in the formation of a sense of community." 223 Colonial education policies were a crucial factor that led to the emergence of separate nations by strengthening separate communal identities. The previous two chapters evaluated the crucial status of Muslim education during the political crisis of the twentieth century and illustrated the problems associated with the implementation of reforms. The absence of an adequate educational infrastructure coincided with shrinking job opportunities and this stimulated conflicts between Hindus and Muslims. The Congress was unable to develop and implement secular programs and this helped the Muslim League to develop as a mass organization after World War I. Even the Communist Party of India was unable to control caste oppression and religious intolerance. In this period of political turmoil Hindu and Muslim elites successfully mobilized rural and urban masses against each other. ${ }^{224}$

This chapter will evaluate the status of Muslim education towards the end of colonial rule and show how policies were constantly affected by the high politics of the period. The India Act of 1935, the elections of 1937, the Second World War, and the Quit India Movement of 1942, further strengthened the separatist ideology of the Muslim leadership. In other words, this chapter successfully combines the role of colonial education policies and the Bengali middle classes (both Hindus and Muslims) to show how they acted as crucial factors in the birth of

${ }^{223}$ See Batabyal, Communalism in Bengal, From Famine to Noakhali 1943-47, 69.

${ }^{224}$ Sumit Sarkar, Popular Movements and Middle Class Leadership in Late Colonial India: Perspectives and Problems of a History From Below (Calcutta: K.P.Bagchi ,1983), 57-8. 
separate nations. However, at the beginning of this chapter, I will briefly discuss the consequences of the Bengal Primary Education Act of 1930. Both Hindu and Muslim legislative council members such as Rai Bahadur Satyendra Kemar Das, P. Banerji and Maulvi Abdul Quaseem accused the government of neglecting nation building programs. For example, primary records indicate that the Government of India claimed to have awarded grants for the establishment of schools in rural areas but in many areas of East Bengal, primary schools were still not established due to lack of financial assistance. The last chapter of the dissertation will also analyze the contributions of Fazlul Huq to Muslim education and show how the efforts of Muslim intellectuals failed in the wake of war, power struggle, and the Pakistan plan. ${ }^{225}$

\section{The Political Crisis of the late 1930s and the status of Muslim Education}

\section{A) The Background Story}

The Depression of the 1930s badly affected India. The value of Indian exports declined from 311 crore rupees in 1929-1930 to 132 crore in 1932-33. Ties between the Indian bourgeoisie and the colonial government weakened and the Congress established itself as the most important nationalist organization. The Congress also secured the support of the Indian industrialists and rich landlords, which resulted in some industrial growth. Additionally, with the increase in population from 306 million in 1921 to 338 million in 1931, economic crisis, and poverty forced parents to discontinue their children's education. Both Hindu and Muslim members of the Bengal legislative council accused the Bengal Government for neglecting primary education. Maulvi Abdul Kaseem argued that the Primary Education Act was implemented after a good deal of discussions but there was no improvement in the condition of

\footnotetext{
${ }^{225}$ India. The Bengal Legislative Assembly Council Proceedings, Central Discussion on the Budget (Calcutta: GPO, 1935)
} 
primary education. The Bengal Government proposed to introduce free primary education in four districts of the province but even after one year the plan was not properly implemented. Only four education boards were formed and the pathsalas were completely neglected. He suggested that it was important to improve primary education before college education. Similarly, Maulvi Abdul Karim indicated that the literacy rate improved from three percent in 1881 to only 8.5 percent in 1931. Prince George V sanctioned 5000,000 rupees for education, of which only 24, 00000 was spent on primary education. Following Kassem and Karim, Begum Hamida Momin argued that not just men but women also demanded free and compulsory education. Financial crisis continued even after implementation of the Bengal Primary Education Act. ${ }^{226}$

Along with Muslims, Hindu intellectuals such as P. Banerji, Sarat Chandra Mitra, and Rai Bahadur Satyaendra Kumar Das severely criticized the government for neglecting primary education. The government spent excessively on military and police but overlooked important sectors including, education and public health. The government employees received huge salaries whereas rest of the province was deprived of basic needs. People demanded proper primary education but the government did not allocate sufficient funds for the pressing needs of the province. The Education Department had very few staff in comparison to other departments. For example, there were just 64,000 primary schools and 267 sub inspectors. Unanimously both Hindus and Muslim elites believed that the government allocated very little money for primary education. Even secondary education did not suit the needs of the people. Most of the funds were used to improve higher education. They indicated that the education system had to be revised;

\footnotetext{
${ }^{226}$ India. The Bengal Legislative Assembly Council Proceedings, Central Discussion on the Budget, (Calcutta: GPO, 1935), 122-202; See Sarkar, Modern India 1885-1947, 258-61 \& 336-8
} 
provision had to be made for struggling Muslim students, who failed to secure jobs as faculty in government colleges. $^{227}$

The legislative council debates reflect how the Bengali elite turned against the government. This indeed was a real shift from the late nineteenth century when the intelligentsia to a great extent was cooperating with colonial rule for the introduction of primary, secondary, and higher education. The fact that only 8.5 percent of the total Bengali population was educated in 1931 reflected the growing grievances of the people. In 1934, the government decreased a grant to non-governmental colleges from one lakh 29,000 rupees to 45,000. Colonial exploitation impoverished the Bengal countryside, industries suffered, and primary education was ignored. In this situation the government decided to increase taxes in order to improve the condition of primary education. This decision to increase taxes further angered the two communities, and by the middle of the 1930s both the Hindu and Muslim intelligentsia were extremely vocal against colonial oppression. ${ }^{228}$

However, Mr. W.B.G Laidlaw, a member of the Bengal legislative council, indicated that taxes had to be increased in order to improve the lives of people. He suggested that the Bengal budget allocated enough money for education and the surplus revenue was used to meet the requirements of the province during periods of droughts and starvation. In this situation nonofficial agencies such as Banibhavan, Narisiksha Pratisthan, Saroj Nalini Dutta Association, and Anjuman-i-Khawatin Islam played important roles in the spread of primary education among women. The Bangiya Mussalman Sikha Samity (Bengali Muslim Education Society) educated Muslims, preserved the old Muslim Bengali literature and catered to the social needs of Bengali

\footnotetext{
${ }^{227}$ India. The Bengal Legislative Assembly Council Proceedings, Central Discussion on the Budget, (Calcutta: GPO, 1935), 122-202.

${ }^{228}$ Ibid.
} 
Muslims. These anjumans provided a new direction to the Muslim community and also developed a parallel culture that preserved Islamic traits. They glorified the socio-cultural exclusiveness of the Bengali Muslims. For example the Dhaka Sahitya Samaj (Dhaka Literary Society) indicated that Islam was superior to Hinduism. In other words, towards the end of colonial rule, the government completely depended on private organizations in the spread of primary education. At the same time, these organizations Islamized the outlook and the attitude of the rural masses and prepared them for political purposes. They anjumans advocated the need for a separate homeland, as a method to maintain the cultural freedom of the Muslims. It becomes clear that according to Bengali intellectuals, the declining support from the Bengal Government and the Government of India reduced their faith in the colonial rule. Limited opportunities and resources within the colonial structure paved the ground for the rise of separatist ideology. Muslim leaders strongly felt the need for a separate nation and to the British this was the only available solution. ${ }^{229}$

Along with education policies, the political situation also became complicated after the failure of the Civil Disobedience movements. The Communal Award of 1932 made it clear that Muslim goals were different from Hindus. Muslims felt that some of the benefits granted by the colonial government helped in the advancement of the community. But Hindus opposed the award. Moreover, after the award, Hindu bhadraloks showed interest and tried to control local affairs. The communal provisions of the Act of 1935 did not apply to local district boards, school boards and committees where elections were still held based on joint electorates without any reservation of seats. As the role of Hindu bhadraloks was limited by the Communal Award, they

\footnotetext{
${ }^{229}$ See Ahmed, The Bengal Muslims 1871-1906: A Quest for Identity, 133-70; See De, Bengal Muslims in Search of Social Identity, 47-82.
} 
continued to exercise greater influence over local politics. Bhadraloks mostly targeted scheduled caste Hindus and those living in mufassils. There was a rise of a self-conscious Hindu political community in Bengal. But the Hindu power was also challenged by the increasing Muslim influence in the localities especially in East Bengal. In this communally polarized circumstance, the loss of control over educational institutions was opposed by Hindu bhadraloks who considered education their cultural and intellectual property. Moreover, major financial decisions related to education were still taken by the British Governor of Bengal. ${ }^{230}$

\section{B) The India Act of 1935 and Muslim Education (1935-1937)}

The Report of the Director of Public Instruction for 1935 showed that immediately after the implementation of the Act of 1935, the Government of India gave generous grants to various provinces for rural reconstruction. The Bengal Education Department received a grant of ten lakh rupees for the improvement of primary and secondary education. Despite this grant, there was an overall decrease in the number of educational institutions, as the weaker institutions were amalgamated with the reputed ones. For example, the number of primary schools decreased from 64,309 in $1934-35$ to 62,150 in $1935-36$. At the same time, the government realized that sufficient money was not available for the real improvement of education. Trained teachers and proper infrastructure were not available that would induce parents to send their children to

\footnotetext{
${ }^{230}$ See Sarkar, Modern India 1885-1947, 258-61 \& 336-8. The 1935 Act replaced diarchy in the provinces with responsible government. It increased the electorate from 6.5 million to 30 million. The governors of the provinces retained majority of the powers. The elected ministers were allowed to express their opinion of several issues but in most cases they were rejected. The governors had the right to take over the administration for an indefinite period of time; See Sen, Muslim Politics in Bengal 1937-1947, 68-72; See Chatterjee, Bengal Divided: Hindu Communalism and Partition 1932-1947, 204-9.
} 
school. Despite this condition, the government wanted to revive religious education at the primary level, as there were more Muslim than Hindu students at the primary level. ${ }^{231}$

The condition of secondary and college education was also in decline. There was a ten percent reduction in the grants assigned to secondary schools and colleges. Secondary schools also witnessed a fall in their income from donations and subscriptions. In the case of higher education, the entire province just had ten government colleges with 3,969 students in 1935 . In 1934 these ten colleges had 3,855 students. The number of students slightly increased but the number of colleges remained the same. The report indicated that a decrease in financial assistance from the government affected the efficiency of the education system. ${ }^{232}$

In the case of Muslim education, Professor A.F.Rahman was appointed as the first Muslim Vice-Chancellor of the Dhaka University. The number of maktabs decreased from 26,649 to 26,071 . This decrease was mainly because of the elimination and amalgamation of schools. Similarly, the percentage of Muslim students in all forms of schools decreased from 51.9 percent in 1934 to 51.1 percent in 1935 . The report also indicated that Muslims continued to enjoy special privileges such as reservation in government and aided schools and special scholarships and stipends. $^{233}$

The privileges provided by the government were mostly enjoyed by the Muslim middle class who wanted to revive the Islamic culture. However, government educational institutions were dominated by Hindus and Muslims found it difficult to continue their education. Between 1935 and 1937, right wing Hindu groups such as the Hindu Mahasabha opposed the privileges

\footnotetext{
${ }^{231}$ British Library (Hereafter BL), Government of Bengal, Report on Public Instruction in Bengal 1935-36, IOR V/24/989.

${ }^{232}$ Ibid.

${ }^{233}$ Ibid.
} 
enjoyed by the Muslim middle class. To counter Hindu domination, the Nawab of Dhaka warned Muslim students from middle class families against the de-Moslemising effects of the university textbooks. They demanded that textbooks had to address Islamic culture and Urdu had to be made the second language for all Muslim students. They also demanded the introduction of Muslim debating clubs for imparting Islamic culture and ideas among Muslim students. Historians have argued that reformers, who spoke about cultural synthesis, now favored a separate Muslim homeland. It was becoming clear that after the act of 1935 and the elections of 1937 "Divide and quit" was the most attractive solution available to the British, as they did not want to antagonize the Muslim League, the only loyal group in the subcontinent. ${ }^{234}$

Along with education, Hindu domination was visible in politics as they strengthened their control over the Congress. Gandhi retired from the Congress in 1934 and Nehru was largely criticized for his socialist views. However, despite these tensions, Congress did extremely well in the elections of 1937. In Bengal, the Congress won a total of 47 seats. The Congress membership increased from 3.1 million in 1936 to 4.5 million in 1938. But the Congress could not perform well in the Muslim constituencies of Bengal. Despite the increased membership, the Congress formed the largest opposition in the Bengal legislative assembly. Fazlul Huq was sworn in the as the first premier of Bengal on April 1, 1937. Before the elections the Muslim League and the Krishak Praja Party (KPP) fought as rivals. KPP and the Congress were informal allies. During the elections, the Congress allowed KPP to contest in the Muslim seats. But in early 1937 the two parties failed to reach an agreement on the coalition government. Congress leaders, such as Sarat Bose, Bidhan Chandra Roy, and Kiran Shankar Roy, wanted the release of political prisoners to be the first priority. However, KPP wanted krishak (peasant) welfare. KPP felt that

\footnotetext{
${ }^{234}$ See De, Bengal Muslims in Search of Social Identity, 188-203; Mohammad Sanaullah, A.K. Fazlul Huq: Portrait of a Leader (Bangladesh: Homeland Press and Publication, 1995), 100-1.
} 
the commitment of the ministry to resign over the release of political prisoners would jeopardize peasant welfare. ${ }^{235}$

After the elections, neither the Muslim League nor the KPP could establish themselves as the organization representing the needs of Muslims. Jinnah's influence was gradually decreasing as he lost the confidence of his party. As a result, the league on the other hand accepted the demands of the KPP and agreed to accept Fazlul Huq as the first premier of Bengal. Fazlul Huq in 1937 formed a ministry of eleven ministers. The elections of 1937 brought a large number of rural representatives to the legislative assembly. Some of them were zamindars and others were young politicians born and bred in the mufassils. The assembly had a lot of peasant leaders who wanted peasant welfare. Fazlul Huq was the self proclaimed leader of this coalition between the league and the KPP. He was also the Education Minister of Bengal in $1937 .^{236}$ The next section will examine his role as politician and a visionary in the field of education.

\footnotetext{
${ }^{235}$ See Chatterjee, Bengal Divided: Hindu Communalism and Partition 1932-1947, 103-5. KPP: Muslim politics in Bengal can be divided into three camps. First, the Muslim aristocrats followed by the non-Bengali Muslim community, and finally, the peasants. In 1936, the Nikhil Banga Praja Samiti (All Bengal Workers Association) underwent several changes. The radical elements of this party demanded that lands must be owned by the tillers of the soil. The influence of the radical elements increased and the name of the Krishak Praja Samiti was changed to Krishak Praja Party in April 1936. Fazlul Huq assumed the leadership of the party. See Sanaullah, A.K. Fazlul Huq: Portrait of a Leader, 96-7.

${ }^{236}$ See Sarkar, Modern India 1885-1947, 345-57; See Sen, Muslim Politics in Bengal 1937-1947, 83-95. Historians have argued that the Congress refusal to collaborate with KPP forced Huq to join hands with the League. Huq's ministry included five Hindu and six Muslim members. However, Shamsuddin of KPP was dropped and Musharaff Hussain of the Muslim League was included in his place. The first ministry of Bengal under provincial autonomy was dominated by the Muslim League. The composition of the ministry was opposed by the Congress and KPP. This forced Huq to join the League in the October of 1937.
} 


\section{Fazlul Huq: The Politician and the Educationist}

\section{A) The Politician}

According to historians, Fazlul Huq was a hero, a leader of leaders but was also politically unpredictable. The masses adored him because he tried to liberate them from the Hindu zamindars and the money lending class. The middle class adored him because he provided them with jobs and education. In other words, he appeared to be a charismatic figure. He played an important role in the Partition of Bengal in 1905 carving out a province for Muslims from the backward Muslim hinterland of Bengal and Assam. In 1918 he was the leader of the Proja Movement (movement against the British rule), President of the Muslim League, and the General Secretary of the Indian National Congress. However, his relationship with the Congress ended in 1921, when he failed to identify with the goals of the Congressmen. The Krishak Praja Movement was transformed into a party in 1929 and he was elected the President of the Krishak Praja Party. ${ }^{237}$

Before the elections of 1937, Jinnah in1936 wanted to collaborate with Fazlul Huq for his party's rural base. But Huq wanted to abolish the zamindari system, which was not possible for Jinnah because the National Muslim League was dominated by nawabs, zamindars, and businessmen. In the elections of 1937 none of the parties, Congress, Muslim League or the Krishak Praja Party were in a position to form the Cabinet. The Congress with highest number of seats offered to form a coalition with KPP. But the Congress wanted the British government to release the political prisoners, which was unacceptable to Huq as he felt that it would create a constitutional crisis in the province. Moreover, Huq showed how the Congress inflicted

\footnotetext{
${ }^{237}$ Kazi Ahmed Kamal, A.Z. Fazlul Huq, Suhrawardy, and Maulana Bhashani: An Intimate Study of Politicians and
} Inside Stories (Dhaka: A.H. Development Publishing House, 1970), 1-5. 
oppression on Muslims after the elections of 1937. After winning the elections, the Congress ministers issued orders for the hoisting of the Congress flag in all public institutions, including schools and colleges. They encouraged the study of Hindi, introduced objectionable text-books in Muslim schools, and virtually abandoned Urdu in schools. For example, in Rajpur and Khaira districts Hindus attacked Muslims while they were praying in the mosque. Hindus then burnt Muslim houses, and the police did not take any action against them. In the Central Provinces and Berar, Muslim students in Urdu schools had to celebrate Gandhi's birthday and worship his idol. In government schools in Bengal, Muslim students were required to sing the Bande Mataram in order to remain in schools. Teachers who sympathized with the Muslim League were victimized, and the Congress prohibited the printing of Urdu text-books, which created problems for Urdu medium schools. In this situation, the Muslim League offered Huq to form a Coalition Ministry headed by him. Huq accepted League's offer and aimed to bring Muslims back into political power after two hundred years. Lastly, the Coalition gave high hopes to Muslims both in terms of education and employment. ${ }^{238}$

\section{B) Fazlul Huq as the Education Minister}

All his life Huq endeavored to improve the social status of backward people. He expressed concern over Muslim backwardness and adopted several measures to improve Muslim education, first as an education minister in 1924 and then again from 1937 to 1945. In 1924 he emphasized the study of English and argued that Islam did not oppose Western education. Huq believed that the annulment of the Partition of Bengal brought an abrupt end to the educational progress of East Bengal and the province needed special consideration. He also warned Muslim

\footnotetext{
${ }^{238}$ See Sanaullah, A.K. Fazlul Huq: Portrait of a Leader, 96-103; A.K. Fazlul Huq, Muslim Sufferings under Congress rule, 1939.
} 
students not to boycott English education and molded their opinion towards Western education. His efforts to improve Muslim education bore fruit when the British Government softened their attitude towards the educational requirements of Muslims. The Islamia College was established in Calcutta, which was similar to the Hindu College. In addition to the Baker and Elliot hostels, the Bengal Government established the Taylor and Carmichael hostels to accommodate Muslim students studying at the Presidency and other colleges of Calcutta. Moreover, his education policies played a crucial role in the success of KPP. He emphasized that masses needed to be educated, which distinguished the KPP from the Congress and the League. ${ }^{239}$

After the elections of 1937, Huq's efforts induced the Government of Bengal to start adult education centers in rural areas and introduce matriculation examinations in high schools from 1940. Education records indicate that after the introduction of provincial autonomy, the number of students in all forms of educational institutions increased despite the policy of concentration, where weaker schools were abolished or merged with the more powerful schools. For example, the total number of students in all form of institutions increased from 3075,272 in 1934-1935 to 3146, 291 in 1935-36 and finally to 3380, 660 in 1938. The number of Muslim students in all forms of educational institutions increased from 1598,675 in $1934-35$ to 1829,332 in 1938-39. The total expenditure on primary education increased from 6662,424 rupees in 193435 to 8610,553 in $1938-1939$. Similarly in the case of college education the expenditure increased from 3778,218 to 3841,803 rupees. Moreover, Huq played an important role in

${ }^{239}$ See Sanaullah, A.K. Fazlul Huq: Portrait of a Leader, 191-210. 
increasing enrollment at the Dhaka University. The total number of students at the Dhaka University increased from 1,042 in $1934-35$ to 1,471 in $1939 .{ }^{240}$

During Huq's tenure as the education minister, the academic reputation of the Dhaka University was well maintained, and students and faculty published papers in recognized journals. Additional scholarships were introduced for students of the Islamic Studies Department. Moreover, he made special provision for two state scholarships from the Lytton and Mohsin Funds for Muslim students intending to study at an overseas institution. Muslim students also had the option to compete for other overseas scholarships. Huq believed the attitude of the colonial government was responsible for Muslim backwardness and he made sincere efforts to improve their social status. Huq also promoted communal unity at the Dhaka University by rewarding a Hindu and a Muslim student with gold medals. Maulvi Osman Ali, the editor of the Bengali monthly, Subuj Bangla (Green Bengal), awarded gold medals to the best essays written by a Hindu student on any topic of Islamic interest, and to a Muslim student on any topic of Hindu interest. Although provincial autonomy increased the literacy rate in the province, the government failed to provide adequate jobs, which basically increased the grievances of both communities. A few attempts to promote communal harmony were over shadowed by political tension and financial problems. Schools and colleges had to follow a strict set of rules in order to receive grants. There was a ten percent reduction in grants to colleges from the Bengal Government and this created financial problems for many colleges. Despite an increase in

\footnotetext{
${ }^{240}$ BL, Government of Bengal, Report on Public Instruction in Bengal 1934-35, 1936-37, 1938-1939, IOR $\mathrm{V} / 24 / 989$.
} 
enrollment in primary schools, unemployment, political turmoil, and financial crisis aggravated the communal situation of the province. ${ }^{241}$

Throughout the twentieth century financial crisis was a constant problem, the government reduced financial aid, and this affected the efficiency of schools and colleges. Primary education was suffering and whatever money the government allocated for education was used for improving higher education. The entire province had just 143 maktabs and six muallim schools (training schools for maulvis). At the same time, after the elections of 1937 the political situation was extremely unstable. The Hindus of Bengal believed that they made the maximum contribution towards the development of Bengal. Ashutosh Bagchi, one of the contributors to Sanibarer Chithi, identified India with Hinduism. He believed that Muslims did not consider India as their motherland. In response to Hindu chauvinism, Bengali Muslims preferred a separate identity and eventually a separate homeland. Mujibur Rahman, a leading journalist of the time, in his book Pakistan argued that a separate homeland provided freedom to Muslims from Hindu domination. Political turmoil along with discrimination in the field of education was giving shape to the idea of Pakistan. ${ }^{242}$

Huq made sincere efforts to improve Muslim education and also promote communal harmony. He was in favor of Muslim education, as it was the only method to succeed. During his tenure, grants-in-aid were extended to senior madrassahs. Huq's education policies reflected his ideology to improve the educational status of the masses. However, Huq's government nominated more Muslims in local bodies than Hindus. For example in Rangpur, Muslims held majority of the positions in local bodies, which led to communal riots. This policy

\footnotetext{
${ }^{241}$ BL, Government of Bengal, University of Dhaka Annual Report, 1937-38, MSS EUR 221/75;

${ }^{242}$ See De, Bengal Muslims in Search of Social Identity, 188-203.
} 
of nominating more Muslims to local bodies and School Boards increased the resentment among the Congress and the Hindu Mahasabha. Although problems existed he wanted in terms of financial support, he made sincere efforts to improve education in general. The next section will examine his education policies during the period of crisis from1938-1942. ${ }^{243}$

\section{The crisis continues (1938-1942)}

The elections of 1937 strengthened Fazlul Huq's control over the Muslims of Bengal and it also established the league, as the only Muslim political party in Bengal. At the same time, Fazlul's Huq's ministry faced tough opposition from the Congress because of its controversial education and land revenue policies, especially for the support extended to the Secondary Education Bill of 1940 and the effort to reserve seats for Muslims in government educational institutions and jobs. The Congress accused the ministry of increasing taxation on primary education, which affected the overall progress of the province. Similarly, Jinnah accused the Congress of being a Hindu organization at the All India Muslim League session in 1938. According to Jinnah, the Congress wanted to dominate the Muslims and Gandhi wanted to revive Hinduism and establish a Hindu Raj in India. In response to this attitude, Jinnah urged Muslims not to form an alliance either with the Congress or the British. He opposed the federal scheme proposed by the Congress and believed that the federation would actually destroy Muslim culture. Jinnah requested Muslims in the Congress camp to join the league for the benefit of the community. Separatist policies continued to strengthen the league's position in the ministry. The

\footnotetext{
${ }^{243}$ BL, Government of Bengal, Report on Public Instruction in Bengal 1934-35, 1936-37, 1938-1939, IOR V/24/989; See Chatterjee, Bengal Divided: Hindu Communalism and Partition 1932-1947, 207-9.
} 
league organized local branches of the party and depended on Islamic solidarity and government support. $^{244}$

In this chaotic situation, Muslim members of the legislative council demanded more funds for Muslim education. Leaders, including Khan Bahadur Saiyed Muzzamuddin Ahmed, Humayun Kabir, and Bamkim Chandra Dutta, criticized the Bengal Government for allocating insufficient money for education. They opposed the government expenditure on Arabic and Persian education. They demanded English education, as it was needed to improve the social and economic conditions of the community. Maulvi Mohammad Ibrahim indicated that for the Muslims, there was no alternative scope for progress and that they needed education to improve their social status. Muslim leaders demanded more financial support in the form of scholarships and hostel accommodation for Muslim students. ${ }^{245}$

Similarly, Fazlul Huq believed that efficient secondary education would improve the general condition of the Muslim community. Secondary education received a lot of attention from the ministry. They wanted to completely reorganize secondary education. A revised curriculum was introduced in several high schools and provision was made for instruction through the mother tongue. The first matriculation examination was scheduled to be held in 1940 through the vernacular medium. Commercial firms donated money to Calcutta and Dhaka universities for conducting research that benefited these firms. In general, reforms for improving secondary education attracted a lot of attention. ${ }^{246}$

\footnotetext{
${ }^{244}$ See Sen, Muslim Politics in Bengal 1937-1947, 100-5 \&124-5; See Sarkar, Modern India 1885-1947, 354-5 Ayesha Jalal, The Sole Spokesman: Jinnah, the Muslim League and the Demand for Pakistan (Cambridge: Cambridge University Press, 1985), 26-8.

${ }^{245}$ India, The Bengal Legislative Assembly Council Proceedings, (Calcutta: GPO, 1938)

${ }^{246}$ BL, Government of Bengal, Report of the Director of Public Instruction for Bengal, 1934-35, 1935-36, 19381939, IOR V/11/806.
} 
Grants were also sanctioned for the improvement of Muslim education. Lady Brabourne College was established in Calcutta for Muslim women's education. Three new departments were introduced at Dhaka University and a second Muslim Hall was proposed for Muslim students. The Hoogly Madrassah was raised to the status of an Islamic Intermediate College. Despite this effort to improve Muslim education, discrimination still existed. For example, Presidency College had 951 Hindu students and only 198 Muslim students. A similar situation existed in Chittagong, Hoogly, and Krishnagar colleges. Even in the case of women's education, there was a disparity in terms of Hindu and Muslim students. Bethune College had 260 Hindu and 29 Muslim female students. Kamrunessa Girls' Intermediate College at Dhaka had 160 Hindu and only five Muslim female students. Most of these institutions did not have provisions for instruction in Arabic, Persian, and Urdu. It was clear that inequality still existed in education and employment and Fazlul's Huq's ministry decided that 50 percent of the seats would be reserved for Muslims in schools, colleges, and jobs. The Congress disapproved these policies and accused the ministry of adopting anti-Hindu policies. ${ }^{247}$

As the political crisis continued, India was drawn into the Second World War on September 3, 1939. There were approximately three million men recruited by the British Indian Army to fight in the Second World War. Bengal contributed 125,000, of which most were recruited from the districts of East Bengal. This recruitment amounted to around 0.25 million in the early in 1942. The price of food grains increased, and in Calcutta most of the industries produced for the army. The Indian industrialists' prospered but mass sufferings increased. There

\footnotetext{
${ }^{247}$ See Sen, Muslim Politics in Bengal 1937-1947, 112-8; Jinnah wanted the Congress to withdraw all the opposition to the Communal Award. He also demanded religious and cultural freedom for Muslims, reservation on all state services, separate electorates, and abolition of the Bande Mataram. However, Nehru did not consider the demands of Jinnah and was more eager to frame the future constitution of independent India. This attitude repelled Jinnah and many other Muslim leaders such as Syed Mahmud and Maulana Azad; BL, Government of Bengal, Report of the Director of Public Instruction for Bengal, 1934-35, 1935-36, 1938-1939, IOR V/11/806; See Kaura, Muslims and Indian Nationalism: The Emergence of the Demand for India's Partition 1928-1940, 109-35.
} 
was widespread corruption, inflation, and chronic shortage of food grains that culminated in famine. However, by this phase it was clear that the British government was unable to control the social and political situation of the country and that they would retreat very soon. According to historians, this triggered bitter debates between the Congress and the League over the future of the Indian government. ${ }^{248}$

Government records indicate that even during the Second World War and the growing political crisis, there was an increase in the number of students in different types of educational institutions. The Annual Report of the Dhaka University showed that the number of students increased from 1569 in $1939-40$ to 1633 in 1940-41. This was perhaps the largest increase in the number of students at the Dhaka University. Communal riots could not stop students from attending the university. Moreover, even in this period of crisis, Huq sanctioned two lakh rupees for the Adina Fazlul Huq College established in Nawabganj in 1940. This college allowed poor Muslim students to continue their education. At the All India Education Conference in 1940 he criticized the British Government for neglecting higher education. The Bengal Government did not allocate enough money for Muslim education, and it was not possible for the university alone to uplift the educational standard of Muslims. He requested educational institutions to donate money for the improvement of Muslim education. ${ }^{249}$

Historians have argued that Huq improved the enrollment of Muslim students in ordinary colleges. However, the political crises of the early 1940s had an impact on the progress of education. The Dhaka University in 1940 had to postpone exams and the session of the Indian Science Congress. The number of students in the arts faculty increased to 1569 . However, it

\footnotetext{
${ }^{248}$ See Batabyal, Communalism in Bengal, From Famine to Noakhali 1943-47, 78-81.

${ }^{249}$ BL, Government of Bengal, University of Dacca, Annual Report, 1940-41, Mss Eur 221/78.
} 
failed to establish the engineering faculty. But, the situation changed the next year, when riots decreased the number of students from 1,633 to 1,408. Riots and political disturbances hindered academic advancement. There were conflicts among student groups inside the university campus over the singing of Bande Mataram. It affected not just students' lives but also, the finances of the university. The government did not sanction money for the teaching of Geography and Statistics and refused to appoint professors. At the same time, the Second World War forced the Government of Bengal to take over the university building for war purposes, and this made it difficult for the university to accommodate teachers and students. Education was greatly affected by the war and contemporary political changes. ${ }^{250}$

Educational reforms further complicated the relationship between the two communities, especially over the Secondary Education Bill of 1940. Huq introduced the bill on August $21^{\text {st }}$ 1940. The bill sought to remove primary education from the control of the Calcutta University and establish a secondary education board. He wanted to include Muslims in the board, as a method to improve their position in the society. The bill aimed to improve, control, and regulate secondary education in Bengal. It intended to establish a secondary board, consisting of fiftythree members. Most of the members were either nominated or ex-officio. The elected members were selected from the separate Hindu and Muslim electorates. Members of the Congress, Hindu Mahasabha, and Krishak Praja Party opposed it and highlighted that it could lead to communal tension. Huq tried to project the bill as a product of the deliberations of a select committee

\footnotetext{
${ }^{250}$ BL, Government of Bengal, University of Dacca, Annual Report, 1941-42, Mss Eur 221/79; BL, Government of Bengal, University of Dacca Annual Report, 1944-45, Mss Eur 221/80.
} 
established in 1942. He considered opposition to the bill senseless and indicated that it came from the influential section of the community. ${ }^{251}$

However, the bill was not free from criticisms. The students of the Calcutta University opposed the bureaucratic control over education. These protests highlighted the communal nature of the bill, and the ministry considered these oppositions as an attempt by high caste Hindus to retain their monopoly over secondary education. The provision for separate communal electorates heightened the apprehensions of the Hindu middle class. The All Bengal Teachers' Association protested against the bill, and demanded that the government should develop a plan to improve secondary education in the province. The protests against the bill protected and solidified Bengali Hindu culture. The Bengali Hindus indicated the need for a separate Hindu state based on cultural integrity. Shyama Prasad Mukherjee and Kiron Shankar Roy opposed the bill. Mukherjee toured different parts of eastern Bengal and came to the conclusion that Mussalmani Bangla had destroyed the nationalist spirit among Hindu boys. Authors such as Tarashankar Bandopadhyay, at the Probasi Bangla Sahitya Sammelan (Overseas Bengali Literary Meeting) declared that Bengal should be partitioned in order to protect Hindu culture, education, and civilization. Authors, poets, and intellectuals supported the Hindu Andolan (Movement) and the worship of the Bharatmata (Mother India). In other words, the demand for a separate Hindu state remained strong. ${ }^{252}$

However, the Muslim League organized meetings in several parts of the province in support of the bill. In Calcutta, the people of Noakhali passed a resolution supporting the bill. Muslim students also supported the bill. Historians have argued that according to the league, this

\footnotetext{
${ }^{251}$ See Batabyal, Communalism in Bengal, From Famine to Noakhali 1943-47, 139-46.

${ }^{252}$ Ibid. See De, Bengal Muslims in Search of Social Identity, 196-8.
} 
was an opportunity to further their interests. They requested support from Muslims students and pirs (Muslim saints). For example, pir of Sirshina declared that the league was the only organization for Muslims and that it had the support of Jamait-ilama-i-islam. He also wanted an early passage of the bill. The League completely supported the bill, as a method to improve the status of Muslims. ${ }^{253}$

A constant conflict continued between the League and the Congress over the Secondary Education Bill of 1940. In the mean time, the League dominated the ministry and Fazlul Huq was critical of the League ministers and the Bengal Government in his letter to Sir John Herbert, the Governor of Bengal. In his letter he noted that after the India Act of 1935, the permanent officials had all powers but no responsibilities. They ignored the Indian ministers and their powers, and this was encouraged by the Governor of Bengal. The Governor ignored the demands of the people and disregarded the views of the Chief Minister over parliamentary appointments. Indian ministers were transferred without the consent of the Chief Minister. Lady Brabourne College was closed without his consent and Muslims were not appointed to various positions in the Calcutta University. This increased the resentment of Muslims. Herbert, the Governor also opposed the formation of the Progressive Coalition cabinet in 1941, which included two ministers from the schedule caste. Huq wanted the Governor, to reopen the Lady Brabourne College and include four more ministers in the cabinet. Most importantly, he wanted him to be the head of the state and not a mouth piece of the permanent officials. But Herbert forced Huq to resign from his post. Huq rebuked Herbert for violating the laws of the India Act. Herbert made no effort to develop an all-parties cabinet and neglected the food problems of the province. The ministers of the cabinet also neglected the problems of the province. Huq indicated

\footnotetext{
${ }^{253}$ See Batabyal, Communalism in Bengal, From Famine to Noakhali 1943-47, 139-46.
} 
that Bengal was on the verge of bankruptcy and the famine had devastated the province. Autocratic rulers governed the province and provincial autonomy was completely strangled. ${ }^{254}$

In the letter, Huq also criticized the Muslim ministers of the cabinet and the league. After the introduction of provincial autonomy, the British favored the Muslim League and this gave the league an opportunity to oppose the political ascendancy of the Congress. The Muslim ministers of the cabinet were under the control of Jinnah, and he made no effort to stop taxation. Jinnah only wanted members of the Muslim League to be part of the Cabinet. According to Huq, the Act of 1935 did not establish democracy in India but was a warning for the future leaders of India. At the same time, Indians did not protest against the policies of the government, which devastated the country and the province. For example, the government agents deprived rural people of rice. The press in Bengal was also paralyzed. It had been controlled by the ministers, and was unwilling to accept opposition. ${ }^{255}$

Huq felt that the policies followed by the league and the Governor went against the Muslim interests of Bengal. However, his educational reforms increased Muslim representation in government educational institutions and jobs especially at the local level. The reforms helped Muslims to demand their legitimate rights through movements and turn toward the values of liberty, democracy, and good governance. Moreover, as madrassah education was modernized, it changed the outlook of the Muslims. Ulemas embraced English education and Huq himself wanted harmonious growth of Hindus and Muslims. ${ }^{256}$

The period between 1940 and 1942 witnessed several shifts in Muslim politics. Jinnah considered himself as the leader of all India Muslims, and Huq believed that he was the

\footnotetext{
${ }^{254}$ A.K. Fazlul Huq, Bengal Today (Calcutta: Gupta Rahman and Gupta, 1944), 1-24.

${ }^{255}$ Ibid.

${ }^{256}$ See Sanaullah, A.K. Fazlul Huq: Portrait of a Leader, 244-6.
} 
custodian of Bengali Muslims. The Lahore Resolution of 1940 did not explicitly mention Pakistan or Partition but demanded that Muslim majority areas, including eastern and northwestern zones, be considered as independent states. Huq never openly opposed the idea of Pakistan, which he believed protected the rights of Bengali Muslims. This political uncertainty allowed the British to maintain a constitutional deadlock in India. At the same time, Jinnah's demand to include Muslim non-official advisors in the provinces and more seats in the expanded Executive Council were rejected. The colonial government did not surrender to Jinnah's demands. In other words, there was not just political and constitutional deadlock but also a split in the Muslim League. By this point it was clear that leaders were working for personal gains and they were not opposed to the idea of Pakistan. ${ }^{257}$

The social situation became further complicated with the Second World War. Britain was able to solicit support for the war but the Congress leaders were unable to come to a unanimous decision about central leadership. The districts of Noakhali, Tippera, and Chittagong were hit by Japanese bombs followed by massive evacuation, breakdown of communications, and sudden influx of refugees from Burma. There was complete breakdown of civil administration and this forced the leaders of the affected regions for restoration of some sort of order. It was at this point Labor MP Stafford Cripps in 1942 was able to convince the War Cabinet for a post war Dominion Status in India. However, Cripps Mission was filled with ambiguities and after much discussion with the British; Nehru realized that they were not keen to

${ }^{257}$ See Sen, Muslim Politics in Bengal 1937-1947, 133-5. See Sarkar, Modern India 1885-1947, 379-81. 
impart power to the Indians. After the failure of the Cripps Mission, the ground was prepared for the final phase of the partition plan. ${ }^{258}$.

\section{The Last Phase: Partition Politics and Muslim education (1942-47)}

After the Second World War, the British policy towards India changed. Jaya Chatterjee argues that the Cripps Mission was nothing more than a "public relations exercise," which was bound to fail. (Chatterjee, 220) However, after the war, the ambiguous Pakistan plan was becoming important to protect the territories east of Suez. But after the elections of 1945-46, it was difficult for the British to ignore Jinnah and the demands of the league. The Congress did very well in the Hindu majority districts all over India but failed to represent the Muslims. In Bengal, after the elections of 1945-46, the Muslim League was back in power in Bengal. Huseyn Suhrawardy in 1946 formed the ministry and became the new Prime Minister of Bengal. He limited the number of Hindu ministers in his ministry to three of which two were scheduled castes. Suhrawardy's declaration of holiday on Muslim League's Direct Action Day followed by the failure to deal with the civil war further convinced Hindus that a Muslim government would lead to "Pakistanisation of Bengal." Chatterjee argues Partition was not imposed by the Government of India but was a symbiotic relationship between the center and the province, whereby the policymakers responded to the demands of the province. She further argued that the Communal Award and the Poona Pact deprived Hindu bhadraloks of their power and gave power and opportunities to some Muslims. Hindu communal strategies played an important role in mobilizing Hindu masses against Muslims. Chatterjee concludes that bhadralok Hindus

\footnotetext{
${ }^{258}$ See Batabyal, Communalism in Bengal, From Famine to Noakhali 1943-47, 146-7, See Sarkar, Modern India 1885-1947, 387-8.
} 
wanted to prevent the return of Muslim despotism after the British left India. Hence they directed their communalism against fellow Bengali Muslims. ${ }^{259}$

Challenging Chatterjee's views, Batbyal argues that education and employment fostered the growth of communal consciousness. Elite Hindus took advantage of the situation much earlier than the Muslims. However, towards the end of the nineteenth century, Muslims were extremely vocal in their demand for English education. Muslims demanded share and place in the Calcutta University, which ensured some sort of social mobility. Batbyal argues that the colonial state created situations, which ensured the growth of communalism. The CongressLeague Pact at Lucknow did not work. After the Act of 1935, the situation became further complicated in Bengal. The injustices against the Muslim community took a universal plane. One community was fighting against another. This idea of opposition further strengthened the feeling of separateness. Moreover, grievances over education further polarized the differences between two communities. $^{260}$

By the early 1940s it was clear that education was no longer a priority for either the colonial state or the Bengali leaders. As a result, education policies during the last phase of colonial rule were affected by the political developments of the period. The war, the bitter struggle for power, and the Pakistan plan had a severe impact on the education system of the province. Schools remained closed for several days, enrollment decreased, and on several occasions the government reduced financial aid to schools. It was assumed that Pakistan would allow Muslims of Bengal freedom from Hindu competition in terms of administration, economy, and politics. The sovereign state of Pakistan would include Muslims of Bengal and Assam. The

\footnotetext{
${ }^{259}$ See Chatterjee, Bengal Divided: Hindu Communalism and Partition 1932-1947, 220- 68.

${ }^{260}$ See Batabyal, Communalism in Bengal, From Famine to Noakhali 1943-47, 67-70.
} 
idea to create Pakistan received support not just from the League but also from Muslim youth and masses. ${ }^{261}$

The "Purba-Pakistan" (East Pakistan) Renaissance Society in Calcutta and the Purba Pakistan Sahitya Samity (East Pakistan Literary Society) were established to give a cultural shape to the idea of Pakistan. They made an effort to develop a Muslim national culture by celebrating congregations and cultural functions during Muslim festivals. Eminent Muslim intellectuals such as Fazlur Rahman believed that Pakistan would advance their political and economic interests and help Muslims to develop their own respective culture and literature. At the same time, Muslim students were also vocal in their demand for Pakistan. Calcutta was the center of student politics, the Islamia College and the Becker Hostel were centers of student politics. I. Zuberi, the Principal of the Islamia College, was the leader of the student movement in Calcutta that supported the creation of Pakistan. In the case of Dhaka, Hindu and Muslim students were already divided in their approach to the Pakistan movement. Muslim students and the youth of Dhaka started the Muslim students' party, which was part of the Nawab family. Public meetings and conferences convinced that Muslim supremacy could be achieved in Pakistan, which was denied by the narrowness of the Hindu mind and society. ${ }^{262}$

Gradually towards the end of colonial rule, both Hindu and Muslim students were drawn into partition politics. Leaders successfully mobilized students to support their cause. For example, the All Bengal Muslim Students League and the Muslim National Guard acquired a new momentum and tried to spread the message of Jinnah in the countryside. Jinnah indicated that Jawaharlal Nehru wanted a united India but was not sure how to maintain harmony among

\footnotetext{
${ }^{261}$ See Sen, Muslim Politics in Bengal 1937-1947, 178-80.

${ }^{262}$ Ibid., 178-9.
} 
Hindus and Muslims. The Congress and other Hindu organizations wanted to destroy the scheme of Pakistan, nationalize the cabinet, and keep Muslims in a minority position. He urged Muslims of Bengal to unite under the banner of the Muslim League and oppose any form of persecution and oppression. Unfortunately neither the British nor the Bengali leaders were any more concerned about a stable education policy. Everybody wanted a separate state for Muslims, but they overlooked the everyday problems of the general Indians. As a result of which the government restricted new faculty appointments. The fact that universities were used for military purpose and this restricted the actual admission of students. The Fazlul Huq and Salimullah Muslim halls were used to shelter students during and after the war. Education or any other nation building projects were no more a priority for the leaders including Jinnah. ${ }^{263}$

Middle class students, both in urban and rural areas also participated in the movement. This was evident from the fact that the number of students at the Dhaka University in 1942 decreased from 1,633 to 1,408. The government decreased financial aid, and several plans to develop the university such as introduction of the Engineering Department were dropped. They refused to appoint a reader and the proposal to construct another Fazlul Huq Hall did not materialize. $^{264}$

Along with Bengal, Muslim students in different parts of the country were also mobilized to support the Pakistan plan. For example, Mr. Nusrat Hasan, the Vice-President of the Aligarh University Union, supported scheme for Pakistan. He indicated that the League would soon introduce economic and educational programs for Muslims of India that would help Muslims to struggle for Pakistan. Jinnah in his speech suggested that according to the current

\footnotetext{
${ }^{263}$ BL Government of Bengal, University of Dacca, Annual Report, 1943-44 \& 1944-45, Mss Eur 221/78; M.A. Jinnah, Speech at Bengal Provincial Muslim league Conference, 1942

${ }^{264}$ BL, Government of Bengal, University of Dacca Annual Report, 1941-42, Mss Eur 221/79.
} 
constitution, Hindus and Muslims should have had equal share in the center and provinces. But the British government failed to address the needs of Muslims and Gandhi was fighting for a constitution, where they were a minority. Jinnah constantly emphasized that Pakistan would help Muslims to prosper, which was practically impossible in India. ${ }^{265}$

As the political situation intensified, there were riots all over Bengal. The League considered the Congress their enemy and used terror tactics to suppress their opposition. NonLeague and nationalist Muslims were constantly attacked. The demand for a separate Muslim state strengthened. Jinnah strongly believed that in a separate nation there will be no riots over cow sacrifice, education will become simple and less expensive; the executive will be strong and honest; and politics will be free from animosity and rancor. The Muslim community will be free from fear and anxiety. According to Jinnah, Muslim India was not against Hindustan, it stood with Hindustan to fight against the hostile power. ${ }^{266}$

Years of grievances over education policies was instigating one community to fight against the other. At the same time, political instability had a tremendous impact on education policies during the final stages of colonial rule. There was a recurring decrease in the number of students at the Dhaka University because of these communal disturbances. Communal disturbances affected the normal life of the Dhaka University and it was used for military purpose. In this uncertain complicated situation, educational institutions and policies suffered immensely. In 1946-47, the entire province had just 13,772 primary schools as against 62,1350 in 1935-36. This increased to 13,950 immediately after independence. During the last few years before independence, number of students in primary schools also decreased. The situation was

\footnotetext{
${ }^{265}$ M.A. Jinnah, Pakistan, The Muslim Charter (Aligarh: Muslim University Union, 1943), 1-14

${ }^{266}$ See Sen, Muslim Politics in Bengal 1937-1947, 177-8. S.P. Kulyer, letter to the editor, Behar Herald (1942): 79.
} 
similar in the case of middle and higher education. Towards the end of colonial rule, education policies no longer remained a concern for the politicians or the colonial state. Communal riots, independence, and partition plans dominated the situation. ${ }^{267}$

At the beginning of the twentieth century, a section of the Muslim community supported separate educational institutions and electorates in the hope that it improved their social status. But there were Muslim intellectuals who opposed such demands. They feared that separate institutions would complicate the communal situation of the province. But even after the establishment of separate institutions education for Muslims was always a problem. Except for the Dhaka University, most of the institutions were located in West Bengal, which forced Muslim students to live in Calcutta. Institutions in Calcutta did not include Muslim students, textbooks were not suitable and they had limited accommodation in the city. However, intellectuals such as Fazlul Huq tried to improve the status of Muslim education by reserving seats for Muslims in educational institutions. Huq also increased Muslim representation at local level. In a colonial society, both Hindus and Muslims were always trying to secure a better position. In this situation, intense competition continued to aggravate the differences between the two communities. Finally after the Second World War and the elections of 1945-46, Muslim League represented Bengali Muslims and also the face of Muslim communalism. The All India Muslim League opposed the demand of the Congress to launch an open rebellion by organizing mass civil-disobedience. Jinnah urged Muslims to stay away from the movement, as it

\footnotetext{
${ }^{267}$ See Batabyal, Communalism in Bengal, From Famine to Noakhali 1943-47, 212-6; BL, Government of West Bengal, Report on Public Instruction in West Bengal 1947-48, IOR V/24/989.
} 
jeopardized their interests and forced the government to surrender to the Congress and accept their demands. ${ }^{268}$

During the last phase of colonial rule, partition politics and the constant conflict between the state and the Indian leaders dominated the political and social situation of the province. Muslims were made to believe that Pakistan would improve their social situation in terms of education, employment, and life. This propaganda solidified the belief that the state of Pakistan would save Muslims from Hindu tyrants after independence. Education policies were no longer important towards the end of colonial rule but the repeated failure to secure a significant position under colonial rule communalized the society. Separate educational institutions, electorates and finally communalism changed the social fabric of India. Hence the demand for a separate nation was the outcome of the communal division of the country.

\section{Conclusion}

In terms of education, there was also a deep division within the Muslim society over separate educational institutions. Moreover these institutions were beyond the financial capacities of rural Muslims. Dhirendra Nath Dutta indicated that Huq extended education to illiterate Muslims and made sincere efforts to spread knowledge and enlightenment among Muslims in Bengal. But he never openly opposed the need for a separate nation and his support for the Secondary Education Bill of 1940 further complicated the communal situation of the province. Furthermore, his policy to reserve seats for Muslims in government jobs and educational institutions intensified the differences between Hindus and Muslims. Universal free primary education was not introduced and most records indicate that after he was removed from

\footnotetext{
${ }^{268}$ See Sen, Muslim Politics in Bengal 1937-1947, 138-9; See Batabyal, Communalism in Bengal, From Famine to Noakhali 1943-47, 382-3.
} 
his post the Bengal Government neglected nation-building projects. The agitation over separate schools, communal textbooks, universal primary education, and the Secondary Education Bill strengthened the imagination about Pakistan for both Hindus and Muslims. ${ }^{269}$

A.G. Noorani argues that even after independence from British, the social position of Muslims did not change in India. They continued to experience discrimination and hostility in their daily lives. In 1947 Muslims found themselves leaderless and hence they took wrong political decisions in 1948-49. Indian leaders found themselves ineffective in secular parties and Noorani indicated that Muslims did not actively participate in national politics and the secular parties also did not help them to eradicate their grievances. Constitutional safeguards during colonial rule were extremely inadequate and did not improve immediately after Partition. According to Noorani, Partition did not improve the social status of Muslims, rather aggravated it. $^{270}$

After independence, Muslim education continued to be a problem for the Indian ministers. The Aligarh Muslim University was accused of pro-Pakistan activities and for recruiting doctors and engineers for Pakistan. In 1968, Jayaprakash Narayan, the social reformer and activist, at the Convocation address of the Aligarh Muslim University remarked, "The hangover in the minds of Indian Muslims from the days of the two nation theory and the psychological reaction to the militant Hindu rashtra (nation) movement place the Muslims in a most difficult situation." (Noorani, 359) Lastly in 1999, Mr. Justice A.M. Ahmadi, indicated that Muslim enrollment in schools was 62 percent less than the Hindu majority. Muslims held just two percent of the government jobs and received less than four percent of the fund distributed in

\footnotetext{
${ }^{269}$ Dhirendranath Dutta, “As I have seen Fazlul Huq,” in Shere Bangla Juge Juge, ed. Azizul Huque Shahjahan e.. (Dhaka: Shere Bangla Research Center, 1981), 114-6.

270 A.G. Noorani, ed. The Muslims of India: A Documentary Record (New Delhi: Oxford University Press, 2003), 1-
} 3. 
1970s and 1980s. Moreover, after the Babri Masjid demolition, hatred against Muslims increased, which affected the employment scenario for Muslims. Government funds did not reach the Muslim community for education. The communally polarized situation hasn't changed even today. ${ }^{271}$

${ }^{271}$ Ibid., 285-7. 


\section{Final Conclusion}

The dissertation brings to light the development of complicated education policies in colonial Bengal. By chronologically organizing the dissertation, I evaluated how the introduction of English brought about significant shift in social relations. The knowledge of English was necessary to secure any form of employment under colonial rule. A section of the Hindu community accepted new ideas as it helped them to advance under colonial rule. Moreover, the Charles Wood's Despatch of 1854 popularized English over the vernacular languages of the country. This situation helped higher caste and class Hindus to progress. Bhadraloks deprived Muslims and lower caste Hindus of the benefits of education. However, educated Hindus also opposed the study of English and Western literature. But the demand for English education was far stronger than the opposition. Moreover, the despatch also introduced a system of publicprivate partnership in education where Indians were required to pay fees in order to secure education. This had a significant impact on the Muslim community. Muslims received support from the state for their education during the Mughal period. But under colonial rule, Muslims had to pay fees to attend educational institutions, which was beyond the financial capacities of the majority of the community. Along with fees, there was no support from the colonial state for the study of Arabic and Persian, which were essential for the Muslim community. Although the Wood's Despatch aimed to spread mass education, it continued to increase inequality in the society. The recommendations of the despatch favored only a section of the Hindu community. A similar situation would be noticed within the Muslim community towards the end of the nineteenth century under the leadership of Nawab Bahadur Abdul Latif. 
Abdul Latif played an important role in changing Muslim approach towards the British. He urged the community to study English as it helped them to secure employment. He also demanded separate schools for Muslims. In a colonial society, Muslims wanted separate schools as it allowed them to study both English and Persian. Also in separate schools they didn't have to compete with Hindus for scholarships. However, the separate educational institutions did not always help Muslims to progress as they suffered from financial crisis or depended on private support. Moreover, Muslim students opposed separate institutions as they were afraid that it might aggravate the communal situation. This dissertation reveals that the Muslim community demanded separate educational institutions in the hope that it would improve their position in the colonial society. The constant failure to secure more benefits for their community motivated them to support separate electorates and institutions. They wanted to secure a permanent position after Indian independence, as Hindus opposed any benefits awarded to Muslims by the British. However, Latif was extremely conscious of his class and was reluctant to extend English education to the Muslim masses. In fact most Muslim intellectuals demanded religious education for the masses as it decreased competition over government jobs. Religious education mobilized the Muslim masses to support separate educational institutions. However, as a result of the changing approach towards Western knowledge, there was an overall improvement in Muslim education. Enrollment in primary and high schools increased but remained a problem for higher education. Lastly, the decrease in state support for vernacular education forced rural and poor Muslims to leave their education. Towards, the end of the nineteenth century, Muslims realized the significance of English and was willing to study the language. But limited opportunities in the colonial society resulted in unequal development within the Muslim community and also increased the differences between Hindus and Muslims. ${ }^{272}$

${ }^{272}$ See Ahmed, The Bengal Muslims 1871 -1906: A Quest for Identity, 184-90 \& 228-38. 
This dissertation not just explores the complexities of the colonial education policies but also shows the transition from the nineteenth to the twentieth century. In the twentieth century, the government was moving more towards privatization of education. The number of aided and private schools increased. There was no support for the study of vernacular languages and the reformed madrassah policy replaced Persian with English in the madrassahs. As a result, there was a significant increase in the overall number of educated Muslims but there was no scope to pursue just the study of vernacular languages. Moreover, with the rise of the national movement, the division between Hindus and Muslims increased. A section of the Muslim community demanded the establishment of the Dhaka University as it helped Muslims to progress. But this dissertation also brings out the voices of dissent. For example, Hindu and Muslim students of the Dhaka University expressed their discontent over the communal nature of the education policies. They opposed the system of separate schools, which they believed created rift between the two communities. However, after the swadeshi movement (1905-1910) and the annulment of Partition of Bengal in 1911, a section of the Muslim leadership, students, and preachers turned against the British rule. They expressed their grievances over the shortage of scholarships, educational institutions, and financial aid. Along with colonial policies, they feared Hindu imperialism and this motivated them to support the demand for Pakistan. Authoritarian nature of the colonial state helped the community to solidify their Islamic beliefs.

Throughout the 1920s and 1930s the division between the communities further increased over education policies. The demand for separate educational policies was influenced by the contemporary political situation, which became worse towards the end of colonial rule. Fazlul Huq tried to improve the educational situation of the province by reserving seats for Muslims. But towards the end of colonial rule, Muslim leaders turned towards their faith to justify their 
need for a separate nation. However, not all Muslims supported the demand for Pakistan but the subsequent failure of colonial policies and inability to protect them from Hindus culminated in Pakistan. It was believed that Pakistan as a nation would allow Muslims to practice their religion without any fear. It was the best possible solution to the communal and educational problems. ${ }^{273}$ Finally, towards the end of colonial rule, education was no longer important to the colonizers. Conflicts over education policies increased the differences between the two communities, which continue even today. Immediately after independence, India had to educate 360 million people and Jawaharlal Nehru, the first prime minister of independent India, wanted to change the entire education system that existed during the colonial rule. He wanted to provide universal free elementary education, lower the percentage of adult illiteracy, and adopt Indian languages as the medium of instruction. Educationists showed that the number of primary schools all over India increased from 209,671 in $1950-51$ to 500,000 in 1973-74 and the country had over 100 universities and 4000 colleges in 1973 instructing 3.4 million students. However, this increase was not sufficient in comparison to the total population in the 1970s. Inequality existed in education even after independence based on caste and religion. ${ }^{274}$

Along with caste and religion, the medium of instruction continued to remain a problem for the newly independent South Asian countries. English was considered the most important language in India. Each of the countries proposed a 15 year period of transition to an education system based on national language. It did not work in any of the countries. The Bengalis of East Pakistan opposed the use of Urdu as the medium of instruction. Similarly, there were riots in India between Hindi and non-Hindi speaking people of South India. However, by 1990 elite Indians were able to secure several years of English education in school. In the recent

\footnotetext{
273 Suchetana Chattopadhyay, “Jihad at Wartime?” South Asian History and Culture (March 2016) 154-74.

${ }^{274}$ Dr. A.R. Kamat, Education After Independence: A Social Analysis (Bombay: Lala Lajpatrai Institute, 1973-74), 14-25.
} 
years middle class children are also able to secure English education. David Northrup argues that the knowledge of English allows children from less privilege background to progress. Moreover, the middle class in developing countries have actually helped in the spread of English. A similar situation existed in colonial Bengal. The British introduced English, which was the language of power and prestige. Elite and middle class Hindus had to learn English because the knowledge of English was necessary to secure government employment. However, the Muslim failure to adjust with this new language had a drastic impact on the community. But, over time as elite Muslims realized the need for English, they deprived the rural masses from English education to decrease competition in government jobs and employment. The knowledge of English marginalized vernacular languages in colonies and created a sense of class consciousness. ${ }^{275}$ Education remained a debatable issue in India even after independence. The struggle still continues to transcend complexities related to caste and religion.

${ }^{275}$ David Northrup, How English Became the Global Language (New York: Palgrave Macmillan, 2013), 84. 


\section{Appendix}

Enrollment (\%) of Muslim students in madrasshs from 1881 to 1922

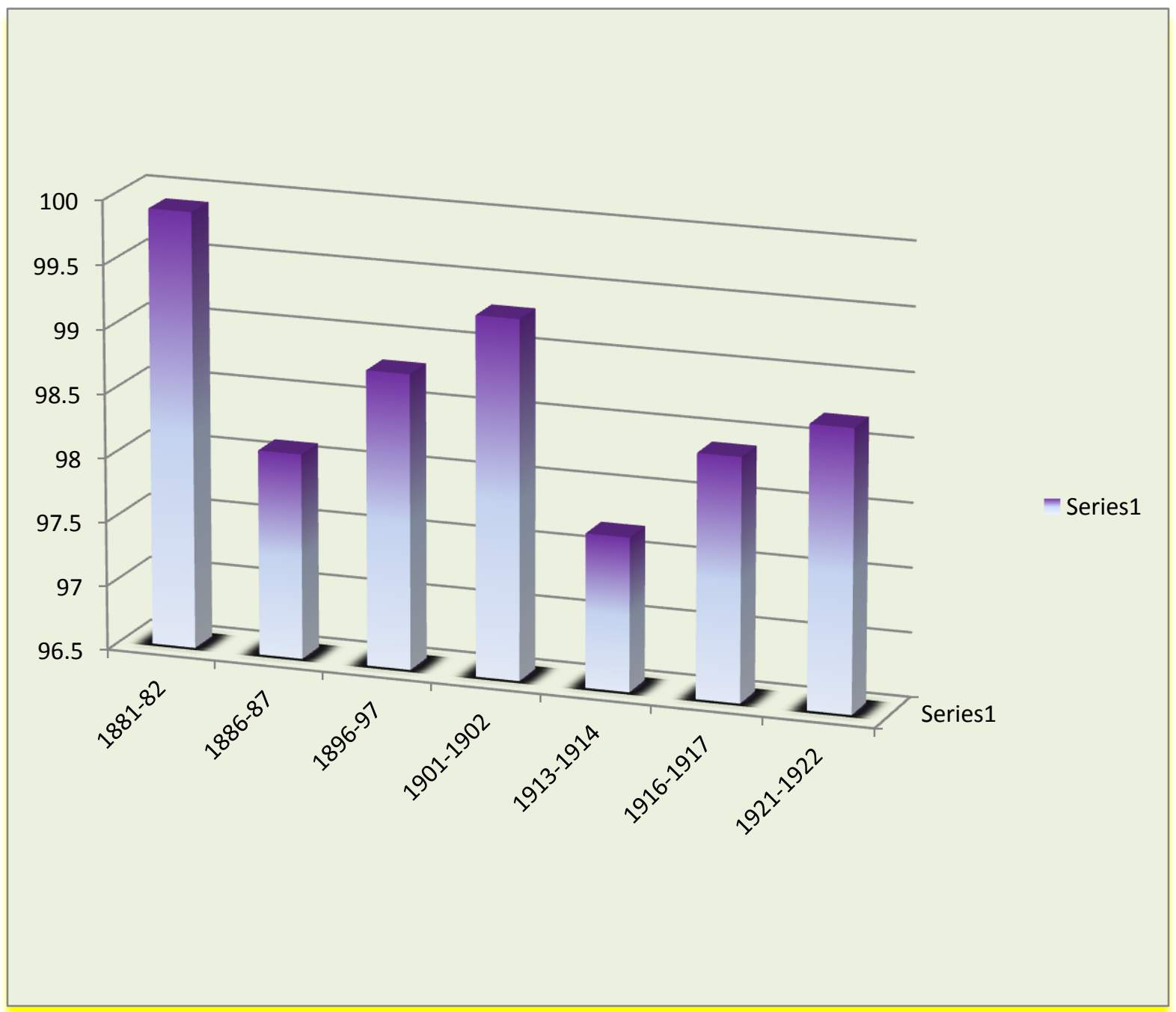

Source: British Library, Government of Bengal, Report of the Director of Public Instruction for Bengal, 1934-35, 1935-36, 1938-1939, IOR V/11/806.

Mohammad Shah, In Search of an Identity: Bengali Muslims 1880-1940 (Calcutta: K.P.Bagchi \& Company, 1996), 112-5. 
Enrollment (\%) Muslim students in primary schools from 1881-1938

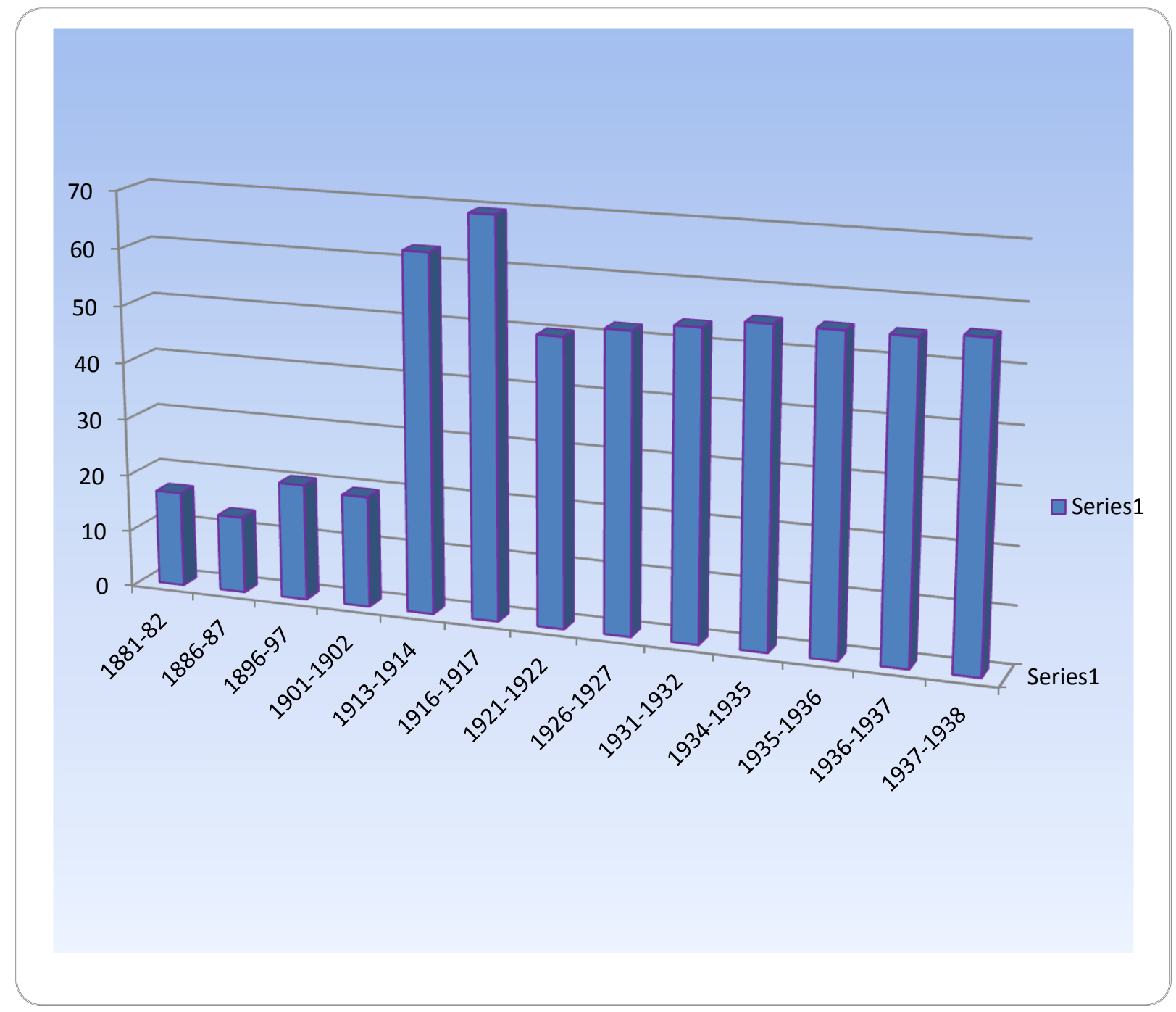

Source: British Library, Government of Bengal, Report of the Director of Public Instruction for Bengal, 1934-35, 1935-36, 1938-1939, IOR V/11/806.

Mohammad Shah, In Search of an Identity: Bengali Muslims 1880-1940 (Calcutta: K.P.Bagchi \& Company, 1996), 112-5. 


\section{Enrollment(\%) of Muslim Students in Arts colleges from 1881 to 1938}

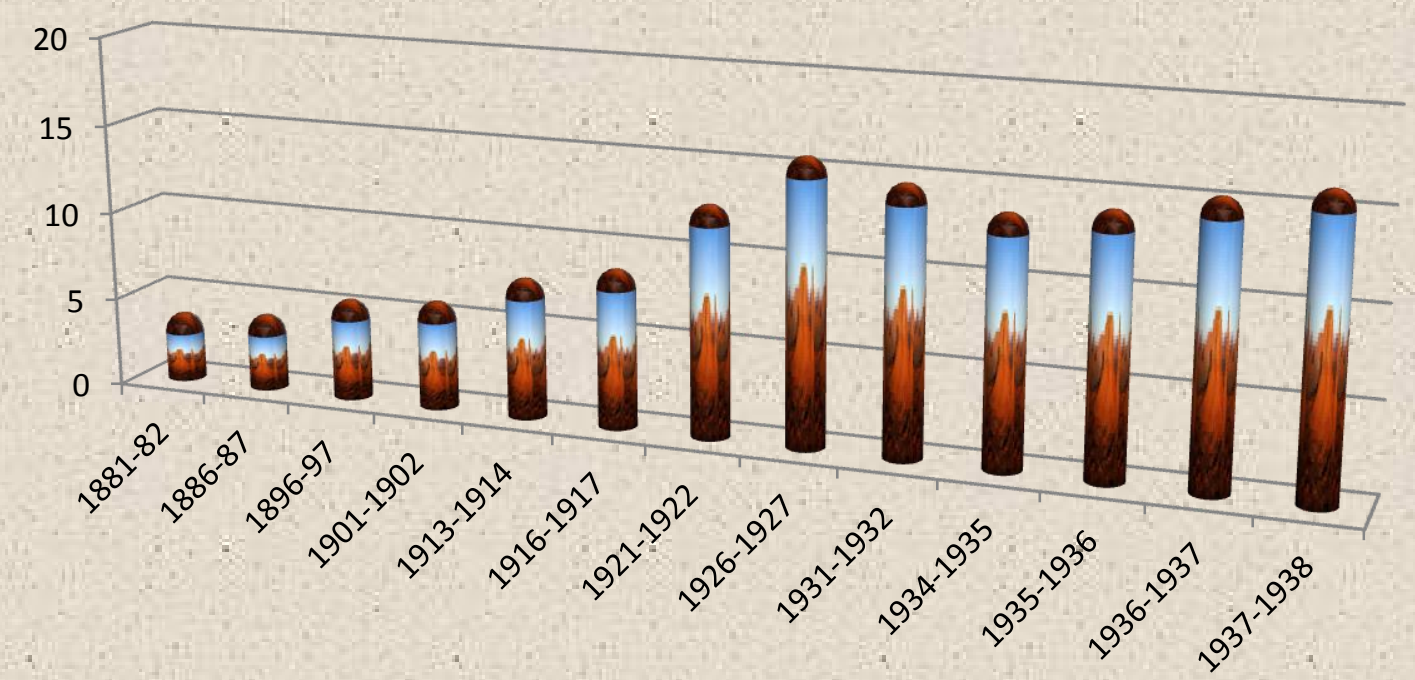

Source: British Library, Government of Bengal, Report of the Director of Public Instruction for Bengal, 1934-35, 1935-36, 1938-1939, IOR V/11/806.

Mohammad Shah, In Search of an Identity: Bengali Muslims 1880-1940 (Calcutta: K.P.Bagchi \& Company, 1996), 112-5. 


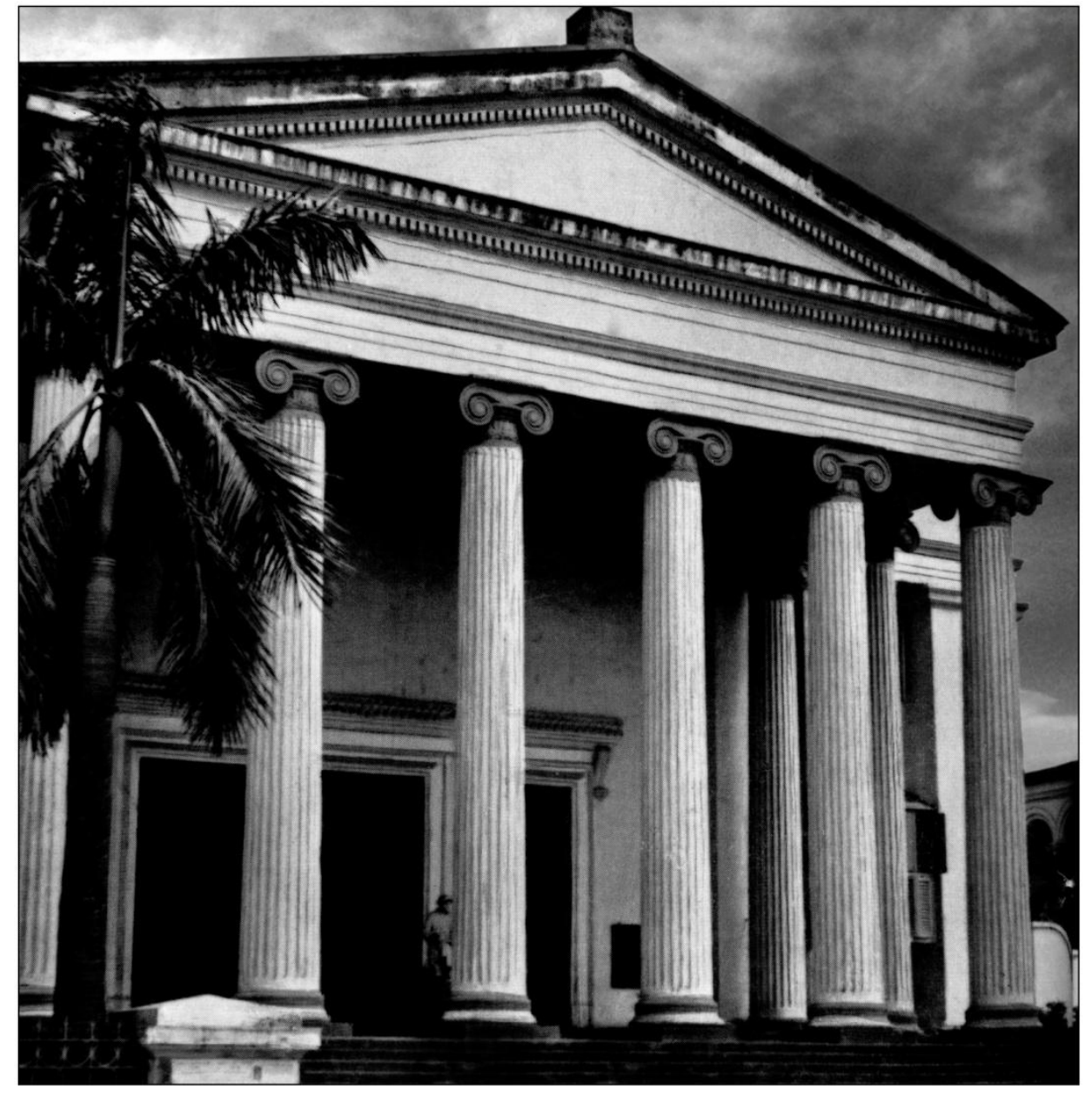

The Senate Hall. Front view

Source: Historic Photos from the Calcutta University Collection 


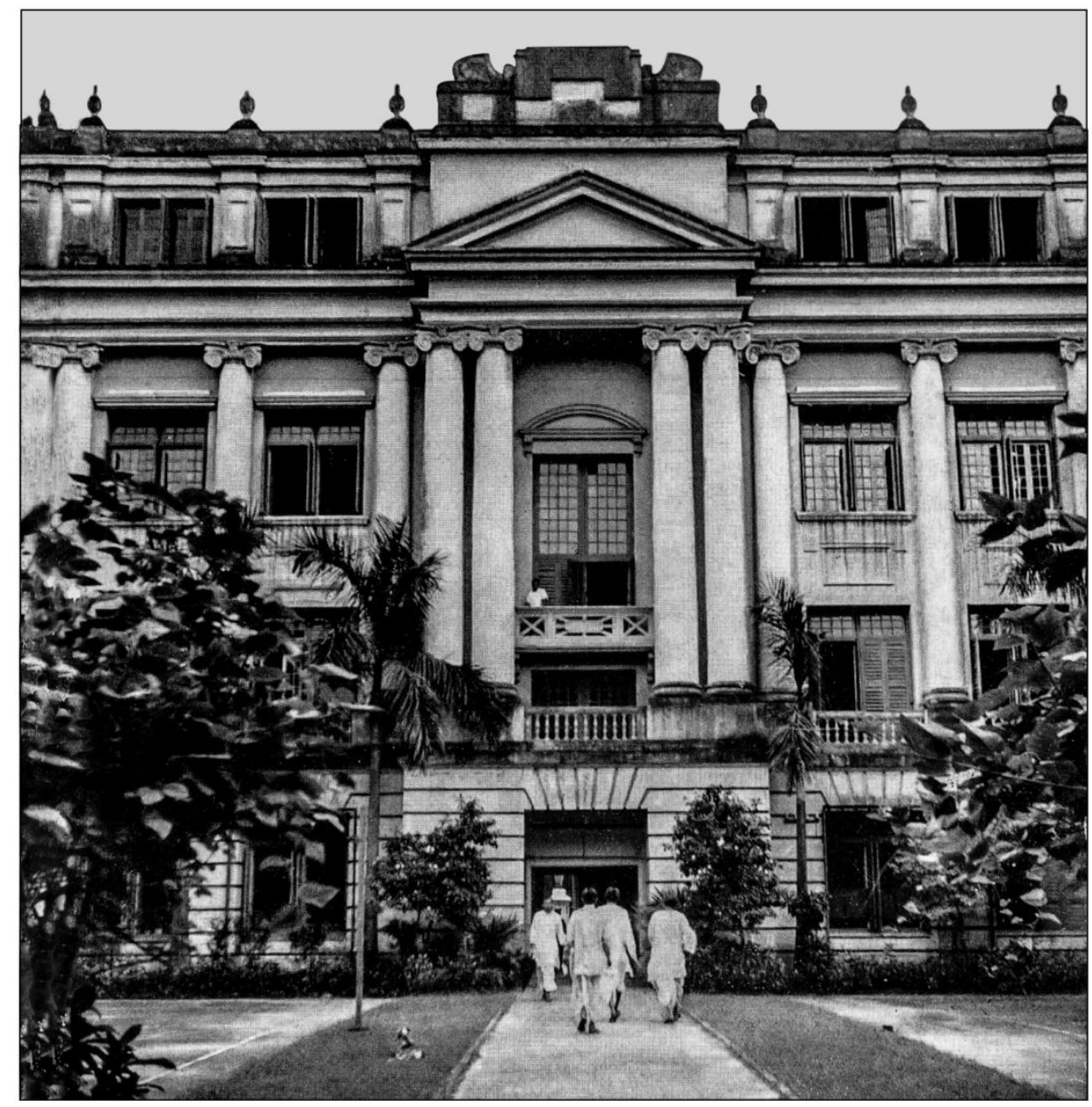

The Asutosh Building which is the seat of the College of Arts, the College of Commerce and the Central Library

Source: Historic Photos from the Calcutta University Collection 


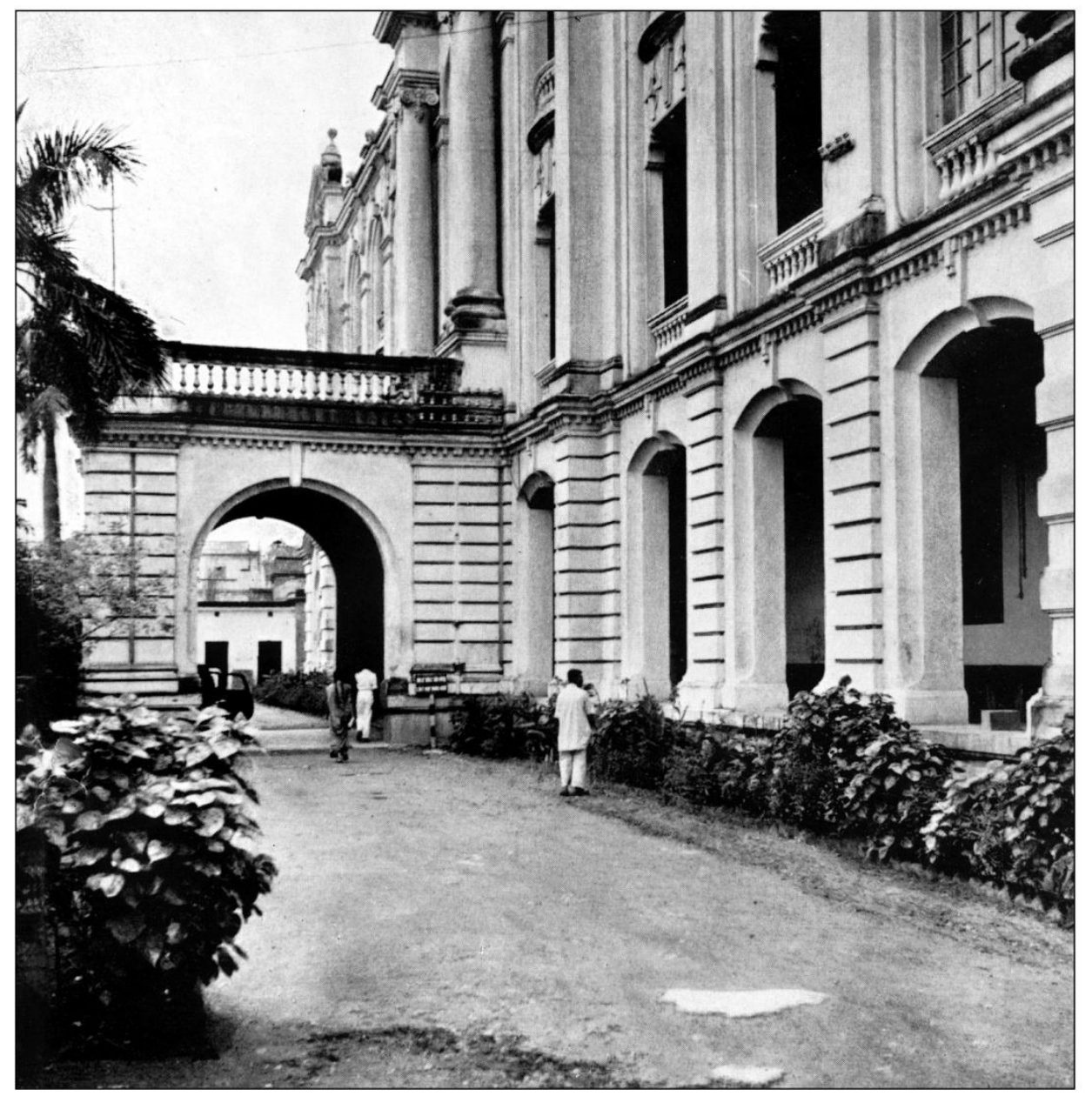

University College of Science and Technology. Main Entrance.

Source: Historic Photos from the Calcutta University Collection 


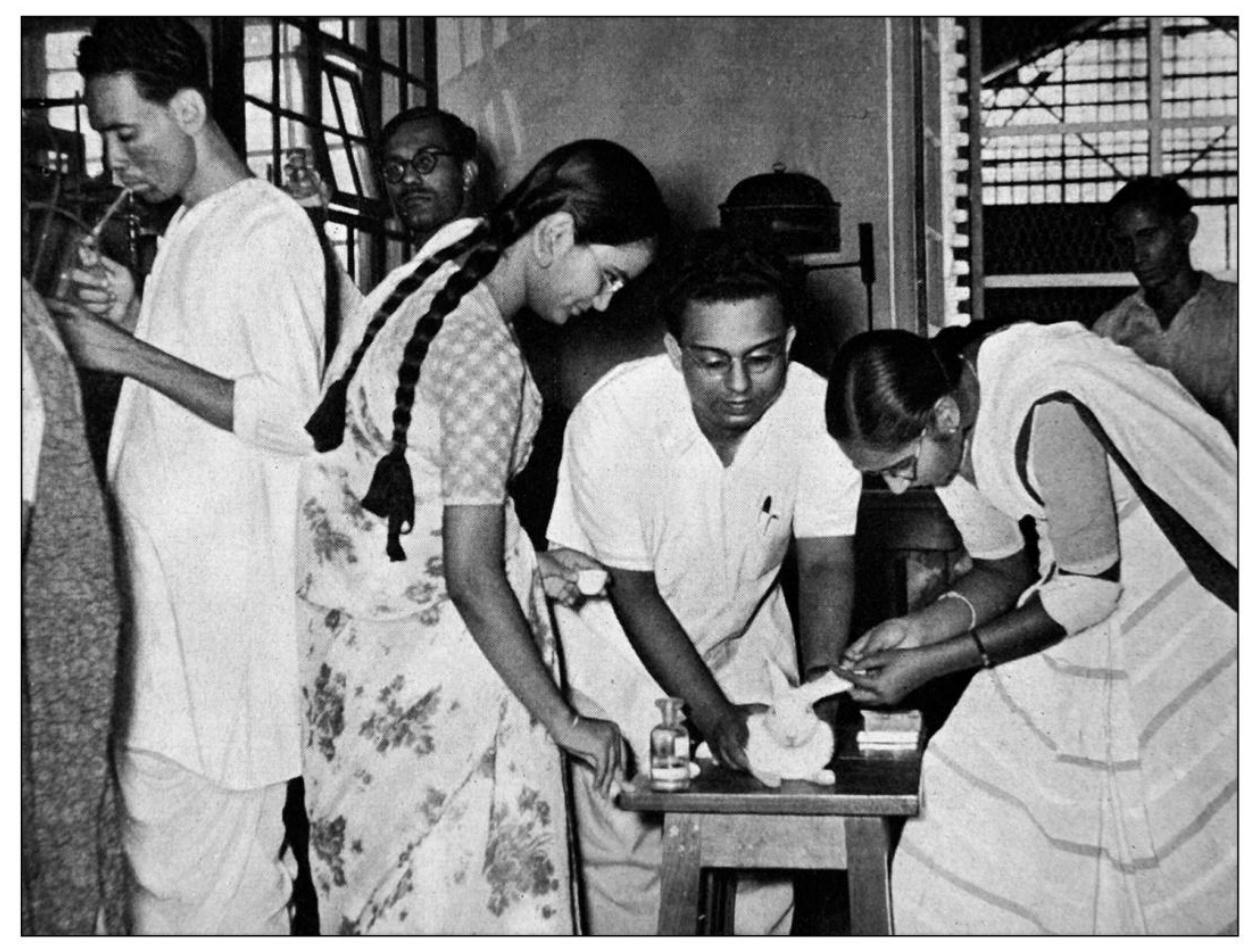

Physiology : A Biochemistry class in session

Source: Historic Photos from the Calcutta University Collection 


\section{Bibliography}

\section{Primary Sources}

Archives and Libraries as referenced in the footnotes

British Library, London (BL)

University of Dhaka Annual Reports

Dhaka University Journals

European Manuscripts

National Library, Kolkata (NL)

Bengal Legislative Assembly Proceedings (Selected Years)

National Archives of India, New Delhi (NAI)

Proceedings of the Government of Bengal (Selected Years)

Census of India (1921 and 1931)

West Bengal State Archives, Kolkata (WBSA)

Proceedings of the Government of Bengal (Selected Years)

\section{Non Official Records}

\section{Periodicals/Newspapers in English}

Behar Herald

Daily Hitavadi

Hanifi

Moslem Chronicle

Mussalman

Nihar

Sanjivani

Sandhya 
Soltan

\section{Periodicals/Newspapers in Bengali}

Al-Islam

Amrita Bazaar Patrika

Ananda Bazar Patrika

Choltan

Dainik Bangla

Dhumketur Pathe

Islam Darshan

Islam Procharak

Langal

Nabanur

Saogat

\section{Published Primary Sources}

Ahmad, M.M. Present Day Problems of Indian Education: With Special Reference to Muslim Education. Bombay: B.N.Kapadia at the Fine Art Press, 1935.

Ahmed, Muzzafar." Arabi Bhasha" Bangiya Muslim Sahitya Patrika (October 1919) 232-5.

Hunter, W.W. The Indian Mussalmans. Varanasi: Indological Book House, 1871.

Huq, A.K. Fazlul. Bengal Today. Calcutta: Gupta Rahman and Gupta, 1944.

Huque, M. Azizul, History and Problems of Moslem Education in Bengal. Calcutta: Thacker Spink \& Co, 1917.

Huque, Enamuel. Nawab Bahadur Abdul Latif: His Writings \& Related Documents. Dacca: Samudra Parakshani, 1968.

Kabir, Humayun. Muslim Politics 1906 -1942. Calcutta: Gupta Rahman \& Gupta, 1944 
Karim, Abdul. Presidential Address Delivered at the Session of the All India Muslim League, Held at Aligarh in 1925. Calcutta: Karim Bux Brothers Printers: 1925.

Islam, Mustafa Nurul. Bangali Muslim Sampadito Samayik Patra. Dhaka: Jahangir University Press, 1977.

Jinnah, M.A. Pakistan, The Muslim Charter Aligarh: Muslim University Union, 1943.

Johnston, Rev James. Our Education Policy in India: A Vital Question for the Government and the Church. Edinburgh: John Maclaren \& Son, 1879.

Monteath, Alexander. \& Holwell, Arthur Pearse. Selections from Educational Records of the Government of India, Educational Reports 1859-1871, ed. New Delhi: National Archives of India, 1960.

Pincott, Fredric. "Popular Education in Bengal," St James Magazine, (November 1862), 483-79

Richley, A. ed. Selections from Educational Records 1840-1859. Calcutta: Superintendant Government Printing, 1922.

Riseley, H.H. and Gait, E.A. Census of India, 1901 Calcutta: Office of the Superintendent Government Printing, 1903.

Shahjahan, Azizul Huque, Shere Bangla Juge Juge. Dhaka: Shere Bangla Research Center, 1981.

\section{Secondary Sources}

\section{Journal Articles}

Archarya, Poromesh. "Education and Communal Politics in Bengal." Economic and Political Weekly (1989), 81-90.

Chattopadhyay, Suchetana, "Jihad at Wartime?" South Asian History and Culture (March 2016): 154-74.

Rahman, Aminur "The Political Economy of English education in Muslim Bengal: 1871-1912." Comparative Education Review (August 1992): 309-321.

Roy, Madhumita, "Englishing India, Reinstituting Class and Social Privilege." Social Text (Summer 1994): 83-109. 


\section{Books}

Acharya, Srikumar. The Changing Pattern of Education in early Nineteenth century Bengal. Kolkata: Punthi Pustak, 1992.

Ahmed, Rafiuddin. The Bengal Muslims 1871-1906: A Quest for Identity. Delhi: Oxford University Press, 1981.

Ahmed, Sufia. Muslim Community in Bengal 1884 -1912. Dacca: Oxford University Press, 1974.

Batabyal, Rakesh. Communalism in Bengal, From Famine to Noakhali 1943-47. New Delhi: Sage Publications India Pvt Ltd, 2005.

Broomfield, J.H. Elite Conflict in a Plural Society: Twentieth Century Bengal. Berkeley: University of California Press, 1968.

Chatterjee, Jaya. Bengal Divided: Hindu communalism and Partition, 1932-1947. New Delhi: Cambridge University Press, 1995.

Das, Suranjan. Communal Riots in Bengal 1905 -1947. New Delhi: Oxford University Press, 1991.

De, Dhurjati Prasad. Bengal Muslims in Search of Social Identity. Dhaka: The University Press Limited, 1998.

Eaton, Richard. The Rise of Islam and the Bengal Frontier, 1204 -1760. Berkeley: University of California Press, 1993.

Ghosh, Suresh Chandra. The History of Education in Modern India 1757-2007. Delhi: Orient Blackswan Private Limited, 1995.

Hardy, Peter. The Muslims of British India. Great Britain: Cambridge University Press, 1972.

Hasan, Mushirul. ed. Communal and Pan-Islamic Trends in Colonial India. New Delhi: Manohar Publications, 1981.

Haque, Ishrat. Glimpses of Mughal Society and Culture-A Study Based on Urdu Literature: in the $2^{\text {nd }}$ Half of the $18^{\text {th }}$ Century. New Delhi: Concept Publishing Company, 1992.

Husain, Abid S. The Destiny of Indian Muslims. Bombay: Asia Publishing House, 1965.

Jalal, Ayesha. The Sole Spokesman: Jinnah, the Muslim League and the Demand for Pakistan. Cambridge: Cambridge University Press, 1985.

Kamal, Kazi. Ahmed. A.Z. Fazlul Huq, Suhrawardy, and Maulana Bhashani: An Intimate Study of Politicians and Inside Stories. Dhaka: A.H. Development Publishing House. 
Kamat, A.R. Education After Independence: A Social Analysis. Bombay: Lala Lajpatrai Institute, 1973-74.

Kanda, K.C. Masterpieces of Patriotic Urdu Poetry: Texts, Translations, and Transliteration New Delhi: Sterling Publishers Private Limited, 2005.

Kaura, Uma. Muslims and Indian Nationalism: The Emergence of the Demand for India's Partition 1928-1940. New Delhi: Manohar Book Service, 1977.

Khan, Muin-ud-Din Ahmed. Muslim Struggle for Freedom in Bengal. Dhaka: Islamic Foundation Bangladesh, 1960.

Khan, Yasmin. The Great Partition: The Making of India and Pakistan. New Haven: Yale University Press, 2007.

McGuire, John. The Making of the Colonial Mind: A Quantitative Study of the Bhadralok in Calcutta, 1857-1885. Canberra: Australian National University, 1983.

Metcalfe, Thomas. Aftermath of the Revolt, India 1850-1870. Princeton: Princeton University Press, 1964.

Northrup, David. How English Became the Global Language. New York: Palgrave Macmillan, 2013.

Rahman, Fazlur. The Bengali Muslims and English Education 1765-1835. Dhaka: Bengali Academy, 1973.

Rashid, O. Harun. The Foreshadowing of Bangladesh: Bengal Muslim League and Muslim Politics 1936-1947. Dhaka: Asiatic Society of Bangladesh, 1987.

Raychaudhuri, Tapan. Europe Reconsidered: Perceptions of the West in Nineteenth century Bengal. New Delhi: Oxford University Press.

Ray, Rajat. Urban Roots of Indian Nationalism: Pressure Groups and Conflict of Interests in Calcutta City Politics, 1875-1939. New Delhi: Vikas Publishing House Pvt Ltd, 1979.

Rich, Eric. E. The Education Act of 1870: A Study of Public Opinion. London: Longmans, 1970.

Sanaullah, Mohammad. A.K. Fazlul Huq: Portrait of a Leader. Bangladesh: Homeland Press and Publication, 1995.

Sarkar, Chandiprasad. The Bengali Muslims: A Study in their Politicization 1912-1929. Calcutta: K.P.Bagchi \& Company, 1991. 
Sarkar, Sumit. Swadeshi Movement in Bengal 1903-1908. New Delhi: People's Publishing House, 1973.

------------Modern India 1885-1947. New Delhi: Macmillan India Ltd, 1983.

-Popular Movements and Middle Class Leadership in Late Colonial India:

Perspectives and Problems of a History From Below. Calcutta: K.P.Bagchi, 1983.

-A Critique of Colonial India. Calcutta: Papyrus: 1985.

Sengupta, Parna. Pedagogy for Religion: Missionary Education and the Self Fashioning of Hindus and Muslims in Bengal. Berkeley: University of California Press, 2011.

Sen, Shila. Muslim Politics in Bengal 1937-1947. New Delhi: Implex India 1976.

Shah, Mohammad. In Search of an Identity: Bengali Muslims 1880-1940. Calcutta: K.P.Bagchi \& Company, 1996.

Viswanathan, Gauri. Masks of Conquest: Literary Study and British rule in India. India: Oxford University Press, 1989.

Wolpert, Stanley. A New History of India New Delhi: Oxford University Press, 2009

\section{Bengali Books}

Al-Masum, Mohammad. Abdullah, British Amole Banglar Muslim Sikha: Samasya o Prashar Dhaka: Bangla Academy Press, 2008.

Bandopadhyay, Shibaji. Gopal Rakhal Dandosamas: Uponibeshbad o Bangla Sishu Sahitya Kolkata: Papyrus, 1991.

De, Amalendu. Pakistan Prastab o Fazlul Huq. Kolkata: Ratna Prakashan, 1972

\section{PhD Dissertations}

Abul Kahir Nazmul Karim, "The Modern Muslim Political Elite in Bengal," (PhD diss., London School of Economics 1964)

John Berwick, "Chatrasamaj: the Social and Political Significance of the Student Community in Bengal 1870 -1922,” (Ph.D diss., University of Sydney, 1986)

Suchetana Chattopadhyay, "Muzaffar Ahmad, Calcutta, and Socialist Politics, 1913-1929," (Ph.D diss., University of London, 2004)

\section{Unpublished Papers}

Samar Deen, "Pluralism in $18^{\text {th }}$ century India. Exploring Human Ecological Relations in Urdu Folklore through Nazir Akbarabadi's poems (1740-1830)" 
https://www.academia.edu/8743952/Pluralism_in_18th_century_India_Nazir_Akbar_Abadi, accessed May 17, 2016 